

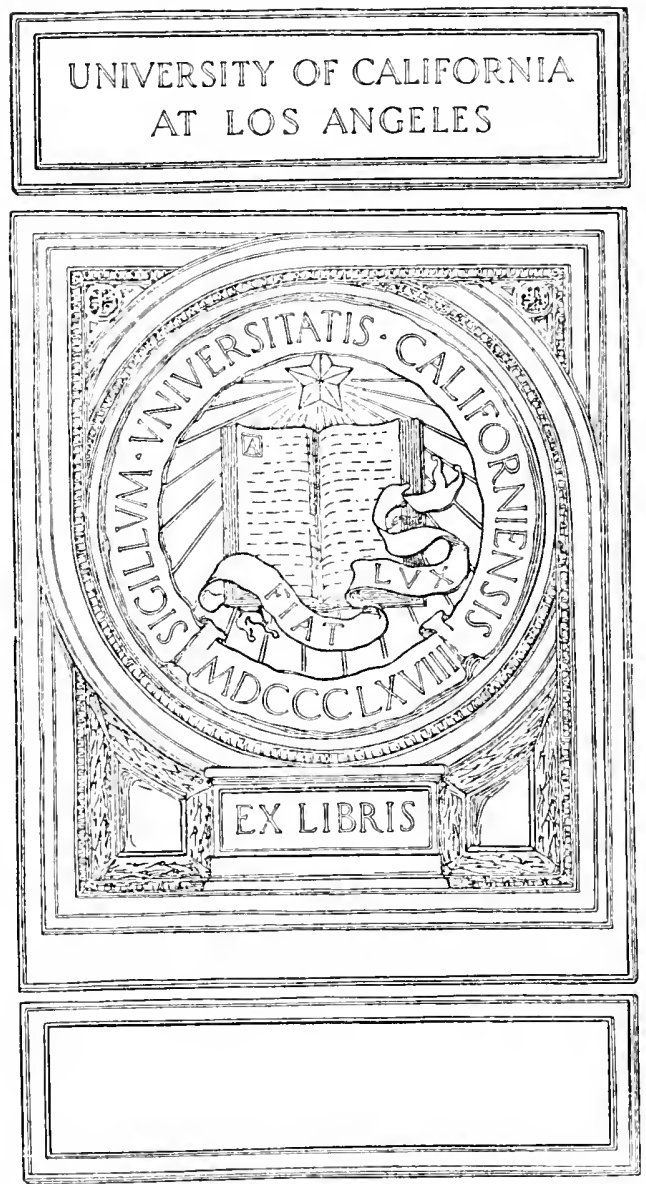
U 
Digitized by the Internet Archive in 2008 with funding from Microsoft Corporation 
FOREIGN EXCHANGE AND FOREIGN BILLS IN THEORY AND IN PRACTICE 


\section{FROM THE SAME PUBLISHERS}

BILLS, CHEQUES AND NOTES. Together with the Bills of Exchange Act, 1882, and the Amending Act, Bills of Exchange (Crossed Cheques) Act, 1906. By J. A. Slater, B.A., LL.B. (Lond.), of the Middle Temple and the North Eastern Circuit, Barristerat-Law ; author of " Commercial Law," "Mercantile Law," etc. Second Edition, revised and enlarged. In demy $8 \mathrm{vo}$, cloth gilt, about $220 \mathrm{pp}$. 5s. net.

HONEY, EXCHANGE, AND BANKING. In Their Practical, Theoretical, and Legal Aspects. By H. T. EAston, Associate of the Institute of Bankers. Second Edition, revised. In demy 8vo, cloth gilt, 312 pp. 5s. net.

BANK ORGANISATION, MANAGEMENT AND ACCOUNTS. By J. F. Davis, D.Lit., M.A., LL.B. (Lond.), Lecturer on Banking and Finance at the City of London College. In demy 8vo, cloth gilt, 165 pp., with many useful forms, 5s. net.

PRACTICAL BANKING. By J. F. G. BAgShaw, Member of the Institute of Bankers. With Chapters on the Principles of Currency, by C. F. HANNAFORD, Associate of the Institute of Bankers, and Bank Book-keeping, by W. H. PEARD, Member of the Institute of Bankers in Ireland. In demy 8vo, cloth gilt, $400 \mathrm{pp}$. 5s. net.

DICTIONARY OF BANKING. A Complete Encyclopaedia of Banking Law and Practice. By W. Thomson, Bank Inspector. With a section on the Irish Land Laws in their relation to Banking, by Lloyd Christian, Secretary to the Institute of Bankers in Ireland. Thoroughly revised and brought up-to-date, August, 1915. In crown 4to, half-leather gilt $563 \mathrm{pp}$. ! 


\title{
FOREIGN EXCHANGE AND FOREIGN BILLS IN THEORY AND IN PRACTICE
}

\author{
BY \\ WILLIAM F. SPALDING
}

CERTIFICATED ASSOCIATE OF THE INSTITUTE OF BANKERS, LONDON ;

FELLOW OF THE ROYAL ECONOMIC SOCIETY;

LECTURER ON FOREIGN EXCHANGE TO THE CITY OF LONDON COLLEGE

SECOND IMPRESSION

\section{LONDON}

Sir Isaac Pitman \& Sons, Ltd., 1 Amen Corner, E.C. Bath, New York and Melbourne 
First Impression, August, 1915

Second

October, 1915

Printed by Sir Isaac Pitman \& Sons, Ltd., London, Batil, NEW YORK AND MELbOURNE 


\section{PREFACE}

THE object of this work is to present in a concise and simple form the theory and practice of Foreign Exchange. At first sight some apology may appear to be due for adding to the already long list of books on this branch of monetary science, but reference to the table of contents will show that special attention has been paid to that more practical part of the subject-foreign bills. The drawing and nego tiation of foreign bills are matters which concern not only

- bankers, but all commercial men, and, bearing this in mind, an endeavour has been made throughout the book to intersperse the practical with the theoretical points.

To explain the working of foreign exchanges in a simple manner is not easy, and the frequent dislocation of the principal exchanges during the war has not conduced to the simplicity of the task. The erratic movements in rates have, however, furnished abundant material from which to draw the necessary illustrations in support of the theories I have tried to make plain.

Exchange with the silver-using countries of the East seems to be a general source of trouble to people dealing with those centres, and in deference to many requests, I have taken the opportunity to include one or two chapters on the Eastern exchanges, which I hope will serve to remove the difficulties which appear to surround this part of the subject.

My thanks are due to the managers and agents of the various foreign and colonial banks in London for much valuable advice and assistance, more particularly, perhaps, to Mr. R. W. Jeans of the Bank of Australasia, Mr. F. S. C. Norman, of the Standard Bank of South Africa, and to my friend, Mr. H. C. Sonne of Denmark.

Government Departments have, as usual, been ready to help wherever possible by facilitating reference to trade 
statistics, and in this respect $I$ am specially indebted to the Right Hon. Sir George H. Reid, P.C., K.C., G.C.M.G. and Mr. G. H. Knibbs of Australia, and to His Excellency, Don Vicente J. Dominguez of the Argentine Republic.

Throughout this book free use, where necessary, has been made of the details contained in the various articles and reviews I have contributed from time to time to the Journal of the Institute of Bankers, the Bankers' Magazine and the Economic Journal, and acknowledgment is hereby made of the courtesy of the respective editors for the consent to utilize such material.

WILLIAM F. SPALDING. 


\section{CONTENTS}

PREFACE

\section{CHAPTER I}

\section{INTRODUCTORY AND EXPLANATORY}

ForEIGN exchange: exaggerated difficulties of the subject: its neglect by the education authorities: the importance of a knowledge of the foreign exchanges"Foreign Exchange" defined : a comparison with the price of wheat-Foreign exchange: the purchase and sale of foreign debts . $. \quad . \quad . \quad . \quad$.

\section{CHAPTER II}

\section{THE BASIS OF FOREIGN EXCHANGE}

WнAт a banker buys when he discounts a bill-The commodities bought and sold in foreign exchange-The purchase and sale of two debts between four traders in different centres-The point at which the real exchange problem arises: foreign trade: the excess of exports over imports-The various forms of international currency .

\section{CHAPTER III}

INTERNATIONAL CURRENCY: THE PAR OF EXCHANGE AND THE MINT PAR OF EXCHANGE, WITH SPECIAL REFERENCE TO AUSTRALIA

THE banker's stock of international currency-The bill of exchange the ideal instrument; but indebtedness can be settled by the remittance of coupons, bonds, etc.-The Mint Par of Exchange : the Ideal or Hypothetical Par-The exchange between Great Britain and Australia: some explanation of Australia's balance of trade-The fixed basis of exchange between Great Britain and other gold-using countries : Chain Rule as a convenient way to calculate the Mint Parity - The Mint Pars of Exchange between England and those countries whose currency is based on gold .

\section{CHAPTER IV}

THE MINT PAR AND GOLD OR SPECIE POINTS IN THEORY AND PRACTICE

The Mint Par necessary as a basis upon which to calculate the worth of a foreign bill of exchange-The 
opposing claims of any two countries rarely balance : the result-Bank bills and trade paper-A divergence between the rules governing the purchase and sale of commodities, and those governing the dealings in debts -Specie points: the banker ultimately responsible for gold shipments-The effect of gold shipmentsLondon a free gold market compared with France, Germany, and America . . . . .

\section{CHAPTER V \\ "FOREIGN EXCHANGE" QUOTATIONS, AND THE " COURSE OF EXCHANGE"}

Foreign exchanges: The Times' table analysed and explained-The reason for a double quotation-Importance of New York's quotations : a specimen tableShort exchange and long exchange: the place of Bank Rate and market rate of discount in the calculations-" The Course of Exchange" : the quotations explained-The reason for two rates for each centre

\section{CHAPTER VI}

CONTINUES THE DISCUSSION ON LONG AND SHORT EXCHANGE AND SHOWS HOW TEL QUEL RATES

\section{ARE CALCULATED}

LoNG exchange: how calculated from the cheque or short rate-One or two of the City Editor's idiosyncrasies explained-In foreign exchange: rates by sweet contraries go . . . . . .

\section{CHAPTER VII}

FAVOURABLE AND UNFAVOURABLE EXCHANGE. THE CAUSES OF THE FLUCTUATIONS IN THE FOREIGN EXCHANGES ANALYSED

WHEN exchange is above par and when below parHow rates are calculated-The signification of the terms "favourable" and "unfavourable"-A rate favourable to the seller of a bill is unfavourable to the buyer-Differences between rates quoted in foreign currency and those quoted in sterling-The difficulties put into rhyme-Fluctuations in the foreign exchanges: their causes-Arbitrage dealings-The Continental demand for bills on London . . . . 


\section{CHAPTER YVIII}

PAGE

BANK RATE AND MARKET RATE OF DISCOUNT IN CONNEXION WITH THE FLUCTUATIONS IN THE

\section{FOREIGN EXCHANGES}

THE importance of the Bank of England Rate-The Gold Reserve: how it is protected-Methods by which the Bank of England obtains control of the marketMarket rates-The inter-connexion of Bank Rate and market rate-How rates are manipulated on the London market when our gold reserve is threatened -The influence on the foreign exchanges: an American view-Movements in the Bank of England's rate compared with those of the French and German rates

\section{CHAPTER IX}

THE MONEY MARKETS OF THE WORLD AND THE GREAT WAR

THE effect of war on the foreign exchanges--Gold movements-The monetary position of the principal financial centres of the world-London in the early days of the war: measures taken by the Government and the banks-A 10 per cent. Bank Rate-Suspension of the Bank Charter Act avoided . . . .

\section{CHAPTER $\mathrm{X}$}

THE FOREIGN EXCHANGES AND THE GREAT WAR

THE complete disorganization of the world's exchanges -Table of rates illustrating the severity of the crisis -French, German, and American exchanges compared -Germany parts with gold-Russian Exchange : reasons for its heavy depreciation, and measures taken to correct the adverse position-New York's desperate plight and the steps she took to rehabilitate exchanges with the U.S.A.

\section{CHAPTER XI}

THE EVIL INFLUENCE OF PAPER CURRENCY ON THE

\section{FOREIGN EXCHANGES}

THE evil of the invention of paper money-The effect of the issue of paper money : the point at which the currency depreciates-The foreign trade of the country is not affeeted, but the foreign exchanges are: this fact explained-The South American States and their excessive issues of paper-The issues of notes during the War: the systems of Great Britain and Germany compared 


\section{CHAPTER XII}

THE EASTERN EXCHANGES

The Gold Exchange Standard as in operation in India and other silver-using countries-Exchange remittances by means of India Council bills and telegraphic transfers-The gold price of silver as the uncertain factor in Eastern commerce-The evils of a silver standard-How exchange in Austria is manipulated -The Philippines and the Gold Exchange Standard -The Gold Exchange Standard in theory and in practice-India's currency position during the war .

\section{CHAPTER XIII}

THE EASTERN EXCHANGES (CONTINUED). CHINA AND THE SILVER PROBLEM

THE unsatisfactory position of Chinese currency-The Chinese tael as a standard of weight and unit of currency-The variations in the value of silver: effect on exporters, capitalists, and investors-The exchange quotations on the Shanghai market-Principles which govern the drawing of bills : disadvantages of a depreciating silver currency-Attempts to state the ratio between gold and silver-The gold price of silver the fundamental basis for fixing the rate of exchange in the East

\section{CHAPTER XIV}

METHODS BY WHICH EXPORTERS ENDEAVOUR TO ELIMINATE EXCHANGE RISKS. EXCHANGE AS PER ENDORSEMENT.

\section{FORWARD EXCHANGE}

THE effect of the clause " exchange as per endorsement " : how the bankers endeavour to fix the onus on the drawer of the bill-Forward contracts : the advantage to importers and exporters; the banker's position: how he sets off one operation against another-Forward sales of telegraphic transfers . . . .

\section{CHAPTER XV ON CREDITS}

TRAVELling letters of credit-The similarity and dissimilarity of confirmed and unconfirmed bankers' credits-Irrevocable credits-Clean credits-Documentary credits-London accepting credits and revolving credits-Credits without recourse: their effect-The benefits conferred upon the trading and mercantile community by the issue of commercial letters of credit . . . . . . 


\section{CHAPTER XVI}

\section{BILLS DRAWN UNDER VARIOUS CREDITS}

Bills drawn under a confirmed banker's credit : a specimen operation-Cases in which bills drawn on a London banker against nnconfirmed credits might be refused acceptance-Bills under clean credits-Documentary bills-Special points concerning the shipping documents attached to foreign bills : the bill of lading, insurance policies, invoice, certificates of origin, letters of hypothecation-The bills drawn under London acceptance credits: the question of exchange when proceeds are remitted to England-Currency bills.

\section{CHAPTER XVII}

METHODS BY WHICH EXPORTERS OBTAIN PAYMENT FOR

THEIR PRODUCE: PARTIAL DELIVERIES : MARGINAL DEPOSIT RECEIPTS AND TRUST RECEIPTS : BILLS ON THE FAR EASTERN COUNTRIES

THE financial standing and responsibility of parties to a bill : Opinion Lists-Documentary bills and London acceptances compared-Interest bills: the relative economy between bankers' acceptances in London and interest bills drawn on places abroad-The usance of bills on the East-Bankers' advances on bills-Marginal deposits: the interest allowed; the disadvantages of the system-Bills sent for collection-Partial delivery of goods: the danger inherent in the practice -The banker's security-The Trust Receipt System : its merits and demerits

\section{CHAPTER XVIII}

DOCUMENTARY BILLS ON AUSTRALIA, EGYPT, SOUTH

AFRICA, THE UNITED STATES OF AMERICA, AND OTHER COUNTRIES

Australasia : usance of bills : differences in exchange, how settled-Documentary bills: banker's right to use discretion regarding the surrender of documents - Homeward remittances : difference of opinion as to the method of remitting-Egypt : bills payable at par -Loss on exchange-Bills at current rate of exchange plus interest-Exchange as per endorsement: frequently disputed by drawees-Bills for collectionSouth Africa: differences in exchange-Usance of 
bills for which African banks quote-Bills for collection-The homeward remittances-Specimen billThe United States: American banks, possible competition with British institutions-Methods of drawing bills-Trust Receipt facilities-South American practice-The custom with Argentine and Brazil: tenor of bills; return remittances-Bills on the Argentine and Brazil marle payable in the principal centres of South America-European countries: bills drawnDocumentary demand drafts on the more important trading centres of Spain and Italy-Scandinavia : rate at which bills are collected-Difficulties in procuring return sterling remittances on London during the Great War-The method aclopted in Denmark to surmount the difficulty . • . • .

\section{CHAPTER XIX}

\section{ON FINANCE BILLS}

The various ways in which finance bills are drawn and paid-How they affect the Exchanges-The multiplication of drawings-Limits beyond which bills cannot be drawn-How the price for finance bills is calculated-Finance bills which are kite-flyers-An example of kite-flying in modern times-Accommodation paper - House paper-Pig on pork drawings-Bills drawn in connexion with crop requirements-Up-country advances . . . . . . . .

\section{CHAPTER XX}

\section{THE DISCOUNT MARKET. THE BILL-BROKER}

“Discounting " a bill : what it really means-The bills arising from inland trade which are discounted by the banker-Discount operations in which the banks do not deal direct with the sellers. Entry of the billbroker-The reasons for his presence on the London Money Market-The old private bankers and the present day bank managers-The bills with which the bill-broker has to deal: how they arise, and their classes-The bill-broker's operations-Foreign domicile bills and foreign agencies-D.A. and D.P. bills : their relative merits-The capital of the bill-broker -Thr point at which bill discounters enter into conpetition with the banks-The British Government's measures for financing the Great War by means of Treasury Bills 


\title{
FOREIGN EXCHANGE AND FOREIGN BILLS
}

\author{
CHAPTER I \\ INTRODUCTORY AND EXPLANATORY
}

THE pathway of international exchange is always a thorny one, and in the past writers have been apt to expound theories on the subject too abstruse to be intelligible to that illusive friend of the politicians-the man in the street. Technical dissertations on the exchanges may, and possibly do, interest bankers, money brokers and the like, but the general student who has to commence the subject from its very alphabet, so to speak, sometimes finds himself unable to grasp the intricacies of the problem set before him. Indeed, the method of controlling the foreign exchanges has been so little understood in these Islands, that when we see a person setting out to tackle the subject, it is difficult to know whether to pity or to envy him.

$\mathrm{He}$ is understood to be about to dabble in a branch of economics, the principles of which are interesting only to painstaking foreigners or much-abused university professors, the sort of thing, in fact, immortalized by George Eliot in her inimitable description of the Reverend Casaubon's heroic, dry-as-dust researches.

It need hardly be said that the dust surrounding the subject is more apparent than real, and if the reader will boldly cast aside this hypothetical covering, he will find the study of exchange in relation to monetary affairs to be both interesting and fascinating. 
Why the education authorities have hitherto refrained from including this branch of science in their curriculum it is hard to say: possibly it is due to that insular prejudice which regards anything off the beaten track as unworthy of attention, but the fact remains that while we have been content to relegate the study to the chosen few whose business it is to direct the banking operations of the country, large numbers of Continental students have been industriously acquiring a thorough theoretical knowledge of the foreign exchanges, with the not unnatural result that when practical problems in connexion with international finance come to be solved, the British bank clerk often finds himself ousted by the foreigner.

With the object of removing this reproach, the writer was requested by the Educational Adviser to the City of London College to deliver a series of lectures on the subject, and early in the course it became necessary to explain to university students the importance of the exchanges to those who contemplated the adoption of a commercial career.

"Why," it was asked, "is it necessary to acquire a knowledge of the principles underlying foreign exchange ?" Briefly stated, the reply was, that the trend of recent events amply demonstrated the necessity for something more than a passing acquaintance with the subject.

A person who has attained a reasonable degree of proficiency in the study of the foreign exchanges is able to understand clearly why a heavy Continental demand for gold adversely affects the price of money on the London market: he is in a position to comprehend why the breaking off of diplomatic relations between two nations causes wholesale dislocation on the stock markets of other distant countries: without soaring to prophetic heights he will be able to forecast the effect of a fall in the price of silver in London on the operations of those whose trade is with the Far East, and, in addition to grasping the significance of these panoramic changes, he will appreciate the real methods of liquidating international indebtedness. 
The reader must not conclude from the foregoing that it is an easy matter to master the intricacies of the subject, but it is desirable to add that the seeming difficulty of understanding the technicalities of foreign exchange, and likewise, foreign bills, is largely the result of a neglect to study the business in a workmanlike and systematic manner. Emphasis is laid on this point, because it has come to be considered in some circles that a thorough theoretical and practical knowledge of the exchanges is obtainable from a passing acquaintance with commerce, coupled with a cursory perusal of a few haphazard articles on this branch of monetary science: widespread confusion is the result.

Most persons with commercial training are perfectly entitled to form and maintain opinions concerning their own trade and the monetary operations connected therewith, but in default of continuous study, or of special experience, no man is competent to discourse upon the theory and practice of foreign exchange.

Throughout this book, then, the author imagines himself in the position of the person with no previous knowledge of the subject; and while every endeavour is made to demonstrate the various divisions step by step in a manner capable of being understood by the veriest tyro, it is hoped that the arrangement of the work will meet the needs of the more mature students.

It is the practice of many economic writers to commence their treatises with a definition of the particular part of the science with which they propose to deal, and in deference to that useful custom, we may conclude this introductory chapter with an explanation of the term "foreign exchanges."

\section{Meaning of Foreign Exchanges.}

As a mode of expression the words "foreign exchanges" form one of those meaningless phrases which have filtered down to us through the dust of antiquity. To the lay 
mind the words convey nothing, and unless you are a diligent reader of the money article, or have connexions with the banking world, foreign exchange might very well mean the exchange of a London pig for a Chinaman's opium bowl. It is all very well to say: "Oh! foreign exchange is merely the mechanism by which the money of one country is sold in another," when Tom, Dick or Harry is but dimly aware of the fact that money, as such, is ever bought and sold.

We may get to the root of the matter if we go back to the old system of barter; only, in this case we barter, not goods, but the value of goods, expressed in most cases by credit instruments-money substitutes. Consequently, the term signifies the practice prevailing among merchants in different centres or countries of regulating their mutual indebtedness without the transfer of metallic money from one country or the other. The trouble, risk, and expense of sending actual gold or silver from place to place are avoided as far as possible, by making use of a piece of paper, which may be in the form of a telegraphic order, or a bill of exchange.

The final operations are carried out by bankers and their foreign agents, but special note should be taken of the fact that it is the transactions of merchants upon which the wheels of international finance principally depend for their motive power.

In its simplest form, foreign exchange embraces all the hundred and one operations connected with the buying and selling of the substitutes for metallic money, and we shall arrive at a better understanding of the subject if we treat this money from the outset as a commodity, controlled by the same great laws of supply and demand which govern any other commodity.

The reader is advised to dismiss from his mind for the moment the fact that he is dealing in the monies of foreign countries, and instead, to regard bills of exchange as representing a definite commodity-a debt. In a word, 
it is debts which are bought and sold in foreign exchange, and the price of these follows exactly the same laws as any other article of commerce.

MacLeod, in his Theory of Banking, compares them with corn, and although he was not propounding the theory of the foreign exchanges, yet his analogy is so remarkably applicable to the case we have before us, that no apology is needed for quoting his words-

"If money is scarce," he says, " and wheat very abundant, the price of wheat must fall: if money is very abundant, the price of wheat will rise. The price of debts obeys the same rules. If money becomes very scarce, the price of debts must fall. . . If specie becomes abundant, the price of debts will rise. . . The price of debts, then, must follow the same great laws of nature that the price of wheat does." 1

That, in a nutshell, is the basis of the business of foreign exchange, which, as we shall see, principally consists in the purchase and sale of foreign debts in the guise of bills of exchange.

1 Theory and Practice of Banking, Book II, page 278. 


\section{CHAPTER II}

\section{THE BASIS OF FOREIGN EXCHANGE}

WHEN a banker discounts a bill for a client he buys what is, in effect, a debt owing, or to become due, to that client : the operation may correctly be described as a transfer of indebtedness, but it should be borne in mind that there is no ground for the popular statement that the act of the banker is to lend money to his customer.

\section{Buying and Selling of Debts.}

From our standpoint the banker really buys a definite, marketable commodity, and if the reader has literally interpreted the simple definition of monetary exchange adduced in the preceding chapter, he will realize that the commodities bought and sold in foreign exchange are nothing more nor less than international debts. Much confusion has been engendered by regarding these debts as being transferred from one to the other, not sold, and in the process people quite lose sight of the fact that each transfer or exchange is in itself an actual sale of a tangible article of commerce. It will tend to simplicity, therefore, if we regard foreign exchange as the buying and selling of debts between countries.

In its most elementary form this buying and selling of foreign indebtedness is usually represented as being carried out by one piece of paper transferred between four principals, thus: $\mathrm{A}$ and $\mathrm{B}$ are two persons residing in one locality different from the domicile of $\mathrm{C}$ and $\mathrm{D}$ : $\mathrm{A}$ in London, we will say, sells goods to C in Antwerp, while D in Antwerp sells produce to $B$ in London. To satisfy the four dealers engaged in these two transactions, obviously there must be a sale and purchase of two debts, or, to put it another way, one payment in Antwerp will be exchanged for one payment in London, and the manner in which the 
indebtedness is cancelled is almost ridiculous in its simplicity. London creditor A has a claim for Belgian francs and cents on $\mathrm{C}$, while $\mathrm{D}$ has a similar claim on $\mathrm{B}$ for the sterling equivalent. If it is assumed that each transaction is equal in value, then $A$ will sell C's debt to him to $B$ : $B$, being under the necessity of remitting funds to Antwerp, buys this claim on $\mathrm{C}$ in order to send it to $\mathrm{D}$, who will finally claim the cash from $\mathrm{C}$. In this manner four parties are satisfied, and, to state the case still more explicitly, Antwerp's claim on London, and London's claim on Antwerp are both settled through the instrumentality of a bill of exchange, which $\mathrm{A}$ is assumed to have drawn on $\mathrm{C}$; and the trouble, risk and expense of sending actual coin or bullion from place to place are avoided.

If the exchange could thus be satisfactorily disposed of, there would be little difficulty in comprehending the operations which take place; but, unfortunately, there are other points to consider. In our example we have assumed that $\mathrm{A}$ drew a bill on $\mathrm{C}$, and that after travelling round its allotted sphere this piece of paper found a resting place in D's portfolio until the date of payment. Then again, we have taken it for granted that the two debts were of equal value. In actual practice, however, such conditions rarely prevail. What really happens is, that A will draw a bill on $C, D$ will also draw on $B$, and as each party will require to be paid for his produce in the money of his own country, the exchange is effected through the medium of a banker. Finally, it is the banker who will adjust any balance which may arise owing to the different and varying proportion of the value of the currency of one country in the other.

If, then, as in this hypothetical case of two debts arising from the transactions between four traders, the total claims of any two countries are neither in a state of equality nor fall due for payment at the same time, it is apparent that this is the point at which the real exchange problem arises, since owing to the lack of coincidence in 
the total debts of the two nations there will remain a balance to be liquidated.

\section{Basis of International Indebtedness.}

The basis of this international indebtedness is foreign trade, and although the question naturally resolves itself into a consideration of the amount of exports and imports, it is not necessary in this book to enter into an extended discussion on international commerce. It will suffice if brief reference is made to the particular imports and exports which have a direct bearing on the subject under review.

The payments for imports and exports are undoubtedly among the most important with which the writer on exchange has to deal in examining international indebtedness, but there are other items of national expenditure which have an intimate connexion with the exchanges, and of these we shall take due cognizance when studying the exact points at which they affect the various rates.

Each trading nation has at times remittances to receive or to make in respect of its entire balance, and the principles involved in the discharge of this mutual indebtedness in no way differ from those seen in the settlement of debts between two individuals. The operation is similar, whether it be an isolated transaction between a London merchant and one on the other side of the world, or whether it be the transfer of a huge sum exacted from a conquered foe as a war indemnity. In each case the ultimate settlement is made in the actual currency of the creditor country. but the rate at which the exchange is effected is governed by the relative state of indebtedness between the nations concerned at the time the transfer is made. That exports pay for imports is undoubtedly true, and it is equally certain that the excess of the one over the other always creates a claim which influences the rate at which the final payment is calculated; but, having got thus far, we are face to face with the fact that there is no sure standard by which we can determine on which side the balance 
between any two countries lies, or, as Adam Smith shows, which of them exports to the greater value.

If it were possible for a country to find out by how much its exports exceeded its imports, it would be a comparatively easy matter to show the exact sum the importing country owed on balance, and when the money came to be sent out from the centre at which the debits exceeded the credits, the exchange could be calculated with some degree of accuracy, since the course of the exports and imports between two countries is considered to regulate the course of exchange between the two places. However, this course of exports and imports cannot be accurately gauged. For one thing, we cannot always set off goods against goods; sometimes imports or exports of commodities are paid for in kind; at other times they are exchanged for services, or vice versa. Italy, for example, in exchange for the gold brought into that country by the tourist may be said to give him the opportunity to risk his life in climbing the Alps, or France may permit him to view her invaluable art treasures at the Louvre in return for the cash he has imported into Paris. There is a direct import and export in each case, but no trace of either will be found in the trade returns of the various countries.

Then, again, in making remittances for shipments, merchants do not always send bills on the creditor country, but make use of other forms of remittances. For instance, they will pay a debt owing in France by means of bills on Switzerland ; or one due in Italy by a bill on Paris. All these operations tend to obscure the real rate of indebtedness between the countries concerned, and serve to show that the foreign exchanges in practice do not always conform to the principles which in theory they are expected to. Consequently, although the relative indebtedness, or balance of trade between two countries, does exercise a potent influence over the exchanges, it is entirely misleading to consider the excess of exports over imports, as shown in trade statistics, as the one and only factor to be 
taken into account. The components which constitute the final balance are much more complex, and to these we shall make further reference when examining the variations in the exchanges. For the present we must concern ourselves with the way in which the money of one country is exchanged into that of another country for the purpose of settling this final balance.

The liquidation of the indebtedness arising from foreign trade is, as far as merchants are concerned, carried out by means of bills of exchange, and, in carrying through the operations, each party avails himself of the services of a banker, who is the connecting link between the various interests. The banker in fact may be regarded as the wholesale dealer, carrying the stock of demand drafts, bills and cable payments which form the international currency on the principal financial centres of the world; and, ignoring for the moment the question of competition, supply and demand, etc., the prices at which he buys or sells his wares in the several currencies, are settled by certain well-defined rules, which we are now in a position to investigate. 


\section{CHAPTER III}

INTERNATIONAL CURRENCY, THE PAR OF EXCHANGE

AND THE MINT PAR OF EXCHANGE, WITH

SPECIAL REFERENCE TO AUSTRALIA

As we have invested the banker with the mantle of the wholesale dealer, let us examine the stock of international currency he is supposed to be carrying for the benefit of those wishing to deal in foreign exchange.

The first essential in any form of international currency is that it shall be convertible into the money of the country to which we wish to send it, at the will of the holder.

\section{Forms of Remittance.}

The instrument above all others endowed with this quality, is the bill of exchange, under which generic term are included demand drafts, cheques, and bills of exchange payable at so many days after sight or date. Occasions arise, however, when these ideal instruments are not obtainable, and it becomes necessary for the buyer to look round for other forms of remittance.

In what way will the demand be met?

The indebtedness can be cancelled equally well by purchasing another species of debt in the shape of coupons, bonds and the like. For example, if it is desired to make a remittance to Paris, in the absence of bills of exchange, coupons of the French Rentes can be dispatched to France ; or, should it be necessary to pay a creditor in New York, any of the standard securities which are due for payment may be sent. Warrants and coupons of the Canadian Pacific Railway, or of the New York Central Railway stocks, although not so much in evidence as the bill of exchange, are constantly being dispatched across the Atlantic in liquidation of indebtedness. 
In making special mention of this mode of remittance, it may be thought that the author is going dead against the theories advanced by the leading economists, who have hitherto regarded the purchase and sale of coupons and other international securities as arbitrage business, pure and simple. This is not the case. If we bear in mind that the instruments bought and sold in foreign exchange are foreign debts, it is plain that coupons come within that category, and although for various reasons it is considered to be more simple and preferable to purchase a bill of exchange, yet if bills are not available, the remitter can pay his debt quite as well by sending coupons payable in the creditor country. It is true that, as a rule, commercial men do not resort largely to this form of finance, but there is no doubt that bankers frequently make use of coupons for the purpose of transferring the actual balance of indebtedness. It is within the writer's knowledge, in fact, that large remittances of coupons of the internal Japanese loans are periodically sent from London to the East, and the foreign banks are quite as ready to purchase these coupons as they are to encash bills of exchange.

The fact remains, therefore, that coupons of the wellknown foreign stocks and shares are really a form of international currency, and there is no reason to mystify the student by referring to the buying and selling of these claims to a portion of the money of another country as unfathomable arbitrage operations. While it is no doubt the case that the bankers do most of the professional business of remitting funds from one country to another, yet it is within the power of any person who is under the obligation to send a sum of money abroad, himself to remit by first-class coupons of the foreign country if he so desire.

Having made this digression, we may return to a consideration of the rules which are said to enable us to calculate to a nicety the value in one country of the debts payable in others, 
In primeval days the question of barter must have caused much heart-burning among our ancestors. To settle, for instance, the number of pigs to be exchanged for a cow, was a problem well designed to bring out the qualities of a higgler until some definite standard of exchange could be decided upon. The inclination to higgle over every exchange is irresistible even at the present day, and nowhere is this trait more prominent than in settling the terms for the transfer of indebtedness. The main problem, however, in foreign exchange, is to a great extent simplified by the fixing of a basis upon which the metallic money of one country can be converted into that of another.

\section{Mint Par of Exchange.}

This basis of exchange between two systems of coinage is known as the Mint Par of Exchange, and may be best described as the rate at which the standard coin of one country is convertible into that of another country according to the terms of their respective Mint laws. This power of exchange can be established only between two countries whose legal currency unit is of the same metal: the relationship thus expressed must be between the standard coins of two gold-using countries, or between the silver coins of two silver-using countries. Between two countries having legal tender coins of a different metal, say of gold in one country and silver in the other, there is no par of exchange, and the reason that a comparison cannot be made is, that the exchange between gold and silver cannot be definitely fixed. The gold price of silver, as we shall see when we come to discuss the Eastern exchanges, varies from day to day, according to market conditions and other fluctuating elements.

In contradistinction to the Mint Par of Exchange, we may briefly refer to what is known as the Ideal or Hypothetical Par. The designation seems to have been handed down by writers on Political Economy, who were wont to 
use the term to describe the state of affairs which was supposed to exist when the opposing claims of two trading countries exactly balanced. Exchange, it was argued, will be at par when the total payments to be made to and from any two countries within a specified time, exactly balance each other. As we have seen, however, the many and varied factors which have to be taken into account in measuring a country's foreign trade, make it impossible to say with any approach to accuracy, when the exports and imports between two countries do exactly balance: consequently, it is not possible to state at what precise moment the opposing claims, being equivalent, can be set off the one against the other.

In point of fact, the Hypothetical Par is of no practical significance, and the only reason for mentioning it here is to show that people who are not well versed in the subject, tend to confuse it with Mint Par. Both indicate a state of equality, but the one is greatly different from the other.

The Mint Par of Exchange, although it is only a nominal par of exchange, does enable us to get at the exact rates for the interchange of currency by giving us a definite point from which to calculate the pricc of debts payable on demand or at some determinable future time.

The Mint Par being adduced from the metallic content of the respective coins as laid down by the coinage laws of the various countries, we are thus in a position to show how the relationship is established between any two of them whose standard is the same. Between any two such countries exchange would be at par, when, by paying a certain amount of the metallic money or its equivalent in one country, one could purchase the right to receive an equal amount of the same metal in the other country, but it does not follow that this ideal state will often, if ever, prevail.

\section{Australian Exchange.}

The exchange between England and Australia is the much quoted example of this state of equality, and the 
apology, if any be needed, for referring to it here, is that an erroneous impression is created by writers who give the Australian exchange as a standard example of the transfer of indebtedness at equal rates. In practice, however, the Mint Par is one thing, the buying and selling of these foreign debts another: the former is a fixed metallic basis on which to calculate the rates for the exchange, the latter is the actual operation, and it seems more correct to regard the Australian exchange as a simple illustration of the fact that the Mint Par is purely nominal.

Cambists get out of the difficulty by stating " there is no exchange on London," but we must carry the discussion a little further by examining the present position in regard to Australia.

The Australian Mints are branches of the British Royal Mint, and in both countries the bullion content of the "sovereign" is 123.27447 grains troy of gold, eleventwelfths fine, that is eleven-twelfths pure gold and onetwelfth alloy, and, strictly speaking, the par of exchange is $£ 1=£ 1$, or $£ 100=£ 100$. Theoretically, this par is fixed so long as the Mint laws of the two countries remain the same, but in practice we have to take cognizance of other factors, the principal of which is the ratio between exports and imports.

From details courteously supplied by Mr. G. H. Knibbs, the Commonwealth statistician, we find that prior to the year 1891 the balance of Australia's trade was, with few exceptions, on the side of imports-she had more to pay than to receive; but from 1891 down to 1912, the reverse was the case, and Australia had more to receive than to pay, for the balance of trade was consistently in her favour. The trade returns for 1912, however, indicated a marked decline in the ratio of exports to imports, and in 1913 Australia again imported more than she exported.

There are no special features about the trade statistics for the earlier years which particularly concern us: the excess of imports was due, partly to the introduction of 
the capital derived from the issue of Government loans, partly from capital sent out to Australia for financing private undertakings. The excess of exports for the twenty years, 1891-1912, arises from the interest and profits on the earlier investments, repayment of loans to foreign bond-holders, and also from payments for freight on cargo carried chiefly by vessels from Great Britain.

In explanation of the alteration in the balance of trade from an excess of exports-which had prevailed for twenty years past-to an excess of imports in 1913, instructive tables were prepared by the Government statistician. They are too long to reproduce here, but there is no need to study statistics in order to understand the matter. It is in Australia's borrowings that we have to look for the reason for a decline in the ratio of exports to imports. To make this clearer, let the reader imagine he is faced with the disagreeable necessity of raising a loan of $£ 10$ from a money-lender; when the latter pays the $£ 10$ it is in effect an import to the reader's income. Subsequent interest payments will show very little effect on his outgoings if paid regularly; it is when the loan is repaid to the money-lender that what we might term one's exports are affected. By a similar process of reasoning we arrive at the explanation for Australia's adverse balance. The various states have borrowed heavily on the London market during recent years, and each year the total proceeds of the loans, as paid, go to swell the import returns ; but, as Mr. Knibbs pointed out, as no immediate payment beyond the instalments of interest has to be made in return, the export figures are affected in a very minor degree: it is when the principal of the debt comes to be repaid that the export figures will show a marked increase.

The fact that Australia constantly exports large quantities of gold, has led many people into the error of supposing that such exports are entirely due to an adverse balance of trade. The gold shipments, however, are more attributable to the gold production of the country than to any 
liquidation of indebtedness, and although Australia's being a gold-producing country is of considerable interest, we cannot dismiss the question of her exchange with Great Britain so simply: it is governed by many factors, of which gold production is only one and by no means the most important. Rates fluctuate considerably, according to circumstances ruling at the time, and exchange is not always at par. The payments which Australia has to make on account of the interest on her heavy debt to Great Britain may not be very visible in her export statistics, but they frequently cause, what we may call the "balance of exchange" to become adverse.

Then, our trade with Australia is not so constant as with other countries with which we have intimate trade relations, and as a result we find the Australian exchange to be governed by seasonal influences, of which the principal are the wool and grain exports. The wool season commences in October and lasts until February ; grain exports also continue for about the same period, and arising from this activity in the export trade, there will be a heavy influx of money into London, represented by bills of exchange. In this case the Australian banks here have a plethora of funds, and it may be possible for a person who wishes to remit money, say, to Sydney or to Melbourne, to purchase a demand or sight draft at par ; if he wishes to telegraph the money, a small premium may even be allowed him, that is to say, the banker will cable $£ 100$ to be paid in Australia in exchange for an amount slightly under $£ 100$ paid in London.

It may be rather different when there is a scarcity of funds in either Australia or London, and the buyer or seller will be charged a rate corresponding to the existing circumstances.

As far as bills are concerned, the rate of interest for the time the purchasers are out of their money will also have to be taken into account.

Apart from these influences, the geographical situation 
is a factor which has to be borne in mind : rates for remittances to New Zealand or to South Australia may differ from those charged and paid for similar transfers to other parts of the Australian Continent.

Finally, we must bear in mind that the operations in bills of exchange are mainly in the hands of the banks, and the question whether a draft can be procured at par, depends to a large extent not only on their local financial position at the time, but whether profitable operations are immediately available for the employment of the liquid funds they receive in exchange for the drafts issued.

The statement that a sum of money can be cabled from London to Australia, or vice versa, at par, should also not be accepted without qualification.

In buying and selling bills of exchange, other people are obliged to work through the intermediary of the banks, but in regard to telegraphic transfers the bankers themselves are in an anomalous position. They base their operations on rates fixed in consultation with one another, and are often under-sold by parties outside the pale of their charmed circle. A merchant, for example, who desires to remit $£ 20,000$ by cable to Australia, may find it convenient to get into touch with others having funds at their disposal there, and as the result of bargaining will get the transfer made at a lower rate than can be given by the bank, which has always to minister to the requirements of its customers, whether it can find a "set-off" or not.

From a consideration of these facts it must be fairly obvious that equality of exchange between Australia and London is the exception rather than the rule; the margin of profit always exacted by the person supplying the transfer, convincingly disproves the popular statement that there is often no difference between buying and selling rates in Australasian exchange.

Now let us examine this fixed basis of exchange as established between Great Britain and other countries, 
which, while they conform to the gold standard, yet have a currency system different from our own.

\section{England and France.}

We may take the comparison between England and France as a commencement, and our equation will be based on the coinage laws of the two countries.

Reference to the English Coinage Act of 1870 will show that a sovereign is ordained to weigh 123.27447 grains troy, or 7.98805 grammes of gold, eleven-twelfths fine. The French Mint Laws enact that one kilogramme $(1,000$ grammes) of gold, nine-tenths fine (or, 900 parts fine gold, 100 parts alloy), shall be coined into 3,100 francs. There is really no golden franc in France; the legal tender unit is the silver franc, which derives its gold basis from the Mint Laws, while 3,100 francs is a simple way of expressing the equivalent of 155 twenty-franc gold pieces (or Napoleons).

\section{Chain Rule.}

Given these particulars we can get at the equation between the respective currencies by a simple application of Chain Rule, a method of reasoning with which all students of exchange should make themselves acquainted. It is rather beyond the scope of this work to explain the principles of Chain Rule, but it may be well to set out clearly the process to be employed in our first example.

Chain Rule consists of a series of equations arranged in two columns, each equation expressing the sequence or relationship between the two quantities. Starting from the first equation, which is a statement of the question, we express a definite relation between that and the second, the second and the third, the third and the fourth, and so on. There need be no difficulty in mastering the Rule if the student will remember to commence each equation in terms of the preceding quantity, and to conclude the Chain in terms of the answer required; thus, if you begin the 
equation with francs on the left-hand side, the final quantity on the right-hand side must also be francs. The last point to bear in mind is, that quantities on the righthand side form the numerator, and those on the left-hand side, the denominator; the product of the numerator divided by the product of the denominator will then give the required answer.

We may now apply the Rule to show the Mint Par of Exchange between Great Britain and France, and this is how the sum appears-

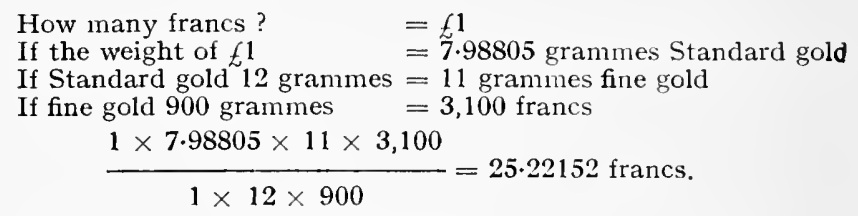

Therefore $£ 1=$ Francs $25 \cdot 22152$, which is the rate at which the currency of the one country is convertible into that of the other, and, theoretically, is taken to indicate that in accordance with the existing Mint Laws of Great Britain and France, Francs 25.2215 contain pure gold of the same weight and fineness as that contained in one sovereign. This, of course, is only assumption, as no account is taken of loss of weight due to wear or other causes, but so long as the currency of each country is based on gold, and no alteration takes place in the Coinage Laws, it must be taken as the fixed Mint Par Exchange.

\section{England and Germany.}

The German standard of fineness for gold is the same as the French, namely, nine-tenths fine quality, or 900 parts fine gold to 100 parts alloy or copper. Their Coinage Act of 1873 ordains that the German Mint pound of gold shall be coined into $69 \frac{3}{4}$ twenty-mark pieces, and, as we know the English basis of reckoning, we can set the problem out in the following way: How many marks equal one sovereign, when one German Mint pound of pure gold (i.e., 500 grammes) is coined into $69 \frac{3}{4}$ twenty-mark pieces, nine-tenths fine? 
Marks ?

$=\notin 1$

If the weight of $£ 1 \quad=7.98805$ grammes Standard gold

If Standard gold 12 grammes $=11$ grammes fine gold

If fine gold 500 grammes $=1,395$ marks $\left(69 \frac{3}{4} \times 20\right)$

$$
\frac{1 \times 7.98805 \times 11 \times 1,395}{1 \times 12 \times 500}=\text { Marks } 20.429
$$

Hence the Mint Par of Exchange between Great Britain and Germany is $£ 1=$ Marks 20.429 , or, to put it another way, 20.429 is the number of Marks containing exactly the same amount of gold as is contained in one British sovereign.

\section{England and the United States.}

To complete the trio, the method of finding the Mint Par with the United States of America is given.

Here again the arithmetic is a question of the Coinage Laws of the two countries. The currency unit in the United States is the Dollar. The golden eagle $=\$ 10$, is enacted to weigh 258 grains of gold, nine-tenths fine $=232.2$ $\left(258 \times \frac{9}{10}\right)$ as against our sovereign, containing 123.274 grains of gold, eleven-twelfths fine, which gives-

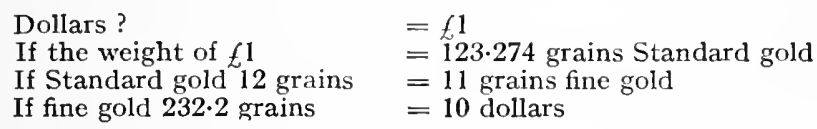

$$
\frac{1 \times 123.274 \times 11 \times 10}{1 \times 12 \times 232.2}=\$ 4.8665
$$

Consequently, the Mint Par in this case is $£ 1=\$ 4 \cdot 8665$, or, as many people prefer to call it, $49_{\frac{5}{16}} \mathrm{~d}$. $=\$ 1$.

The Mint Pars of Exchange between Great Britain and all other countries on the gold standard can be similarly calculated, and the following list will be useful to those who wish to see at a glance which nations have a Mint Par with this country.

The table is based on the details given in Tate's Cambist, which may be taken as the standard work on what is called "the arithmetic of the foreign exchanges." 
The Mint Pars of Exchange between Great Britain and Those Countries whose Currency is Based on Gold.
Great Britain (Standard weight of gold sovereign is 123.2744 and $\{$ grains, or 7.98805 grammes, eleven-twelfths Australia . ( fine
Par of exchange between England and Australia $\hbar^{1}=t_{1}$, subject to the limitations laid down in this chapter.
France $\quad 155$ twenty-franc gold pieces weigh 1 kilogramme : out of 1 kilogramme, 900 fine, 3,100 francs are to be coined.
Mint Par - London-Paris : $£_{1}^{1}=$ Francs $25 \cdot 22152$.
The Mark is the standard unit: Mint pound is Germany . . equal to 500 grammes, and is coined into 1,395 marks, 900 fine.
Mint Par-London-Berlin : $\ell_{1}=$ Marks 20.429, say, Marks 20.43.
United States of America
The standard unit is the Gold Dollar, weighing 25.8 grains; so that the Eagle, equal to 10 dollars, weighs 258 grains of gold, 900 fine.
Mint Par - London-New York: $£ 1=\$ 4.8665$.
The gold coin is the 10 Florin piece, which The weighs 6.720 grammes. Mint pound is equal to 500 grammes, 900 fine ; the relation between Netherlands $\left\{\begin{array}{l}\text { the British and Dutch weights of the precious } \\ \text { the }\end{array}\right.$ metals is, therefore, similar to the relation between British and French; $3 \frac{1}{4}$ per cent. is charged by the Dutch Mint for coinage.

Mlint Par - London-Amsterdam : $£_{1}=$ Fl. 12.071.

\begin{tabular}{|c|c|}
\hline Austria & - $\left\{\begin{array}{l}\text { Unit of value is the Krone }=100 \text { heller. One } \\
\text { kilogramme of gold is coined into Kronen } 3,280, \\
900 \text { fine. }\end{array}\right.$ \\
\hline Belgium & $\begin{array}{l}\text { Mint Par - London-Vienna : } £^{1}=\mathrm{Kr} .24 \cdot 02 \text {. } \\
\text { - }\left\{\begin{array}{l}\text { Monetary system is similar to France. There- } \\
\text { fore, the Mint Par (London-Brussels) is to all } \\
\text { intents and purposes the same as London-Paris. }\end{array}\right.\end{array}$ \\
\hline $\begin{array}{l}\text { Denmark } \\
\text { Sweden } \\
\text { Norway }\end{array}$ &.$:\left\{\begin{array}{l}\text { These three countries, forming the Scandinavian } \\
\text { Union, have a uniform gold coinage Unit of } \\
\text { value is the Krone (crown), and } 1 \text { kilogramme } \\
\text { of gold, } 900 \text { fine, is coined into } 2,480 \text { crowns. }\end{array}\right.$ \\
\hline
\end{tabular}

These are the principal Mint Pars with Great Britain, but in practice it will be found that France, Germany, the United States of America, and Austria, receive most attention on account of their active gold markets. 


\section{CHAPTER IV}

THE MINT PAR AND GOLD OR SPECIE POINTS IN THEORY AND IN PRACTICE

As the result of the problems elucidated in the previous chapter, the mundane business in foreign exchange has perhaps been divested of half its terrors, and the painstaking enquirer begins to perceive the reasons for establishing a definite comparison between the currencies of those countries which adhere to the same metallic standard.

In point of fact, the amount of metal of the standard unit of one country contained in that of another country is of academic interest only, since the greater number of the operations in foreign exchange are carried out by means of bills of exchange, and the actual transfer of coin or bullion scarcely concerns the average man. The fixing of the Mint Par, however, is necessary as a basis upon which the latter can calculate the worth of the bill of exchange he has to buy or sell, as the case may be. If a debt equivalent to $£ 100$ has to be paid by a merchant in England to a creditor in France, the parties to the transaction must have an agreed rate at which the exchange is effected, and the Mint Par will be the starting-point for their calculation.

Let us trace the operation step by step.

Suppose Messrs. Peter Robinson \& Co., London, owe Pièrre Rocher, of Lyons, $£ 100$, for silk purchased. The silk merchant does not want payment in English pounds, shillings or pence, as our currency will be practically useless to him in Lyons; he requires a remittance to be in francs and centimes, the recognized medium of exchange in his native town. How, then, will the debt be settled?

Peter Robinson, in consultation with his banker or other financial luminary, will find out that according to the legal enactments laid down by the two countries, $£ 1$ in England 
is worth francs $25 \cdot 2215$ in France; he can, therefore, buy a bill of exchange for francs $2522.15(25.2215 \times 100)$, and send it to his creditor at Lyons in settlement of the debt.

These facts, baldly stated, indicate what happens, in theory ; in practice, the business does not work out quite so simply. For one thing, in saying that the sum was transferred from London to Lyons, we have assumed that the amount of indebtedness between two countries is at "par" - that is, equal. In other words, the one nation has to receive the identical amount which it has to pay to the other, and, consequently, the total indebtedness is cancelled by that simple expedient, a set-off ; in the same manner, in fact, as two opposing claims are sometimes satisfied in an inland town. Needless to say, this ideal parity, or point of equilibrium, in foreign exchange rarely exists. Rates will be governed by a variety of circumstances, and in general, the price at which debts can be bought and sold will be largely influenced by the supply of, and demand for, bills of exchange, through the intermediary of which the transfers are usually effected.

There is another point to bear in mind. It must be evident that the British debtor is under the obligation to send a bill of exchange for a sufficient sum to outturn the exact amount of the debt which he owes to his creditor, neither more nor less ; and it matters not whether his bill is payable at sight or at some fixed or determinable future time, the piece of paper must give the foreign creditor a claim to that amount of the currency of his own country which will quite clear off the debt on the day it is received.

As illustrating the case where the opposing claims of two countries are not in this state of equality, let us take an operation between New York and London. We will suppose in this instance that an American dealer owes a merchant in the City of London $£ 3,000$. At the particular time the money becomes due, exports from Great Britain to the United States largely exceed Great Britain's 
American imports, consequently on this side of the Atlantic we shall have more money to receive than to pay; in a word, New York is under the obligation to remit to London, and there will be more buyers of bills of exchange on the New York market than there are sellers. Now, if the reader has remembered the closing words of the first chapter, he will know that he is dealing in "debts." The bills of exchange sold on the New York market, drawn on England, are debts owing by some one in England; the selling of them in the United States by the holders is merely a convenient way of collecting the amount from the creditor. Very well, then, if, owing to the cause indicated, these debts are scarce, it is obvious that they must be subject to the same rules as those governing commodities: they will rise in price. The exchange between the two countries is, therefore, no longer at par, and the debtor who is under the painful necessity of putting his creditor in funds, will, failing his being able to put off the evil day until a more propitious season, have to pay more for the claim to a few of the British sovereigns, which alone can satisfy the person in London.

When this state of affairs obtains, the American is supposed to have arrived at the point at which he will have to send to the creditor a certain quantity of gold to cancel the indebtedness. But, to avoid the many troubles and anxieties attendant upon gold shipments, there is still another way open to him. We, imagining for the moment that we are all bankers, will manufacture a bill for him. This calls for explanation.

\section{Bank Paper.}

If the bills for sale on the New York market have been purchased by the fortunate few who were early in the ficld, the reader, not unnaturally, wonders whence emanates the supply for the late comers. Here again, the conditions are closely akin to those ruling in the produce markets. In the ordinary commercial or manufacturing centres 
increased demand always results in increased supplies, prices and other things being equal. So it is with the bill markets; when the bills on offer have been exhausted, there will generally be found a number of bankers and exchange dealers ready to " manufacture a bill " to order -at a price be it noted.

In order to make such operations possible, the bankers arrange to have funds available in the hands of foreign houses or correspondents, and when it suits their purpose, they will be prepared to draw on the correspondent, that is, they will draw a bill of exchange, either on demand or at so many days date or sight, according to the exigencies of the case. As the banker has deposited the necessary funds at some previous date with his correspondent, these bills may be said to represent the whole, or part of that correspondent's debt to the banker drawing the bill, and for the purpose of remittance these bills are as good as any other bills, the supply of which, as we have seen, was insufficient to meet the demand. They are better, in fact, than the ordinary trade bills. In the latter case, what the market calls the "personal equation" enters into the matter, that is, we take into consideration the greater or less confidence which may be placed in the signature of the drawer. The lower price paid for the commercial bill involves what is in reality an allowance or compensation for this extra risk, however small, the buyer takes.

The merits and demerits of the two classes of paper will be seen when we come to discuss the " course of exchange," but having taken note of the difference, we may proceed to examine the manner in which Penrod, the New York debtor, finally liquidates his debt with Jones, the London creditor.

As we saw, the Mint Par, New York-London, is $\$ 4 \cdot 866$ $=£ 1$, but as the demand for remittances to London has exceeded the supply of bills, the exchange between the United States of America and Great Britain will be above this parity: it is favourable to this country, unfavourable 
to America, and instcad of getting his bill for $£ 3,000$, which is the currency he must send to Jones, at the Nint Parity, Penrod will be obliged to pay the higher rate which the banker exacts for manufacturing him a bill of exchange. The price he will pay for this banker's bill will be commensurate with the demand for "Bank Paper," the term used to describe this class of remittance, and the greater the demand the higher will be the cost. If the exchange be fixed by the banker at $\$ 4.88$ to $£ 1$, the draft will cost $\$ 14,640.00$, which will be $\$ 42.00$ more than the price of a bill at the Mint parity. In short, Penrod has paid $\$ 14,640.00$ for the right to have paid to him, or to his creditor Jones, the sum of $£ 3,000$ in London, and it is apparent that we do not vary the price by adding to the amount of the bill for $£ 3,000$, but secure the difference by varying the rate at which the American currency is converted into sterling.

\section{Limit of Price of Bills.}

It is at this stage the rules governing the purchase and sale of commodities diverge from those which govern the dealings in debts. In ordinary trade, the production of goods will continue as long as there is a demand for them, and the price will tend to rise in proportion to the excess of the demand over the supply: prices will rise until a point is reached when, through excessive production or other cause, the demand is satisfied; then the reverse action will take place.

The operations in bills of exchange are confined within much narrower limits, and to appreciate the extent of these limits it will be well to refer to the reasons for sending bills of exchange in settlement of international indebtedness.

In inland transactions, we use, for convenience and in order to economize gold, cheques, which are bills of exchange payable on demand; similar considerations influence the using of bills of exchange in foreign commerce, only the 
saving of time, trouble, risk and expense is very much greater. If the debtor can procure a bill of exchange, neither he nor the creditor will wish to be bothered about getting the coin converted from the currency of one country into that of the other, more especially so, when by remitting a bill, both are relieved from the anxiety which the shipping of gold coin or bullion always entails.

The point at which the augmentation in the price of commodities will stop is, to some extent, problematical, but it is not so with the price of bills of exchange. The debtor will buy them only so long as their cost does not exceed the cost of shipping gold, and the point at which it is just as cheap to send the metal to his creditor, will mark the limit of the premium on the bills of exchange. If the sellers of bills ask a price above this point, the New York merchant will send gold rather than pay the enhanced premium.

As far as New York is concerned, the charges for shipping gold to London, in normal times, may be reckoned as $\cdot 024$ cents, and if we add these charges to the Mint Par we shall get the outgoing gold point from New York.

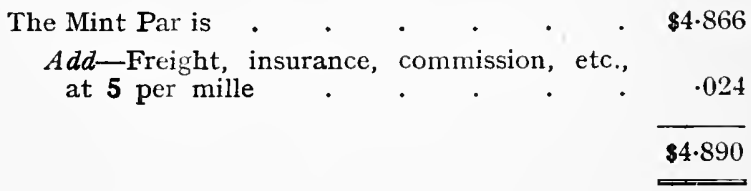

The $\$ 4: 890$ we may assume to be the limit beyond which the American debtor will not go in buying bills of exchange on London.

In the case of the supply of bills on the New York market exceeding the demand, the opposite state of affairs will prevail: the price for the paper falls away until the limit is reached at which the holders of the bills, the American creditors in this case, will rather withdraw gold from London than sell bills at a lower discount. To find 
this point, we deduct the shipping charges from the Mint Par, 8 per mille.

\begin{tabular}{ccccc} 
Mint Par &. &. &. &. \\
Less Shipping Charges &. & $\cdot$ & $\cdot$ & .0669 \\
& & & $\$ 4.827$ \\
\hline
\end{tabular}

\section{Gold Points.}

From these calculations we gather that at $\$ 4 \cdot 89$ to $£ 1$, gold will be sent from New York to London in preference to sending bills of exchange, and that at $\$ 4 \cdot 827$ to $£ 1$, it will be more profitable for the New York creditor to draw gold from London than to sell bills in sterling.

These rates are what are known as Gold Points, or, as some people prefer to call them, Specie Points, and, in order to impress them upon the reader's mind, we may repeat, that the outgoing specie point of a country is the rate at which gold leaves, and the incoming point is the rate at which the gold enters a country.

As the result of our investigation, three facts are now prominently before us. First, we see that the principal, if not the only reason, for our using bills of exchange in international commerce is to save the expense, risk and trouble incidental to the dispatching of gold. Secondly, when the merchant or other debtor has arrived at the parting of the ways, and is forced to choose between paying a price for the bills of exchange higher than the cost of sending gold to his creditors, he is said to adopt the latter alternative. Thirdly, when the seller of bills of exchange finds the price offered for his paper to be lower than the expense of importing gold, he will elect to take the gold from the debtor country. We thus get two gold or specie points between two countries, the import specie point being found by deducting the shipping charges from the Mint Par, and the export specie point by adding the shipping expenses to the Mint Par. 
In practice the solitary debtor, or even body of debtors, is little concerned with these specie points, and although for the sake of simplicity we have assumed gold shipments to be carried out by debtors, yet in reality it is the bankers who ultimately carry through the transactions. The banker serves as the connecting link between buyers and sellers of exchange, and in the same way acts as the necessary intermediary for buying and selling gold: but this does not affect the theory one whit, since the banker merely takes upon himself as it were, the load of debts from one particular centre, and forthwith proceeds to liquidate them in the manner most profitable to himself. We will, therefore, transfer our attention to the banker and endeavour to trace the steps by which he arrives at the disagreeable necessity of shipping gold.

We saw that in selling paper to his client, the banker draws the drafts on funds which he had previously deposited with his foreign correspondent: but it may happen, in view of the profitable exchange, that the banker has sold bills which in the aggregate far exceed the sum at his disposal with the correspondent, or, as not infrequently occurs, he has made arrangements with the latter to accept or pay his drawings up to a certain specified limit. In either case the banker will be obliged to cover his drawings, that is, he must see that the correspondent is put in funds to meet the bills in good time. In many cases this will be done by the banker's sending bills which he, in his turn, has purchased from various sellers on his own market. In New York, he may have bought bills drawn on London during the interval between the departure of one mail and another, and perhaps, on the very mail day the banker expects to remit the bills to London for encashment, a client is forced to buy a draft from him. The banker will sell this draft, usually at a fair profit, and it is not unusual for the customer to send it to London in settlement of some debt or other by the same steamer which carries the batch of bills previously purchased by the banker. The British 
correspondent will in due course collect the bills sent lim for encashment, and with the proceeds he is in a position to meet the bill, sold at the last moment by the New York banker, which bill we may suppose is for an amount equal to the total of the other drafts remitted to him by the American. The profit on such an operation is apparent. In any case, the banker endeavours to cover his sales by purchasing other bills on the cheapest market, but he cannot always work the exchange in such a convenient manner as that we have just described. If the banker is unable to buy bills direct on London to cover his sales of drafts, he will resort to purchases of bills on a third, or even fourth country. These bills he will dispatch to his accredited correspondent in each centre, with instructions to remit the proceeds to the credit of this account with the banker or other correspondent in London upon whom he has drawn the bills which comprised his sales in New York. In course of time he finds he has burnt all his bridges, exchange will go against him on the other markets, and in default of cover at reasonable rates, as a last resource he will be obliged to ship gold and sell it on the London market at the price fixed by law.

It is also the banker who is ultimately responsible for the gold shipment which is drawn from a debtor country when the import specie point is reached in the creditor country. Theoretically, the ordinary seller will not dispose of his bill, but will prefer to send it direct to the creditor for payment, and so draw gold from the country the exchange is against. In practice, however, the selling will still go on as in the converse case, and it is the bankers who will arrange the gold shipments; they themselves will be the buyers of the bills from the holders at or about specie point, and will subsequently send the bills over to the country with the unfavourable exchange.

'The object of the bankers' remitting these bills to the debtor country is obviously to recoup themselves for their outlay on the purchase of gold, which must still be sent 
to cancel the indebtedness between two centres, but it should be noted that the bankers' action in taking these surplus bills off the market, while not stopping the gold shipments, does serve to prevent the exchange's falling far below gold point.

Finally, in each case, that of the gold coming into the country, and that in which it goes out, the ultimate effect is the same as is seen in the importation and exportation of any other commodity: the relative balance of indebtedness between the two countries will soon be turned, and when once the equilibrium is restored, assuming trade conditions to be normal, the ordinary buying and selling of paper will recommence.

We see, therefore, that in ordinary circumstances, the exchange student is not directly concerned with the actual shipping of gold, which is a business in the hands of specialists, but it has been necessary to enlarge on the subject in order that a correct understanding be reached in regard to the gold points, the true significance of which we are now in a position to appreciate.

In discussing the Mint Par, we ascertained that there were a number of countries the interchange of whose currency could be calculated on a fixed basis laid down by their own laws, and in view of the foregoing explanation, it is now quite easy to realize that the gold points are those rates of exchange which will be produced by buying gold in one country, and selling it in one or other of those countries with which we have a Mint Par. The rate at which these countries will exchange the gold into their. own legal tender is definitely stated, and we have only to add or deduct the cost of shipping the gold in order to see which exchange is for us and which against us.

In order to make this book as practical as possible, we will now glance at the table of Gold Points, which is published weekly in the Economist, and see for ourselves how they are actually worked out. The following table is taken from the issue of 30th January, 1915. 
Gold Points.

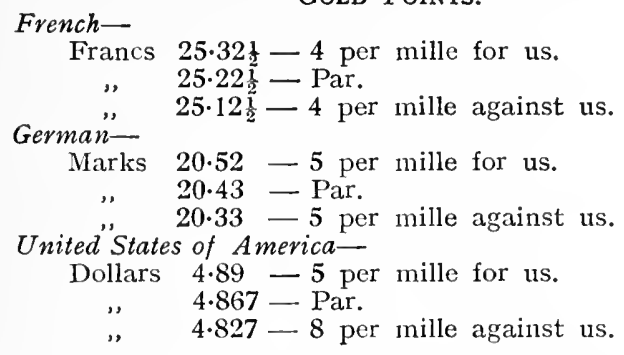

For the moment, we may assume that the countries in question allow their State Banks, or those acting in that capacity, to pay out gold for export as and when desired, and as we know that the gold points are the rates of exchange produced by buying gold in one country and selling it in another, we can soon see how the banker works out his rates.

Let us take the case of France. The first figures in the table, Fcs. $25 \cdot 32 \frac{1}{2}-4$ per mille for us, mean that exchange is in our favour, and gold should commence to leave the French shores for London.

The fixed Mint Par between London and Paris is Fcs. 25.225 Add 4 per mille for freight, packing, etc.

Fcs. 25.325

i.e., Fcs. $25 \cdot 32 \frac{1}{2}$, which is the rate at which it will pay the banker to take gold from the Bank of France, ship it to London, and receive from the Bank of England in exchange British currency based on the Mint Par Fcs. 25.225 =: $£$.

With Germany we will take as an example the last figures in the table, namely, Mks. 20.33-5 mille against us, which indicate that the exchange is unfavourable to England, that is, we have more to pay than to receive from Germany.

The fixed Mint Par with Berlin is . Marks 20.43 $=£ 1$. Deduct 5 per mille for freight, packing, etc.

Marks $20 \cdot 33$ 
This will be the outgoing specie point from London, and it will consequently pay the banker to turn Bank of England notes into gold at the Bank of England, ship the gold to Germany, and sell it to the German Reichsbank.

As far as the United States of America are concerned, we see that it costs $\mathbf{5}$ per mille to send gold from New York to London, but that when the exchange is against us, our expenses for shipment are 8 per mille. The extra 3 per mille are deducted from the Mint Par to make up for the interest the British exporter of gold loses on the shipment, which is easily accounted for. In New York, when a consignment of gold is sent out, the American shipper can at once recoup himself by selling his bill on London, but with shipments from London to New York, the banker is unable to do this, since bills in sufficient quantity drawn on America cannot be obtained on the London market; consequently, we have to wait for the return remittance from America before we are in funds again, hence the extra charge of 3 per mille for loss of interest.

Our real difficulty in regard to these specie points is, that they do not in practice conform to the limits which, in theory, are assigned to them: between each centre we often find the rates varying, according to the distance from London. Unlike the Mint Par, which is invariable as long as the coinage laws of Great Britain and other gold standard countries remain the same, the specie points are affected by variations in the cost of freight, insurance, packing, and commission, and in many cases interest has to be taken into account. Then, as has been evident during the Great War, shipping risk and other circumstances affect the gold movements.

Apart from these factors, the manner in which the points will diverge from the fixed limits in practice will often depend upon the peculiar advantages within reach of each shipper. Onc consignor, for instance, may have special facilities for packing, another may be offered concessions by the Mint authorities in the receiving country, while a 
third shipper, being able to send the gold forward in larger quantities than the rest, gets a reduction in the freight, and all or any of these concessions materially reduce the ultimate rate. When shipping coins, too, there must also be considered the allowance which will have to be made for the gold pieces worn and under full weight.

The reader will therefore perceive that it is difficult to fix these specie points with absolute precision, and although they are theoretically correct, recent events have demonstrated all too clearly that we must not take them as definitely established.

We do not, however, need war conditions to prove that the limit points are only approximately correct : reference to the money article of the daily newspapers, or to the weekly figures given in such papers as the Econumist, will indicate that while we in Great Britain generally allow gold to leave our shores without let or hindrance, other nations act in a much more guarded way. We may therefore conclude this chapter with a brief summary of the actual conditions, as far as they are ascertainable, it being understood that the position of the foreign exchanges during the war is reserved for discussion at a later stage.

\section{England a Free Gold Market.}

In the first place we can still confidently assert that in England there is an absolutely free gold market. The Bank of England's efforts to retain or obtain gold are practically confined to variations in the rate of discount, and, very occasionally, to outbidding other dealers for the bar gold which arrives week by week from South Africa and other parts. It is not over-stating the case to say that our arrangements very often appear to be in favour of the foreigner, since when the exchange rates are against us gold rarely fails to leave the country, but when they are in our favour great reluctance is shown by other centres in sending the metal to us. 
The export gold point New York-London, is $\$ 4.89$ $=£ 1$, and as there are practically no restrictions on the free export of gold, the metal will, as a general rule, tend to leave the United States shortly after that limit is reached. There was a marked example of this in the period, April to June, 1914. The official trade statistics of the United States showed that during the month of April imports exceeded exports by some $\$ 10,000,000(£ 2,000,000$, taking $\$ 5=£ 1$ ), and as other forms of remittance were insufficient to satisfy America's foreign creditors, New York was obliged to export gold in settlement of her indebtedness.

On turning to France, we find the outgoing gold point, Paris-London to be Fcs. $25 \cdot 32 \frac{1}{2}=£ 1$, but when exchange reaches that point, or lower, gold leaves France only when it suits the Bank of France to let it go. Gold cannot be procured from the State Bank by simply presenting notes; silver is also legal tender in France, and that metal can be paid out if it be deemed expedient. Gold, of course, can be picked up in small lots from outside sources, such as from the railways, the tourist agencies, etc., but when it is a case of fulfilling large contracts, the exporters are dependent upon the whims of the Bank of France: if the Bank is satisfied with its reserves, the gold may be forthcoming: if demands are at all heavy, and the exporters press for gold, a premium is charged, which naturally causes a divergence in the specie point : when for political or other reasons, the authorities feel it incumbent upon them to maintain their supply, however, the gold will not be issued at all. It is no unusual thing for the exchange to be in favour of London for days without gold reaching this country.

For the week ending 3rd January, 1914, French exchange stood at Fcs. $25 \cdot 30=3$ per mille for us, 10th January Fcs. $25 \cdot 26 \frac{1}{2}=1 \frac{3}{5}$ per mille for us, and on 17th January Fcs. $25 \cdot 25 \frac{1}{2}=1 \frac{1}{5}$ per mille for us. In such circumstances one would not have expected gold to leave this country, since Fcs. $25 \cdot 12 \frac{1}{2}$ marks the point at which gold is said to go 
from London to Paris, but on 12th January $£ 100,000$ was actually taken from the Bank of England and shipped to France.

The German authorities adopt even a stronger policy in regard to the Reichsbank's gold reserves. Prior to the war, their attitude was very rigid; what it will be in the future remains to be seen. It has always been argued that Germany's arrangements closely conformed to the British in so far as gold is attracted by raising the rate of discount, but when it came to parting with the metal, many obstacles were placed in the way of exporters, and it is not too much to say that gold could rarely be secured from Berlin when exchange was against that city.

Reference to the Economist weekly tables will show that each week, from January to August, 1914, rates were favourable to London. Take a few examples-

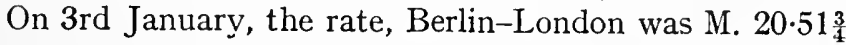
$=4 \frac{7}{8}$ per mille for us.

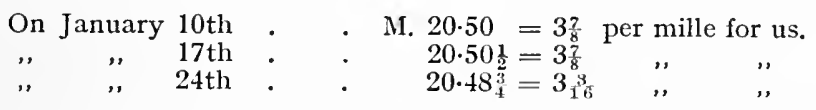

From February to April the rate varied between $\frac{1}{4}$ to $1 \frac{2}{5}$ per mille in favour of London, and from May onwards it went steadily against Berlin, but needless to say, there was no question of gold coming to London, and although the outgoing specie point, London-Berlin, was never once reached in the period named, yet a good deal of gold found its way to Berlin from our shores. Even when rates were actually against Berlin gold left England. On 28th and 29 th July, 1914, the quotation was $20 \mathrm{~m}$. 53-55pf. and $20 \mathrm{~m}$. $55-70$ pf. respectively: in sovereigns alone $£ 847,000$ were taken from the Bank of England "for the Continent" on the dates named, and as gold coin was also withdrawr for other European centres on the same days and the destination stated, there is no doubt the portion described as "for the Continent" went to Germany.

We are forced to admit that the Reichsbank gives 4-(1525) 
liberal facilities to gold importers. For instance, credit is often given in Berlin for gold that has only reached Hamburg, which means a gain in interest to the importer. Then, it is said that the German bank agents in London are given several days credit to enable them to pay a higher price for bar gold than would be possible if the exchange rates were strictly followed.

It is by working on these artificial levels that Continental nations protect or increase their gold reserves, as the case may be ; as a result we are constantly puzzled to discover what constitutes the real specie points, and until some person is clever enough to devise a remedy, all we can do is to take the average as approximately certain and leave it at that. 


\section{CHAPTER V \\ "FOREIGN EXCHANGE" QUOTATIONS, AND THE " COURSE OF EXCHANGE"}

In this chapter we propose to explain a part-a very small part-of the matter dealt with by that redoubtable person, the City Editor.

In the Money Article there appears daily a list headed, "Foreign Exchanges," and this is supplemented twice a week, every Wednesday and Friday, by a second table, called the "Course of Exchange." The quotations contained in these tables seem to be looked upon by the average man somewhat in the same way as the small boy regards the signs of the Zodiac-they are incomprehensible. However, there need be no mystery about the rates if the principles upon which they are based are systematically investigated; and in the hope that the mastering of these exchange technicalities may lead the student henceforth to regard the Money Article as an attractive feature of his newspaper, we proceed upon another stage in our enquiry.

\section{Rates of Exchange.}

The following is a specimen of the table published daily; it is taken from The Times of 17 th July, 1914, and generally appears with two other columns giving quotations for the two previous days. In a general way, the extra quotations are considered necessary for the purpose of comparison, but as we are not interested just now in previous rates, the columns in question are replaced by one giving some explanation of the currency of the respective countries, which will perhaps be more useful to the beginner until he has had the opportunity to familiarize himself with the daily quotations. 


\section{FOREIGN EXCHANGES.}

\begin{tabular}{|c|c|c|}
\hline 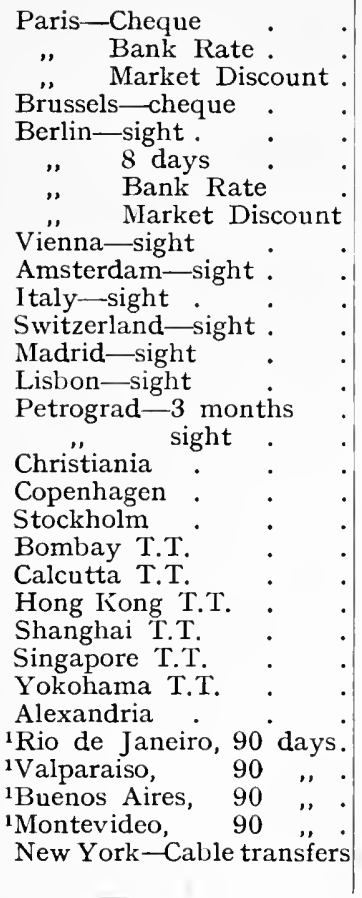 & 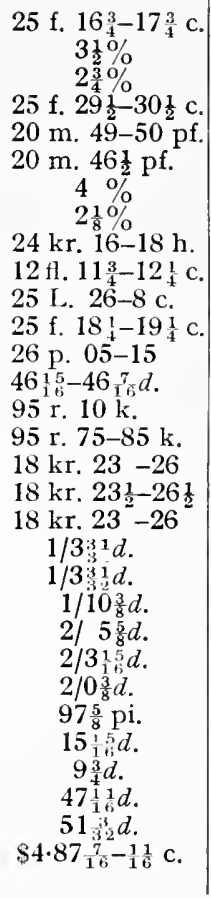 & 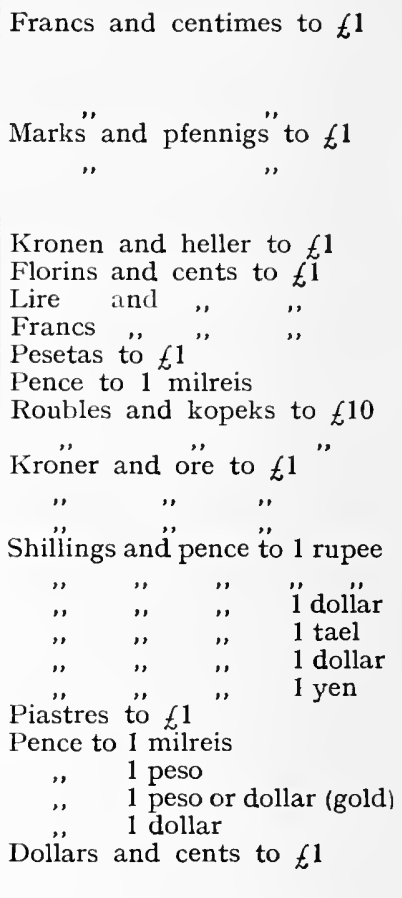 \\
\hline
\end{tabular}

1 These rates are telegraphed on the day preceding their receipt.

The rates here given are those in force on the various Bourses for bills or cheques on London, and are cabled to London from the centres named each day. With few exceptions they represent the amount of foreign money which will be paid for one sovereign, and a useful point to remember in exchanging sterling is, that where prices are quoted in foreign money to $£ 1$, high rates are favourable to Great Britain, low rates are unfavourable. For example, take the first quotation in the table. Here we have the value of a sovereign in Paris in francs and centimes, and if we want to buy a bill in francs with our sovereign, the 
higher the quoted rate, the cheaper will be the bill, while if we have a sterling bill to sell, the same rule will apply. All this sounds rather like a paradox, and it certainly is confusing at first sight, but a moment's reflection will make the matter quite plain.

Let the reader imagine he is on the market with one sovereign in his hand, and desires to change it for francs: obviously the larger number of franc pieces he is able to obtain for his piece of gold, the better off he will be in France. Conversely, if he is in London and desires to buy French currency to send to France, the higher the rate quoted the more francs he will obtain for every sovereign he puts down. Say, in response to an application the money changer quotes Fcs. 25.16 for the sovereign, and the holder of the latter coin being gifted with strong persuasive powers, finally prevails upon him to give Fcs. 25.20 for the possession of the coveted gold piece, it is plain the higher rate is the better of the two, for in receiving 25 francs, 20 centimes, the receiver has 4 centimes more than if he had allowed the sovereign to change hands without any bargaining. There is thus no difference whether you are buying francs in London or selling sterling in Paris; the higher rate is still the better.

The reverse, of course, is true if we put ourselves in the shoes of the Frenchman who is exchanging francs and centimes for sovereigns; in his case the fewer francs and centimes he pays for the pound sterling, the better will be the rate; if he gives only Fcs. $25 \cdot 16$ for $£ 1$, that is a more favourable rate to him than Fcs. 25.20. However, for the moment we are considering ourselves as the debtors buying bills in the foreign currency, and bearing in mind that high rates are in our favour, while low rates are in favour of the foreign centre, we can take the rule as applicable to all the rates down to and including that of Madrid.

But let us beware of traps, of which this list contains a plentiful supply. When we look at the Lisbon quotation, 
we find the price given in pence to the Portuguese milreis, and to this rate the above-mentioned mnemonic cannot apply. We must therefore re-state the rule by reversing it, and this is how it appears: when rates are quoted in shillings and pence to the foreign units, high rates are unfavourable to us, low rates are favourable. This, again, is easily proved. The Lisbon rate before us is $46 \frac{1}{15} \mathrm{~d}$., which will be the requisite number of pence to buy 1 milreis: if the quotation were $45 \mathrm{~d}$., it would be more favourable, since we should then pay only $3 \mathrm{~s}$. $9 \mathrm{~d}$. for each milreis bought, whereas in the first case the seller would charge nearly 3s. 11d. for the coin.

With Petrograd we revert to the former rule, and high rates are in our favour, while low rates are against us; but there is a peculiarity about the Russian quotation which calls for explanation.

In Russian exchange, rates are always quoted so many roubles and kopeks to $£ 10$, so that if we wanted to exchange sovereigns for roubles, according to the figures in our table, and leaving time out of the question, the Russians would pay Rbls. 95.75 for $£ 10$, which, of course, is only another way of quoting Rbls. 9.5 for $£ 1$.

The quotations for Christiania, Copenhagen and Stockholm, present no difficulties: in each case the more of the foreign currency we can get for the pound sterling, the better it is for us.

When we come to the Oriental countries, India, China, Japan and the Straits Settlements, we find another variation. All rates are quoted in shillings and pence, and indicate the price which will be charged for the local coin on the centres named; consequently the fewer pence we pay in England for the foreign unit, the more advantageous it will be. Then we find Egypt following the more general method, and quoting piastres to one sovereign, while the South American centres all quote in pence. Finally, we get to New York with the familiar dollar and cents to the sterling. 
It adds to the beginner's complexity to find that with most centres there is what we might term a "doublebarrelled "quotation. Where this is the case, the price represents two limits-buyers and sellers. Look at the Paris cheque rate, which shows that you could find buyers on the Bourse at Fes. 25.163, and sellers at Fcs. 25.173 for a cheque drawn on London, payable there immediately the British creditor receives it from the debtor in France. As there is a difference of 1 centime between the two rates, it is apparent that the ultimate price at which dealings are settled will depend upon the extent of the operations and the amount of bargaining that takes place: demand and supply, and all the factors governing other commodities will come into play. In the absence of demand, or if there is a plentiful supply of bills, the sellers will soon be glad to let them go at the lower rate, while if the supply is less than the demand, the persons seeking to remit will compete to buy the bills, and the higher price will be paid. This bears out the contention upon which we have laid stress, that the price of debts is subject to the same influences as those governing the price of other commodities.

It seems hardly necessary to add in regard to these rates, that if you are a buyer of sterling, naturally you want to give as few francs and centimes, or marks and pfennigs as possible for $£ 1$, and if you happen to be the seller of sterling, it is to your interest to obtain as many of the local coin as possible for every sovereign sold.

Some people say that the double quotation in the table indicates the variation in rates between bank bills and mercantile paper; but this is not so, and the error arises from confusing the rates quoted in the "foreign exchanges" " table with those given in the bi-weekly "course of exchange." The only meaning which can be read into a rate, such as the Paris cheque, in the "foreign exchange" quotations, is, that on the day on which it was current, the price of a cheque in Paris, drawn on London was 
Fcs. $25 \cdot 16 \frac{3}{4}$ to Fcs. $25 \cdot 17 \frac{3}{4}$, the extent of the margin between the two quotations depending upon the volume of the operations, and whether buyers or sellers are in the majority.

There is a variation in the rates quoted by Berlin. First we have the "sight" quotation, which of course is only another way of giving the "cheque" rate. To all intents and purposes the cheque and sight rates are the same: the sight draft is payable immediately at sight, and the cheque is payable on demand, consequently it makes no difference to the creditor which form of remittance he receives.

Berlin also quotes an eight days' rate, which means we have to make an allowance for the time in the price. We can sell a sight draft in Berlin drawn on London for Mks. 20 49 pf., but an eight days' sight draft will return us only Mks. 20 $46 \frac{1}{2}$ pf., because the person to whom it is sent is under the necessity of presenting it for acceptance, and after the bill is accepted he has to wait eleven days before he can obtain his money, the extra three days being granted to the acceptor of the bill in accordance with the provisions of Section 14, subsection 1 of our Bills of Exchange Act. The difference in the rate, $3 \frac{1}{2}$ pfennigs, represents the interest on the deferred payment, and this difference varies in accordance with the local rates of interest in the centre upon which the bill is drawn. The lower the rate of interest, the more marks and pfennigs will go to the pound sterling.

Vienna, Amsterdam, Italy, Switzerland, Madrid and Lisbon, all quote the sight rate, but Petrograd, as if to relieve the monotony, has two rates, sight and three months. The sight quotation is Rbls. $95.75 \mathrm{k}$. to $£ 10$, but the price for a three months' bill is given at Rbls. $95 \cdot 10 \mathrm{k}$., or nearly two-thirds of a rouble less, the difference being the interest allowed to the buyer for the time the money is in the hands of the sellers before the draft is paid.

The Scandinavian rates call for no comment: they are all sight rates. 
Some difficulty may be experienced when we get to the Eastern rates. We have six centres all quoting 'T.T. rates, i.e., the prices for telegraphic transfers. These rates are cabled daily to the offices of the various Indian and Eastern banks, from which the Press gets the quotations which we see published.

The quotations all mean the sterling selling rates for rupees, dollars, taels, etc., for homeward remittances by wire. If a man in Yokohama, for instance, owes a debt to a merchant here, and the T.T. rate is 1 yen $=2 \mathrm{~s}$., then for every yen paid to the Bank in Yokohama, 2s. will be paid to the creditor in London as soon as the Bank's London branch has received and decoded the cable.

No time is specified for piastres in Alexandria, but the quotation is for sight drafts.

The four South American quotations are for bills drawn at ninety days' sight, and they all show the number of pence to be calculated as the equivalent of the respective currency units in the centres named when it is a question of sending the bills payable ninety-three days after sight, the additional days being the "days of grace" allowed by British law.

The New York quotation is for cable transfers, which, as the reader will no doubt perceive, are merely the American equivalent for telegraphic transfers, and expresses the number of dollars and cents which will be charged for each sovereign payable in London on receipt of the cablegram from New York.

As a matter of fact, New York rates are usually honoured with a special table to themselves. Owing to New York's lying so far west, there is a difference in time of about five hours-it is noon in London when it is 7 a.m. in New York; consequently the work of the City editor of the great dailies is well advanced, and most of the other financial matter has been arranged and printed before the New York rates are received, which necessitates their being rushed into a separate page at the last available moment. 
The importance of all New York quotations renders it imperative to give the very latest rates, and in this respect they differ from the South American rates, which, although appearing in our list on Friday, 16th July, 1914, are really the prices current on the various markets on the previous Wednesday evening; they are thus a day old when received. New York quotations are those for the previous evening.

The following may be taken as a specimen table of New York rates-

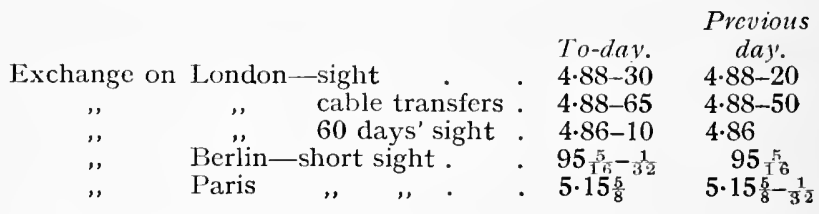

The "sight" exchange is clearly the dollars and cents to the pound sterling, payable at sight in London on presentation of the bill by the receiver to the person or bank upon which it is drawn. The cable transfer rate, as we have seen, is the selling price in New York for the sterling equivalent to be paid in London as soon as the message has been flashed across the wires to the paying banker. The sixty-days' sight quotation indicates that the draft is not payable in London in sterling until sixty-three days after the draft has been received, presented and accepted for payment.

The cable remittance commands the highest price, because it is for prompt payment: in the sixty days' sight rate we have made an allowance for interest, therefore it is sold at the lowest price.

The Berlin short sight rate, and the Paris short sight rate, call for little explanation. In each case " short sight" means that a draft is payable eight days after sight, and the Berlin quotation-95 $\frac{5}{16}$, shows the number of cents which will be given in New York for a bill for 4 marks, payable in Berlin. The Paris rate- $5 \cdot 15 \frac{5}{8}$, means that 
1 dollar in New York is exchanged for Fcs. $5 \cdot 158$ payable in Paris.

\section{Short and Long Exchanges.}

Before leaving this table it may be well to refer to the three months' rate, to which we have as yet made only a passing reference. This brings us to a part of the list we lave left unexplained: we refer to the bank rate and market rate of discount.

Rates like the Paris cheque and the Berlin sight, are called the "short exchangc," while the three months' rate, as quoted in Petrograd, is termed the "long exchange," and the rates of discount enable us to trace how the quotations are arrived at. Given the short rate, we can always find the long rate, and vice versa. To work these out, we may imagine we are on the Paris market. If we have to remit from France to settle a debt in England, and decide to send a cheque, we will pay, say Fcs. $25 \cdot 1675$ for every sovereign, or claim to a sovereign, the Paris banker sells : by remitting this cheque we place in the hands of the British creditor the power to obtain payment for the debt at once, but suppose we elect to send him a three months' bill, what governs the price we must pay for it ? It is plain that the creditor will be obliged to wait three months before he can cash the draft; consequently, we are bound to put him in such a position that he will not lose over the

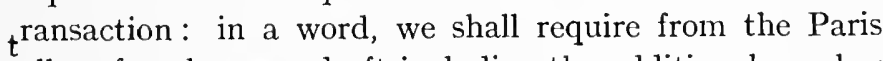
eller of exchange a draft including the additional number of francs that will recompense the creditor for the time he is out of his money. As the Paris dealer gets the money three months before his correspondent in London has to pay the bill, in purchasing three months' paper, or long exchange, we get it at a lower price than that paid for the cheque or short exchange.

In the case of Paris, however, our table does not give the long rate, so, assuming we are buying bank paper, we calculate the rate in the following way. 
The short exchange, Paris on London for bank paper we see from our table is given as $£ 1=$ Frs. 25·1675. Now for a bill payable three months from the date of issue, 16th July, we must pay the cheque rate, less three months' interest, and as we are dealing with bank paper, we take the market rate of discount ruling on the centre upon which the bill is drawn-London, which on the day in question was $2 \frac{1}{8}$ per cent. Over and above this charge we have to make an allowance for stamp duty on the bill, which will usually be about half per mille, and in many cases we also add a small amount for contingencies-the compensation allowed to the buyer of a bill for the risk he takes on the signatures of the drawer, acceptor and sometimes indorsers of the bill. From these details we can now set out our calculation-

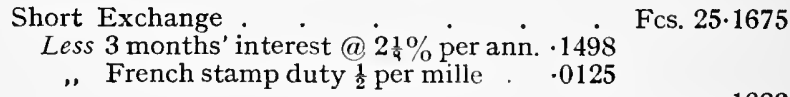

the long exchange, Paris on London.

Fcs. $25 \cdot 0052=$

As regards the amount chargeable for contingencies, this usually varies (it may be one per mille, or even less), as bankers will frequently cut rates if they are keen on doing business.

We see, then, that when drawing from the foreign city, the three months' rate on London is calculated from the short exchange, less interest at $2 \frac{1}{8}$ per cent, our market rate on the date the business is done, plus cost of the bill stamp and often a small consideration for contingencies. Similarly, if we have a three months' rate, we can always find the short exchange by adding instead of deducting three months' interest at market rate.

Longer usance can be calculated in the same way, but with this difference. If it is desired to find the cost of a four months' or six months' bill, we calculate the interest for the period at a rate slightly in excess of the $b a n k$ rate 
ruling in the centre upon which the bill is drawn, and in all cases it will appear that the longer the period of payment of the bill is deferred, the cheaper will be the price to the person purchasing it with British sovereigns in the foreign market.

Bank Rate, as is well known, is usually higher than market rate; therefore if ordinary trade bills are remitted from Paris, to find the long exchange, interest will be calculated at our Bank Rate, as trade paper is not considered such a good security as bank bills.

The student may all this time be wondering why we take the rates of discount ruling in the country upon which the bill is drawn, instead of the rates quoted in the country of origin. The reason is, that the person to whom the remittance is sent may desire to turn the bill into cash by getting it discounted, and the rate which the banker or broker would charge him is the one in existence on his own market; consequently, if the holder of the bill sells it under discount he is presumed to be in exactly the same position as he would have been had we remitted him a cheque or sight draft from Paris, or whatever the foreign centre is.

The reverse operation, drawing on Paris from London, will be shown after we have discussed the "Course of Exchange."

\section{Course of Exchange.}

The second table in which we are interested is known to the newspaper world as the "Course of Exchange" ; in banking parlance it is called the "On 'Change Table." This, as we mentioned earlier in the chapter, is published twice a week, and appears in the newspapers every Wednesday and Friday. The rates quoted are those in force on the preceding day in London. Every Tuesday and Thursday various foreign exchange dealers, bankers, brokers and financiers meet within the hallowed precincts of the Royal Exchange, and their dealings in bills take 
place on the ground floor in the spacious hall which City workers have come to regard as the sacred domain of the five-shillings-a-week office boys, who, failing any other shelter, resort to the Exchange to eat the more or less frugal lunch which thoughtful mothers insist upon their carrying to the City each day. Practically the only paper which meets the eye of the general public is the newspaper wrappings of the mysterious parcels which daily emerge from the pockets of these diminutive City urchins.

The On 'Change Table, to call it by its vulgar name, represents the prices at which bills on the various countries have changed hands, and immediately the bargains have been recorded, the list is drawn up and issued to the Press, who publish it the next day.

In case the reader may wonder why the London quotations are not more frequently issued, we may at once say that London, being the international monetary centre of the world, has very many more bills drawn upon her than she draws on other countries; consequently, the persons interested in these "wretched, crinkled, scrawled-over, blotchy, frowsy pieces of paper," ${ }^{1}$ are concerned in a far greater degree with the rates quoted in foreign cities than they are with those settled in London.

The table which follows is also taken from The Times of 17th July, 1914. The original list appeared with two additional columns of quotations, recorded at the previous meeting of the foreign exchange coterie, namely, Tuesday, 14th July, 1914, the latter being given for purposes of comparison, as with the "Forcign Exchanges" ; but here again we give in substitution of the earlier rates, a brief note explaining the meaning of the rates quoted.

There are one or two peculiarities about this table which call for attention. In the first place, we have the Dutch rate quoted in florins and stivers to the pound sterling, instead of in florins and cents, as in the "Foreign Exchanges." The writer knows of no reason why we in

1 Mr. Lloyd George's name for them. 
COURSE OF EXCIIANGE.

THURSDAY, 16TH JULY, 1914.

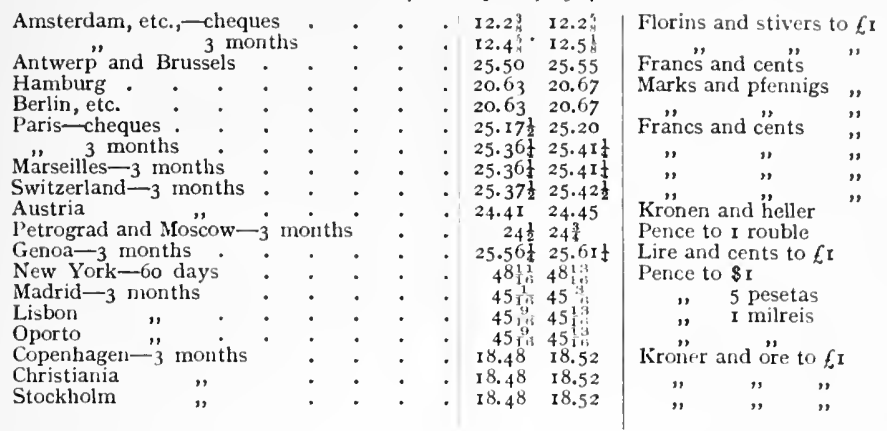

London continue to quote Amsterdam in this way; by quoting the fractions in stivers, we are years behind the times. However, apart from the awkwardness of having a different quotation in Holland, there is no difficulty about the matter; it is simply a question of remembering that with the London rate on Amsterdam 20 stivers go to the florin, while with Amsterdam on London, 100 cents equal 1 florin: the stiver is therefore worth $\mathbf{5}$ cents.

The rates for Petrograd and Moscow, it will be noticed, are given in pence to 1 rouble, while for New York the quotation is in pence to one American dollar. Then we have the Madrid rate in pence to 5 pesetas, instead of pesetas to $£ 1$ sterling as in our former list.

With each country it will be seen we have two rates given, both with the quotations for cheques and those for three months' bills. Unlike the prices in the "Foreign Exchanges" list, the rates given in the "Course of Exchange" for the long exchange, indicate the current quotations for two different classes of paper. Where the quotations are in foreign units to the pound sterling, as francs to $£ 1$, the first rate will be the price of first-class bank paper, the second that charged for the ordinary trade or commercial bills. To take the first on our listAmsterdam, Fl. 12.45, is the price at which bankers' 
bills can be bought. We get only Fl. $12.4 \frac{5}{8}$ stivers for one sovereign, but if we are content with the commercial bill, we can procure Fl. $12.5 \frac{1}{8}$ stivers for the same amount of British currency. As we thus get a higher rate for the latter class of paper, we see that it is cheaper, and the cheapness lies in the fact that it is inferior to the bank paper.

So much for the long exchange. The reason for two quotations being given for the short exchange is due to the fact that the rates include all bills within ten days of their maturity, hence, drafts which have anything up to ten days to run are of less value than the cheque or sight bill, which is due on demand: the slight allowance for interest causes the difference between cheques and the drafts not quite due.

It must not be forgotten that in the Course of Exchange we are operating from London, and not from the foreign centre, which has for effect that the rates for the long-dated paper are higher than those for the short exchange: that is to say, we obtain for each sovereign more florins and stivers, francs and centimes, marks and pfennigs, etc., when buying bills payable three montls hence, than we do when buying cheques or short-dated paper payable practically on demand.

When scanning the Course of Exchange one other point has to be borne in mind, that is, with rates quoted so many pence to the foreign currency unit, the position is reversed. With Petrograd, for instance, where we have pence to the rouble, the first quotation, $24 \frac{1}{2} \mathrm{~d}$., is the lower rate and is the price for commercial paper, but the second rate, $24 \frac{3}{4} \mathrm{~d}$., is the higher price quoted for bank paper. From these explanations, it is easy to see that when London quotations are in the foreign currency they are cheaper when they rise, and dearer when they fall: but when we quote rates in sterling, such as pence to roubles, pence to dollars, pence to milreis, etc., they are cheaper to us when they fall and dearer when they rise. 
In examining the "Foreign Exchange" list, we saw how to calculate the long exchange in Paris : to make the matter quite clear, we will work out one or two examples from the Course of Exchange.

In practice, the person who receives a three months' bill will not keep it longer than he can help, but will get a banker to buy the bill, that is, discount it for him, and the rate at which the banker discounts the two classes of paper quoted in our table, accounts for the difference in price between a bank bill and a commercial bill. Bank paper is always discounted at a finer rate than trade paper ; in times of monetary stringency or political upheavals, it is obviously better to hold the former class of security. Most dealers in discounting a trade bill estimate the standing of the parties to the instrument not to be so good as that of a first-class banker; consequently a price will be charged to cover the discounter for the increased risk.

Let us take the Paris long exchange (three months) and endeavour to see how it works out.

The rate for bank paper, London on Paris, is given as Fcs. 25.3625, On referring back to the foreign exchange list we see that Paris quotes its market rate at $2 \frac{3}{4}$ per cent. ; therefore we must take three months' interest at $\mathbf{2}_{4}^{3}$ per cent., and we get the following simple calculation.

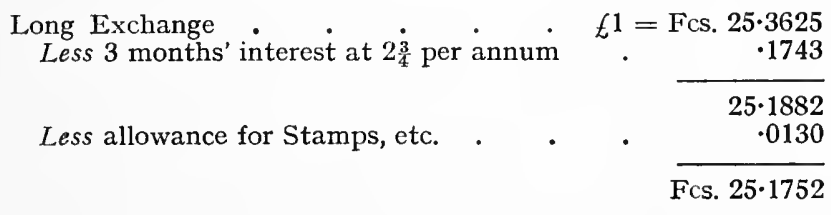

This may be taken to show that if the person to whom we send a three months' bank bill on Paris gets it discounted, he will obtain practically the same amount as if we had sent him a cheque or a bill with only a few days to run.

Now let us calculate the rate for dealing in commercial paper.

5 -(1525) 
The quotation in our table for commercial bills was-

Long Exchange . . . . . $£ 1=$ Fcs. 25·4125

If our creditor in Paris sells this bill, he will be charged discount at the Bank Rate in France, viz.--

$3 \frac{1}{2} \%$ per annum for 3 months $\quad$. $\quad .2223$

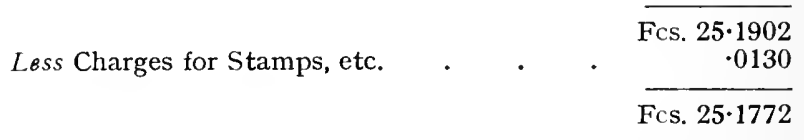

By comparing the outturn of these two bills, it will be seen that the buyer of bank paper is charged very little more for the extra security he obtains, although in times of stress the difference between the two quotations will tend to be greater. 


\section{CHAPTER VI}

\section{CONTINUES THE DISCUSSION ON LONG AND SHORT EXCHANGE, AND SHOWS HOW "TEL QUEL" \\ RATES ARE CALCULATED}

IT will be useful in this chapter if we summarize the rules for calculating long and short exchange.

When dealing in London, the long exchange can always be calculated where the cheque rate or short exchange is given. To the short rate we add three months' interest at the discount rate ruling on the centre upon which the bill is drawn, i.e., the market rate or bank rate, according to the class of paper we are buying or selling as the case may be; to this we add one-half per mille for foreign stamp, and, where necessary, a small amount by way of insurance on the joint security of the parties to the bill, acceptor, drawer, and endorsers, if any.

Where the three months' rate is given in the London Course of Exchange, the short exchange may be found by deducting the above-mentioned charges from the long rate instead of adding.

When we are operating from the foreign centre, Paris, for instance, we find the long rate by deducting from the sight rate the three months' interest, at London market rate of discount for bank paper, and at the Bank of England rate for commercial paper. The stamp duty and other small charges are, of course, also deducted.

Conversely, if the short rate, Paris on London, were not quoted, it could easily be found by adding the three months' interest and charges to the long rate.

Then we come to the rates which might be termed the "Bridge of Asses" in the foreign exchanges-the rates quoted in pence. These rates seem to be an everlasting source of trouble to people who are not accustomed to the mental gymnastics which are part and parcel of the 
exchange dealer's training. A little explanation will make matters clearer.

Suppose we are operating from Lisbon on London, and the short rate is $47 \mathrm{~d}$. to one milreis, to obtain the long exchange we work rather differently from the method shown in our other rules. Let the reader imagine he is in Lisbon and desires to remit to London. It is apparent that he will want more pence for each milreis he hands over to the seller when it is a question of a three months' bill, than if he buys a remittance payable on demand. To get the long rate, then, we must add the charges to the short rate instead of deducting them, as we did when drawing from Paris on London.

The rules regarding market rate of discount and Bank Rate remain the same.

$$
\begin{aligned}
& \text { Example- } \\
& \text { Sight Rate. } \\
& \text { Plus } 3 \text { months' Interest @ } 3 \% \\
& \text { our Market Rate } \\
& =47 \mathrm{~d} \text {. } \\
& =\cdot 35 \\
& =47 \cdot 35 \text { pence }
\end{aligned}
$$

which, obviously, is equivalent to stating that we pay less for the bill at three months.

When drawing from London on Lisbon, as rates are also quoted in pence to 1 milreis, the calculation is based on the same argument, and the buyer in London who has to remit, say 100 milreis to Lisbon, will pay fewer pence for a three months' bill than he would were it necessary to send a sight bill. Thus, it is plain, that to get the sight rate he would add charges to the long rate, for he must pay more pence for a bill which enables his creditor in Portugal to obtain the money on arrival, than if that creditor had to wait three months for his money.

Example-

In drawing from London, we may take the

3 months' rate on Lisbon for trade bills as $=46 d$.

Add 3 months' Interest at Lisbon Bank Rate, say, $5 \%$

$$
\begin{aligned}
& =\frac{\cdot 57}{46.57 \text { pence }}
\end{aligned}
$$


approximately $46 \frac{1}{2} \mathrm{~d}$., which will be the sight rate on Lisbon, showing that we pay more for this bill than for the draft at long exchange rate.

Finally, with all centres there is the question of the bill which has less than three months to run, and the one which has more than three months to run.

To take the latter case first, as the terms exceeds three months, it is customary for the seller of the bill to reduce the price by allowing the buyer a rate of interest in excess of the foreign Bank Rate. For example, if the short rate on Berlin were Mks. 20.50, the German Bank Rate 3 per cent., and the period for which the bill were drawn, four months, the seller of such a draft in London, in calculating long exchange, would probably take the Bank Rate at $3 \frac{1}{6}$ per cent. or $3 \frac{1}{8}$ per cent., that is to say, in adding the charges on to the short rate, he would calculate four months' interest at $3 \frac{1}{16}$ per cent-3 $3 \frac{1}{8}$ per cent., instead of 3 per cent. per annum.

In the former case, suppose one month of the period on a three months' bill has already elapsed, some allowance for the bill, which is now due in two months' time, must be made to the seller, who will promptly fix the matter by charging the buyer interest for one month at Bank Rate, or thereabouts.

The following examples will explain the method of reasoning-

We have a 3 months' bill on Berlin for Mks. 1,500: Bank Rate in Berlin, according to our Foreign

Exchange list, is $4 \%$ : to the
One month's Interest at $4 \%$ must be added

M. 1,500

which makes the bill . . . . . M. 1,505

M. $1,505 @$ exchange of M. $20 \cdot 63=\overline{\hbar 72 \cdot 952}$

which would be the cost of the bill for M. 1,500 drawn on Berlin.

\section{"Tel Quel"}

But we have another way of arriving at the same result for a bill such as this. There is no price quoted for a two 
montlıs' bill, so we make what is called a tel quel, or net rate. How the expression has crept into our market jargon it is hard to say: some brokers hold that the term should be tale quale, a corruption of the Latin talis qualis, meaning unchanged, or, as we understand it, that the actual rate of the bill is not affected, and in view of the fact that the original exchange of the three months' bill is not altered, the hypothesis would seem to be justified.

The tel quel quotation is adjusted in the following manner-

On the basis of our previous calculation, take interest at 4 per cent. per annum for one month $=\frac{1}{3}$ per cent. ; one-third per cent. on M. $20 \cdot 63=\cdot 06876$, and the rate can now be shown as-

$$
\text { Minus } \begin{array}{r}
\text { M. } 20 \cdot 63 \\
.06876 \\
=\text { M. } 20 \cdot 5612
\end{array}
$$

which is the tel quel rate for M. 1,500, and taking M. 1,500 at M. 20.5612 we find the answer to be $£ 72 \cdot 952$, which is precisely the same result as for the other calculation.

We have now investigated very thoroughly the principal market quotations for bills, and henceforth the student should have no great difficulty in regard to the actual rates, but before bringing this chapter to a close, it is fitting that we should complete our survey of the money article as far as it affects the foreign exchanges.

In The Times of 17th July, 1914, the City Editor made a few comments on the exchanges, and it may be of interest to us to examine the rates to which his remarks applied. He says-

"Following an advance in the Rio exchange to $15_{16}^{15} \mathrm{~d}$., Brazilian bonds were a good market."

Then later-

" On 'Change the rate for bills on Germany moved against this country. Italian currency improved, and Spanish and Portuguese depreciated slightly in value. 
Paris cheques were dealt in at $25 \mathrm{f} .17 \frac{1}{2} \mathrm{c}$. to $25 \mathrm{f} .18 \mathrm{c}$.; and German cheques at $20 \mathrm{~m}$. $49 \mathrm{pf}$. to $20 \mathrm{~m}$. $51 \mathrm{pf}$."

Now what does all this mean?

The first item of news refers to the fact that Rio exchange had advanced one-sixteenth of a penny over the quotation for the preceding day: in other words, the seller of milreis in Rio de Janeiro could get $15 \frac{7}{8} \mathrm{~d}$. for a ninety days' sight bill on the 15th July, but by waiting until the 16th he was able to obtain $15_{16}^{1 \frac{5}{6}} \mathrm{~d}$. for each milreis ; further, the prospects of a steadier exchange encouraged dealing on the stock markets in Brazilian bonds. The prospective issue of a loan on the British market also strengthened exchange, since the dealers were aware that the effect of the flotation of a loan on the London market would be to turn rates against London.

By a reference to the Course of Exchange on page 51 it is easy to see that the value of the mark on the London market had declined from $20 \mathrm{~m} .64 \mathrm{pf}$. on 14 th July, to $20 \mathrm{~m}$. 63pf. on 16th July. This means that fewer marks and pfennigs were procurable for one sovereign on the latter date, and the rate is consequently unfavourable to the buyer of mark bills; moreover, the quotation tends to drive home the lesson we have been trying to convey, that with rates quoted in the foreign currency they are moving against this country when they recede.

The comments on the Italian, Spanish and Portuguese currency may well call forth the remark that "in foreign exchange rates by sweet contraries go." By saying that Italian currency has improved, the writer of the Money Article means to convey to us that the rate has gone against London, for the three months' rate on Genoa has dropped $1 \frac{1}{4}$ centesimi since the previous meeting of the exchange dealers, i.e., from 25 Lr. $57 \frac{1}{2}$ c. to $25 \mathrm{Lr}$. $56 \frac{1}{4} \mathrm{c}$. : on the other hand, "depreciation" in the case of the Spanish and Portuguese quotations is taken to indicate that those rates have moved in our favour-only slightly on this particular occasion as it happens. As we have seen, 
these rates are given in pence to the pesetas and milreis respectively, Madrid on the 16th July being quoted $45_{16}^{\frac{1}{6}} \mathrm{~d}$. for five pesetas, as against $45_{\frac{3}{16}} \mathrm{~d}$. on the 14 th July, and Lisbon $45 \frac{9}{16} \mathrm{~d}$. for one milreis, as against $45 \frac{5}{8} \mathrm{~d}$. over the same dates, which shows that on 16th July both currencies were cheaper to buy, the rate on Madrid marking a gain of $\frac{1}{8} \mathrm{~d}$., and that on Lisbon, $\frac{1}{16} \mathrm{~d}$. in favour of the buyer. These figures thus serve to illustrate the fact that when rates, as in this case, are quoted in the home currency, they are cheaper when they fall, or " depreciate," as the Editor of The Times calls it.

The French and German cheque dealings need no explanation; the reference simply means that sales and purchases of exchange were made at prices within the range of the rates mentioned.

The influences which cause the variations in the quotations have, so far, not been explained, but as that part of the subject is somewhat complex, and necessitates our investigating the connexion of Bank Rate with the foreign exchanges, it may very well form the topic for our next chapter. 


\section{CHAPTER VII}

FAVOURABLE AND UNFAVOURABLE EXCHANGE.

THE

CAUSES OF THE FLUCTUATIONS IN THE

\section{FOREIGN EXCHANGES ANALYSED}

In the course of our enquiry we have demonstrated that with the debts between two countries exactly balanced we have what is known as the par of exchange, a state of equivalence which rarely exists, but that all the same, we have fixed a point with the gold standard countries which is taken to record par.

When we apply this to bills of exchange, which are the outward and visible sign of indebtedness between nations, we take it to mean that a bill for $£ 100$ on France, for example, would on any particular day, sell in London for $£ 100$, no more and no less, and that a similar state of affairs would exist in France. With France, the par of exchange, as we know, is $£ 1=$ Fcs. $25.22 \frac{1}{2}$, and if the debits and credits between the two countries were at any time equal, a bill of exchange for $£ 100$ would be worth Fcs. 25221 in either country. When, however, the balance of indebtedness is against France, that is to say, she owes us more than we owe her, exchange will be below par, that is at a discount. Conversely, if England's debts to France are greater than her French credits, exchange will be above par, and at a premium.

The true effect of this can easily be seen by referring to the settlement of debts by means of bills of exchange.

When our exports to France exceed our imports from that country, bills of exchange drawn on France will be in excess supply here, consequently the bill for Fcs. $2522 \frac{1}{2}$ will fetch less than $£ 100$-it will be at a discount.

On the other hand, where our French imports exceed British exports to France, there will be a greater demand for remittances to pay for the French imports, and in 
consequence of the scarcity of paper, the bill for Fcs. 2522 $\frac{1}{2}$ will be worth more than $£ 100$ on the London market, that is, at a premium.

In practice, of course, it will be necessary to remember what we have said before, that the difference in the rate is not found by adding to or deducting from the bill, but by altering the rate at which the exchange is calculated. For example, in the latter case we said the rate was at a premium, or above par, and in paying the seller of the bill the proceeds in sterling, instead of calculating the bill for

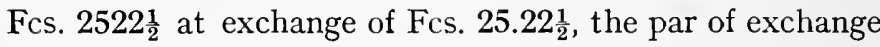
between England and France, we would allow the seller the premium by charging him a lower rate, say, Fcs. 25.20, and if the reader cares to convert the Fcs. $2522 \frac{1}{2}$ into sterling at this rate, he will see that the British equivalent of the bill will be more than $£ 100$. In the former case, the difference would be obtained by charging a higher rate, say, Fcs. 25.30, and the bill would outturn less than $£_{100}$.

\section{Favourable and Unfavourable Exchange.}

This habit of quoting a rising exchange as at a " discount," and a falling exchange as at a "premium," has in the past made confusion worse confounded, and for the sake of the exchange student, we are glad to see that the practice has of late years fallen into desuetude. But one cannot say that the present-day usage of the terms "favourable" and "unfavourable" in regard to the exchanges is less misleading.

When we find that bills of exchange drawn from London on foreign centres are at a premium, we say that exchange is against us, or unfavourable to the country. For instance, take the case we examined just now. Inasmuch as the par of exchange with France is Fcs. 25.221 to pay more than $£ 100$ in London when buying a bill for Fcs. $2522 \frac{1}{2}$, it is plain that $£ 100$ here are worth less than the fixed equivalent of French currency : hence the reason for saying the exchange is unfavourable to London. 
Similarly, if it takes less than $£ 100$ in London to buy a bill on Paris for Fcs. 25221, French exchange is said to be " favourable" to England.

The indiscriminate use of such terms is a real pitfall in foreign exchange, and a moment's reflection will show that a favourable or unfavourable exchange applied to the country is one thing, but when applied to individuals, it is another.

Briefly, exchange is unfavourable to a country only when that country is obliged to send bullion in liquidation of its indebtedness, and favourable when bullion is received from a debtor country. However, lest we be charged with a leaning towards the fallacies of the old Mercantile Theory, we hasten to say that this sending or receiving of bullion is important only in so far as it affects the banking situation. It is the banks which will part with the gold, and with each fall in their reserves they will tend to restrict the credits of which gold forms the basis, or, rates for accommodation will become dearer, which amounts to the same thing ; and it is easy to comprehend that any restriction in credit facilities by this means will check commerce, and so ultimately prove adverse to the country. It will be perceived that we refer to the raising of the rate of discount as a means of stopping the outflow of gold. On the other hand, with a reasonable influx of gold, the banks' reserves reach that point when a low bank rate can be put in operation, and it follows that with cheap capital, there is an impetus to a country's trade and production.

As far as individuals are concerned, we may say it is the debtors to whom the terms "favourable" and "unfavourable" apply: they must buy the bills to send to their creditors, and the question of how much of the foreign currency units they can get in exchange for each unit of the home currency is of vital importance to them; and where the buyer of a bill can procure Fcs. 25.30 to the pound sterling, that rate will be more favourable to him than if the seller parts only with Fcs. 25.20 per sovereign. But, obviously, 
what is favourable to the merchants who have to buy bills in London, will be unfavourable to those who have money to receive from France, since this second class will be the sellers of the bills which the former class buy, and the more francs and centimes surrendered by the seller for each sovereign received, the more unfavourable will be the rate of exchange.

This, by the way, is the usual illustration of the manner in which two debts are cancelled: the importer pays his foreign creditor, and the exporter obtains payment from the foreign debtor. We may be pardoned for again referring to the subject, but a little repetition will serve to fix the principles in the student's mind. Exporter A, we will suppose, has sent to France goods to the value of Fcs. 1,000, while importer $\mathrm{B}$ has received from Paris produce of a similar value. A draws a bill for Fcs. 1,000 on the merchant in France, and finds an easy way to obtain the equivalent by selling it to $B$, who is under the necessity of remitting that sum for the French imports. Thus, it is to A and B that the terms "favourable" or " unfavourable" will apply, the one being the receiver and the other the remitter.

From these remarks it follows that to the buyer of the bill in this country, high rates are favourable, low rates unfavourable, when quoted in foreign units to the pound sterling; but, when the rates are quoted in shillings and pence to the foreign units, high rates are unfavourable and low rates are favourable. ${ }^{1}$ For selling paper the maxim is the reverse: with rates quoted in foreign money to the pound sterling, the seller must bear in mind that low rates are favourable, high rates are unfavourable; and, if he is selling bills based on rates which are quoted in shillings and pence to the foreign units, high rates will be favourable, low rates unfavourable. The following rhyme, the product of the brains of one engaged in this business, is recommended as a useful mnemonic.

1 Cf. Banking and Currency (E. Sykes), page 218. 
Just sing this little chorus, And sing it every day:

"That higher rates are for us, And low the other way."

That is, when quoting units To every sterling pound;

But with pence to units foreign, It's the other way around.

For then you'll sing your chorus Every day, until you die:

"That the low rates will be for usThose against us will be high."

Before leaving this part of the subject, it may be well to refer to what is in the minds of the economists when they say that an unfavourable exchange is an encouragement to exporters and a discouragement to importers.

It has been remarked that when the value of the imports from a country exceeds the value of the exports to that country, bills are at a premium. It follows, therefore, that the greater the amount of the premium, the higher will be the profits exacted by the exporters. They draw bills for the cost of their shipments to the foreign country, and in selling the bills obtain the premium in the rates of exchange. Plainly, this indicates a diminution in profit to the importers, who not only have to pay the invoice price of the goods, but also pay a premium for the remittances they require to send to the foreign exporter.

In practice, the exporters are hardly likely to obtain the full extent of the premium quoted; a proportion, sometimes the whole of the premium, would go to the bankers who negotiate the bills.

To complete the examination of this part of our subject, it is important to refer to the fluctuations in the rates of exchange.

\section{Fluctuations in Rates of Exchange.}

In Chapter IV we saw that a nominal par of exchange exists between two countries which have the same metal 
as the basis of their currency. Some reference was also made to the specie points, which mark the limits within which the premium on bills rises or falls. Between these points exchange will fluctuate, sometimes above, sometimes below, the par of exchange, and the best statement of the theory the writer remembers to have seen, is that laid down by Bastable in his Theory of International Trade. ${ }^{1} \mathrm{He}$ concludes that the limit of exchange fluctuations, in either direction, may be fixed by the cost of the passage of specie, and the statement is summarized as follows-

"The upper limit of exchange fluctuations is par, plus the cost of transmitting specie: the lower limit par, minus the cost of transmitting specie,"

and twice the cost of remitting specie, as he rightly maintains, is the whole space within which fluctuations can nominally take place.

The movements which are incessant, are affected by a variety of conditions, but generally speaking, we may say they are governed by Supply and Demand (for bills), which in turn are determined by the relative indebtedness resulting from the course of trade between countries. If it were only with trade influences we had to deal, the problem of fluctuations would not be difficult to trace, but there are other elements to consider: thus we have to take account of the currency conditions in various countries. Some have a debased currency, others, supposed to be on a gold basis, are continually in the throes of a depreciated paper currency ; and, lastly, we have those countries whose money is of metal different from that of others, say, gold in one country and silver in another, and in addition to the ordinary movements in exchange, it is necessary to say how much of the silver currency shall be paid in the silver-using country in order to confer the right on a trader to receive an agreed gold equivalent in one of the gold centres-a problem of no little difficulty when we remember that it necessitates our comparing the silver

1 Page 83. 
price of gold and the gold price of silver at any particular time.

We will leave the currency problem alone for the present, and discuss the causes upon which depend the demand for and supply of bills.

In the first place we might emphasize the fact that the total indebtedness of a nation has practically no effect on the exchanges; it is only when the debts come to be liquidated that movements are apparent, and even then it will be the balance of indebtedness which will influence rates.

\section{Trade Conditions.}

Trade conditions, of course, cxercise the most potent influence upon the exchanges, since, as we have seen, it is from the exports and imports of a country, as shown by its trade statistics, that the supply of bills principally emanates. Nevertheless, in dealing with the subject from the British point of view, we must be careful to remember that we as a nation draw few bills in comparison with the vast number drawn on this country, and the reason for the excess drawings is easily shown. Merchants and financiers all over the world know that a bill of exchange on London is readily negotiable; it is in fact the recognized international medium of exchange, and, so far, the bills of no other country can claim this unique quality. Bills on France, Germany and other European nations are also drawn and negotiated, and, collectively, their number is not small, but they principally represent remittances for direct shipments of produce and manufactures from foreign countries, and are consequently used only in connexion with the trade between those countries, and hitherto they have not been able to compete with the bill drawn on London.

It must not be supposed, however, that bills drawn on London are solely on account of our own foreign trade. In reality, they are drawn in connexion with the trade and commerce of almost cvery civilized country in the 
world. Take, for example, the shipments of tea between Shanghai and New York. Payment is usually made by means of a bill on London, and if an importer in France orders coffee from Rio, or cotton from New Orleans, he will, in ninety-nine cases out of a hundred, obtain payment through the medium of the London money market. Many of the French merchants who send goods to China or Japan, will, in a like manner, finance their operations through London in preference to any other financial centre. In any important foreign commercial market the names of the London accepting bankers are as well known as in Great Britain, and the exporter has only to take his bills to a local bank to realize a better rate than for bills on, say, France, Holland, Germany, or the United States of America.

Bills on London are drawn, not only for goods, but in connexion with securities also. This was evidenced in the late rubber "boom," when bills representing enormous sums came forward from foreign capitalists who had invested money in shares, the payment for which had eventually to be made in London.

The fact of our being the only free market for gold has already been referred to, but what we might term the gold basis of bills on London is not the only reason why banks, financiers, merchants and others in the far distant parts of the world prefer to negotiate them: they buy the paper because there is everywhere a ready market for it. The bills can always be transferred to other buyers on foreign markets who want them to remit in payment of indebtedness to England or some other country. It does sound rather like a truism to say that this remarkable free market in bills on London exists because there is always a supply, still the fact cannot be explained away, and in the meantime the demand continues from every part of the world.

After this rather long peroration, it will be quite manifest that it is the export and import trade of our own and other 
countries which exercises the dominating influence on the foreign exchanges.

\section{Invisible Imports and Exports.}

Closely allied to these trade conditions, we have another important influence which affects exchanges in a marked degree: we refer to what Sir Robert Giffen described as "Invisible Imports and Exports"-_."invisible" because they are not shown in any of the elaborate Board of Trade statistics. Under this appellation are included all such items as freight and insurance, remittances for the purchase or sale of ships at foreign ports, the hire of vessels, the drawings of captains and masters of ships; expenses and remittances of foreign residents (including military, consular and Government servants) ; bankers' commissions, and so on.

Of these, doubtless the chief item is that connected with the shipping trade. Owing to the ramifications of its great mercantile fleet, Great Britain holds most of the world in fee for the carrying trade, and is, of course, a creditor for all its maritime services, although these to a very slight extent may be offset by the amount for which she is debtor for the use by her of a proportion of the foreign ships. The drawings for the purchase and sale of ships affect the exchanges in accordance with the centre from which the bill is drawn, or by what means the settlement is finally made. The drawings of captains refer to the arrangements under which the cost of re-victualling or coaling vessels is carried out. In many cases a bank at a foreign port is authorized to negotiate the bills of the captain on a London louse, and the total of these bills goes to swell the demand for or supply of paper affecting the exchanges.

\section{Foreign Residents.}

The remittances and expenses of foreign residents are, ordinarily, not of great importance; they influence the 
exchanges of the country of residence and also those of the native land when the remittances are made to and fro; the balance would be sometimes in favour of one and sometimes in favour of the other.

\section{Bankers' Commissions.}

Bankers' commissions are generally regarded as a negligible item, but as, in the writer's opinion, that idea is erroneous, brief mention may be made of them. The more important commissions are those paid to bankers by foreign governments and others for carrying out what is termed the "service of loans," that is, the paying of the foreign governments' coupons on bonds for loans issued, and attending to the multifarious duties which the issue and subsequent control of the transfer of the funds entails. It is apparent that the sums involved may, in the aggregate, amount to large figures, and when they are remitted the exchange is influenced to that extent.

More than once it has been asked how a bill can possibly be drawn in connexion with the service of these loans. A familiar example is seen in the case of international loans. Say three countries, England, France, and Germany, lend money to China, and it is arranged that the payment of coupons belonging to certain German residents shall be paid in London. To do this the London bank must be put in funds, and Germany, if desirous of so doing, can remit the amount by means of a bill of exchange purchased on the Berlin Bourse, which of course affects the exchange between Berlin and London. China, on the other hand, may at certain periods of the year arrange to put the British, French and German banks in funds for paying the service of the loans in each country. The remittance may be made by means of a telegraphic transfer or by the sending of a demand bill, whichever may be cheaper or more convenient, and in any case the transfer 
of funds from China to Europe will ultimately affect the exchanges between China and the countries named.

\section{Stock Exchange Influences.}

The mention of Chinese borrowings brings us to a very important influence on the exchanges, namely, foreign loans, but perhaps before we trace the effect of foreign loans on exchange, we had better deal with what are called the Stock Exchange influences, to which international borrowings properly belong.

The accumulation of capital in England and other European centres renders it a matter of difficulty to invest surplus funds, that is, if a relatively high rate of interest is to be obtained, and consequently, the operations carried out by bankers and the Stock Exchanges combined, frequently affect foreign exchange rates when we least expect it. The various stocks and shares are to a large extent internationalized, and the business is constantly done by the aid of telegram and cable: a slight variation in price will often mean a stream of orders to buy or sell, as the case may be, from one country to another, and as a result, the heavy demands for cheques or sight bills to pay for the heterogeneous mass of securities are at once reflected on the exchange quotations. If London has been investing in French Rentes, for example, the purchase of demand bills drawn on France to pay for the securities will depress exchange on Paris; thus, the rate for cheques on Paris may be Fcs. 25.221, but as there are so many persons desiring to remit, there will be competition for the drafts, and the sellers, emboldened by the demand, will offer only Fcs. 25.15 to the pound sterling, which is obviously an adverse rate to the remitters.

Some idea of the magnitude of the business in this country alone in foreign securities may be gathered from the following list of British investments in foreign and colonial stocks and shares- 


\begin{tabular}{|c|c|c|c|c|}
\hline \multicolumn{5}{|c|}{ British Possessions ${ }^{1}$} \\
\hline Canada and Newfou & undland & & & $373,000,000$ \\
\hline Australia and New & Zealand & . & . & $380,000,000$ \\
\hline South Africa. & . $\quad$. & . & . & $351,000,000$ \\
\hline West Africa & . & . & . & $29,000,000$ \\
\hline Straits Settlements. & . & . & . & $22,000,000$ \\
\hline India and Ceylon . & . & . & . & $365,000,000$ \\
\hline Miscellaneous & . & . & . & $33,000,000$ \\
\hline
\end{tabular}

\begin{tabular}{|c|c|c|c|}
\hline \multicolumn{4}{|c|}{ Foreign COUNTRIES } \\
\hline United States & . $688,000,000$ & Turkey & $18,000,000$ \\
\hline Cuba . . & $\quad 22,000,000$ & Egypt & $43,000,000$ \\
\hline Philippines & $8,000,000$ & Spain & $18,000,000$ \\
\hline Argentine & $269,000,000$ & Italy. & $11,000,000$ \\
\hline Mexico. & . $87,000,000$ & Portugal & $8,000,000$ \\
\hline Brazil & $94,000,000$ & France & $7,000,000$ \\
\hline Chile. & $46,000,000$ & Germany. & $6,000,000$ \\
\hline Uruguay : & $35,000,000$ & Other European. & $36,000,000$ \\
\hline Peru. & $31,000,000$ & Japan . & $53,000,000$ \\
\hline Other America & $22,000,000$ & China. & $26,000,000$ \\
\hline Russia . . & $38,000,000$ & Other Foreign & $61,000,000$ \\
\hline
\end{tabular}

The interest on these investments has a very considerable effect on the exchanges: when the payments are remitted, or coupons sent for collection, as the case may be, exchange will turn in our favour. On the other hand, as the late Viscount Goschen was careful to point out in his book on the Foreign Exchanges, a country which annually has large sums of interest to pay abroad, must import so much the less or export so much the more.

The issue of a loan on the London market will turn the exchange of the country borrowing against this country at the time the money is paid over to the foreign nation. The immediate effect is to increase Great Britain's indebtedness by the amount of the loan, but this influence may be neutralized where a large part of the proceeds is used for the purchase of British manufactures. An illustration of this is seen where a country is raising money abroad for the avowed purpose of building railways in its own territory. The lenders will make great efforts to secure in the loan agreements the insertion of clauses stipulating

1 From a paper by Sir George Paish, read before the Royal Statistical Society, December, 1910. 
for the purchase of at least a part of the constructional materials in the country in which the loan is being floated. The influence on the exchange, plainly, may be offset to the extent of such purchases.

The contention of the economists, with which we need not quarrel, is, that a loan acts in precisely the same way as an import to the lending country and an export to the borrowing country. The reverse is true when the coupons or interest on such loans is paid: the coupons will represent an export from the lending country, and are always regarded as an immediate liability of the borrowing nation. As far as the exchanges with this country are concerned, they exercise a permanent influence in our favour.

Most foreign government loans are repayable by means of sinking funds, and with each repayment of principal the effect on the exchanges will be the same as that occasioned by the export of the interest coupons, since the lending country exports the drawn bonds in exchange for the remittance of their value by the borrowing nation.

\section{Finance Bills.}

Before leaving the subject of the Stock Excliange influences we ought to refer briefly to one of the methods by which speculators raise funds to enable them to carry through operations which promise a profitable return. Here we have a case where a bill is actually drawn by a banker on his correspondent, who is also a banker, and the instrument is known as a Finance Bill. The following is a very simple instance of what occurs between London and New York.

A broker in New York sees an opportunity of making money by speculating in some of the well-known stocks or shares. He goes to his banker and arranges to deposit securities against which the banker advances him $\$ 0$ per cent. of their value, and the custom is to place these securities in the safe-keeping of one of the big Trust Companies, who will act for both parties. The banker himself, 
obviously, does not want to lock up his money for any period of time, so under arrangements previously made, he draws a bill, usually at sixty or ninety days' sight, on one of the London bankers or finance houses. He sells this bill on the New York market and thus recoups himself for the amount lent to the stockbroker. When the bill arrives in London it is accepted by the London banker or other correspondent, who has now incurred the liability to pay it at maturity if the American banker does not put him in funds in time to meet it. Needless to say, however, it is to the American's interest to see that his London correspondent is put in funds in time to meet the bill, and if by chance it is inconvenient for him to remit the wherewithal to pay the bill at due date, what he does is to draw another bill of the same kind, and again sell this on the Wall Street market, and thus procure the necessary funds to buy a demand remittance to send to the London banker.

As may be supposed, this business is carried on only between banks of high standing, and in many quarters it is thought that the commission charged for the service is not commensurate with the risk involved should a monetary crisis ensue between the date of drawing and maturity of the bills.

It will be fairly plain to the student by this time that the effect of the drawing of any quantity of these finance bills on London will be to weaken American exchange with London.

\section{Letters of Gredit.}

In referring to finance bills, we have almost imperceptibly touched on one of the most familiar influences which affect the foreign exchanges, namely, the Banking Influences. Under this heading are included all the international operations of bankers which in any way affect the exchanges.

One of the results of the extension of foreign branch banking is the increased use of credit instruments. Bankers 
finance foreign trade, and we may go a step further and say they finance the foreign traveller also. In fact, some of the fluctuations in the exchanges are the direct result of the drawing of bills under the various credits issued by bankers. Most of us know that when a person is about to take a journey abroad, he first goes to his banker and procures either a letter of credit or a quantity of circular notes. These latter when negotiated abroad are sent back to London for encashment, and there is no practical difference between the circular notes and bills of exchange drawn in the ordinary way. The same may be said about the drafts encashed by foreign bankers against letters of credit.

Travelling letters of credit and circular notes are, however, not the only form of credit which affects the exchanges: as we shall see when we come to deal with foreign bills, bankers grant letters of credit in connexion with the shipment of manufactured goods, produce or securities, and all give rise to the drawing of bills, which in one way or another exercise an influence on the foreign exchanges. Yet, taken by themselves, the sale and transfer of these bills drawn under credits cannot be said to exercise a marked effect, but with the amalgamation of existing banking interests, and the practice of setting up banks or banking agencies in the remote parts of the earth, the bills drawn under bankers' credits are beginning to constitute an item of much greater relative weight in the scale of the exchanges than was formerly the case.

\section{Arbitrage.}

Of far greater import, however, is the way the exchanges are manipulated by means of Arbitrage Operations. Arbitrage is a subject which calls for special treatment, and writers on exchange prefer to enlarge upon it in special books. We may, however, be permitted to make brief reference to it in so far as it affects rates.

A simple form of arbitrage is seen when a stockbroker 
in London, by means of a liberal expenditure on telegrams, is able to buy Canadian Pacific Railway shares on one market and sell them on another : he may operate between London and Paris, or London and New York, or even carry through transactions with all three centres. If the dealing is between this country and America, he buys the shares in Throgmorton Street, London, where they are cheap, and sells them in Wall Street, New York, where they are dear.

When dealing with bills of exchange, that is what happens in some cases, but more frequently the operation may be rather different. When a banker is selling bank paper, the price at which he is willing to sell depends on the price at which he can cover his operation, that is, provide the funds necessary to meet the bills he has drawn. He may do this in several ways, the only consideration being the comparative economy of the method employed. Suppose a London banker has sold three months' bills on his Paris correspondent ; to meet these when the date of maturity comes round, he may cause Dutch bills drawn on Paris to be remitted to his correspondent there; he may even resort to Russian bills for cover, or, as not infrequently happens, send the Paris banker an assortment of paper drawn from various countries on France. It is simply a case of purchasing cover in the cheapest market.

As the effect of arbitrage is to restore the equilibrium of the exchanges, it partakes somewhat of the nature of a levelling operation. It will be apparent that bills can only be bought cheaply in those countries where there are surplus supplies of paper offering, owing to the foreign credits exceeding the foreign debits, and by purchasing the surplus bills not needed by the importers, the operators do much to preserve the normal ebb and flow of the exchange between commercial centres. To take an extreme case, suppose Paris exchange, after being at par, Fcs. $25.22 \frac{1}{2}$, for a few days, goes up by one per mille in 
our favour, i.e., to Fcs. 25.25, Paris can soon offset this small balance in favour of London by remitting bills drawn on London or other European centres.

Dealers in arbitrage have been described as persons spending their time at the telephone with the object of following the movements of exchange on the various markets, and there is an element of truth in the matter, judging by the way they watch the fluctuations in rates and take advantage of every small deviation.

Arbitrage operations in a great measure account for the fact that the exchanges between the chief monetary centres tend to keep on a level. Short exchange on Paris, for example, may move from Fcs. 25.16 to Fcs. 25.30 to $£ 1$, and almost immediately the rate in Paris on London will move in unison. The reason is to be found in the very free use made of the cable. If we quote a better cheque rate than Paris, there will always be exchange dealers on the alert to take prompt advantage of the favourable exchange. With the longer usance paper, however, there is often a suspicion of speculation in the dealings; with cheque rates the outcome is fairly certain, as the following example will show. An operator in exchange, being desirous of making a turn on the rates, and judging the present to be an opportune moment, wires to his Paris friend: "At what rate can you draw cheque $£ 10,000$ on London?" The answer comes back: " 25.20." If the rate in London is favourable, say, Fcs. $25.16=£ 1$, the Londoner wires the reply, "Draw," and immediately the Frenchman draws a cheque for $£ 10,000$ on London and sells it on the Paris Bourse for Fcs. 252,000 (£10,000 at exchange 25.20). At the same time the London operator himself draws a draft on Paris for Fcs. 252,000 and sells it on the market here, or, as is often the case, he has a client wishing to buy demand on Paris Fcs. 252,000. Now the person buying the draft for this amount in London will have to pay sterling calculated at the London rate, Fcs. 25.16=£1, say, $£ 10,015$ 18s.; therefore when the draft for $£ 10,000$ 
arrives from Paris, the London banker has $£ 15$ 18s. over and above the amount required to meet it, and this balance, minus the small charge for stamp and his correspondent's commission, will represent his profit on the transaction.

Similar operations will be carricd out by other dealers, and, other things being equal, the immediate effect of the total drawings will be to equalize the rates between the two countries.

The cases we have quoted are, it should be noted, merely hypothetical, but they correctly describe the principles, and when the operations are extended over two or three centres, it is easy to perceive the influence on the rates of exchange.

Arbitrage is, however, a difficult business, and one which cannot be treated satisfactorily within the range of this book. The student who has mastered the fundamental principles of foreign exchange will be well-advised, therefore, to supplement his reading by reference to one or other of the standard works on the subject. ${ }^{1}$ In view of the importance of this branch of foreign exchange no apology is needed for quoting the following extract from a recent article in the New York Financier : it is a useful summary, and shows that our American friends are fully alive to the importance of arbitrage transactions-

"In conducting such operations it is essential that the banker shall be advised, through the cable, of the varying conditions of the markets abroad. In such markets as Paris and London, where the exchange transactions are always large, rates often fluctuate sharply, and conditions change frequently. Therefore, though the situation may be favourable one day it may suddenly become adverse, neccssitating some modification of the method of arbitraging. Moreover, it frequently happens that after a successful negotiation has been effected

1 Two useful works, in addition to Tate's Cambıst, are : Arbitrages et Parités (O. Haupt) and Bank Notes, Monnaies et Arhitrages (E. Kauffmann). 
by a banker as the result of private information, his competitors may be advised of the favourable conditions prevailing and they also may draw in a similar manner. Hence each operator seeks to obtain for himself alone all possible information regarding changes which are likely to affect his business. Sometimes a banker may find, upon calculation, that it will be profitable to conduct arbitraging of exchange between three or more points; in such cases the conditions at each of the points must first be ascertained and calculations have to be made with the utmost carc. Occasionally in drawing bills the banker, in order to take advantage of arbitraging operations, will transfer credits, through the cable, from an adverse centre to a point favourable for his purpose. Indeed, there are very many ways by which arbitraging can be profitably conducted by bankers having the requisite facilities and the necessary skill for such operations. It will be observed that operations in arbitraging of exchange require the services of men of the largest experience, and hence the business can be conducted to advantage only in the most thoroughly equipped offices. The exchange student who enjoys opportunities for practice in such offices and has the determination to qualify himself for this branch of exchange work by acquiring a knowledge of all of its intricate details will have no difficulty after such qualification in securing advancement. The field for operations in arbitraging of exchange is continually and rapidly broadening, and there will probably always be a demand for the services of men capable of taking positions as managers of exchange houses or departments." 1

Among the banking influences there is one other factor, which is perhaps the most important of all in view of its far-reaching effects on the principal European and

1 Quoted by F. Escher in Canadian edition of Modern Business (vol. viii) : "Banking Practice and Foreign Exchange." 
American exchanges, that is, the bankers' investments in bills.

\section{Bankers' Investments in Bills.}

As far as London banks are concerned, bills of exchange form one of the principal items on the assets side of their Balance Sheets. The bills are an admirable liquid security, and the reason they are in favour with the bankers is, that they may be held in proportions to mature at certain fixed dates convenient for the cash requirements of the banks.

An examination of the contents of a London banker's portfolio would reveal two classes of bills, $(a)$ those arising from the purely internal transactions, $(b)$ those emanating from the foreign trade of the country. The first class is well known to those engaged in the home trade of the country. A merchant may receive from a customer in payment of goods an acceptance at, say, three months' date, and if he and the acceptor be in good repute, the banker will discount the bill for a small charge, place it in the bank's portfolio, and there it will remain until maturity, since it rarely, if ever, happens tlat a British banker re-discounts such paper. The second class embodies those bills drawn from abroad on this country and accepted here by London or other British firms. When completed the bills are sold to the bankers, who hold them in the same way as the other bills.

Now while British bankers in London invest in bills payable in this country, they are generally averse from holding bills payable on other European centres: some even go a step further, and refuse to have anything to do with paper bearing the names of acceptors whose principal place of business is abroad, or the major part of whose assets are not available in Great Britain.

The bills in which the London bankers invest, once they find their way into the bankers' portfolio, can have very little effect on the foreign exchanges, but the case is 
different where foreign bankers are concerned. They, for various reasons, are content to risk funds in the purchase of what are, to them, foreign bills, and at most periods of the year they hold an assortment of bills on all the principal European centres.

Their operations may be divided into two sections, (1) the investment in bills as a means of attracting gold to the country in which the bankers are domiciled, (2) investments in bills for the purpose of obtaining an interest yield higher than can be had if bills on their own country are purchased.

As regards the first class, the reader will readily understand the power conferred on the holder of bills drawn on one or other of the gold centres : assuming the bills to be payable in London, if the bankers of the foreign nation resolve to draw gold from us to replenish their reserves, nothing is more simple than to send the bills to London and sell them on the market in exchange for bank notes. These will be presented to the Bank of England and payment made in gold, which is then packed and shipped to the country that formerly held the bills. As an alternative, the bills may be sent here for encashment at maturity, and funds then withdrawn from London; and, as we have seen, it does not always follow that the rate of exchange is against London when gold is withdrawn from us.

As a matter of fact, the central banks in some countries are specially empowered to invest a proportion of their assets in foreign bills, for the express purpose of manipulating the foreign exchanges. The Austro-Hungarian Bank, to which we shall refer later, may be quoted as an example. The Austrian laws governing this bank's note issues, permits of its holding a part of its assets in foreign bills, which are utilized when occasion requires for the steadying of exchange with London and other centres. When the supply of other remittances is exhausted, it is really this bank which steps in and fills the breach by selling its foreign bills to meet the Austrian demand. 
Just how many foreign bills the Austro-Hungarian Bank held at the outbreak of the war it is impossible to say, but there is no doubt that many thousands of pounds worth were promptly realized. During the war, of course, there was no direct quotation with London, but some idea of the extent to which exchange depreciated was obtainable from figures given in the Economist of 6th March, 1915, when the rate, based on the parity of a neutral country, was given as Kr. 31.33, and comparing this with the Mint Par given on page 22, Kr. 24.02, we see that Austrian exchange was at that time quoted at over 30 per cent. discount. For the time being, therefore, Government control of the foreign exchanges was a negligible factor.

The foreign investment in London bills in order to obtain a high rate of interest is more of a bonâ fide nature. The operations are usually seen when the rate of discount for first-class paper is higher in London than in the foreign centre. Say, the market rate of discount here is 4 per cent., and in Berlin or Paris 3 per cent., bankers on the Continental markets will at once seek to obtain the higher yield on their funds by making purchases of bills on the London market. The foreign banker in this case takes the place of the London banker as a discounter, but in the converse case British bankers show no inclination to occupy the Frenchman's or German's position. It seems to be the golden rule in London to refrain from embarking funds in the purchase of Continental bills, no matter how attractive the rate of return. For instance, if the market quotation here is 2 per cent., and in Paris 3 per cent., the reader may look in vain for British investments in bills on France.

Apart from the higher interest, the chance of making a little extra profit on the exchange is always an attraction for the foreign dealer. Although the bills are said to be for investment, yet, if the banker sees a favourable opportunity, he is quite ready to dispose of them, and in some cases, notably where the rate of interest in London falls before the bill has matured, it may suit him to realize his 
profit by selling the paper at once. It will be apparent to the reader that we are referring to the purchase of three months' bills, or, in the language of the market, long exchange. A concrete case will elucidate this matter.

In Chapter V, we saw how the long and short rates were calculated, and by an application of the rules there given, we can show how the dealer makes his profit.

The cheque rate, Paris on London, in our table was quoted about Fcs. 25.17; consequently, the long rate for bills on London will be, approximately, Fcs. 24.92, since if we are in the foreign centre where currency is quoted in foreign units to the pound sterling, interest at the London rate is deducted from the short quotation (say, 25.17 minus three months' interest at 4 per cent. . . 24.92), showing that less is paid for a three months' bill than for one payable on demand. At this rate a three months' bill for $£ 100$, Paris on London, would cost Fcs. 2,492, and if we assume that during the tenor of the bill there is no alteration in the cheque rate, Paris on London, at maturity the French banker can sell it as a cheque, or sight bill, at the short quotation, say, Fcs. 25.17 to $£ 1$, and thus net twenty-five francs as his profit, or, as we prefer to call it, interest on his original outlay at the rate of 4 per cent. per annum for three months. In comparison with this, French bills held over the same period would show 1 per cent less, as the rate was only 3 per cent. per annum.

There is, however, an element of uncertainty about the quotations, which to the more cautious British bankers, makes the operation savour of speculation. There is just the chance that the cheque rate may alter a point or two, or the rate of interest in London change. For example, when the bill fell due, our Paris friend might find short exchange quoted at Fcs. 25.14, and all the bill would fetch on the market would be Fos. 2,514, which brings his interest down to 3.13 per cent. On the other land, if the short rate goes up before the maturity of the bill, the return increases proportionately. When Continental 
exchanges are low and London interest rates high, there is thus an inducement for the foreigners to invest in our bills. The prospect of higher interest, plus a chance profit on the exchange is obviously an incentive to those bankers willing to take the risk, and long years of dealing have demonstrated that they are fairly safe in buying bills under the conditions indicated. Only in exceptional circumstances will the quotations fall considerably; in ordinary times, in fact, the chances are against rates going below export specie point, and, appreciating this, the bankers rest secure in the hope that a slight rise in the rates may occur, and so enhance their profits.

This, then, is why, when our interest rates are above those ruling in foreign centres, and the exchanges on those countries are low, a heavy investment demand for bills sets in from the Continental banking and finance houses.

The manner in which these operations affect the exchange with London is rather a long story ; therefore, it will be convenient to discuss the subject in the next chapter in connexion with Bank Rate and market rate of discount. 


\section{CHAPTER VIII}

\section{BANK RATE AND MARKET RATE OF DISCOUNT IN \\ CONNEXION WITH THE FLUCTUATIONS IN \\ THE FOREIGN EXCHANGES}

In the last chapter we laid no special emphasis on the fact that in the purchasing of bills on London it is the market rate of discount which is taken into account by the foreign dealers, and one imagines the student's saying, "Why is it that the Bank of England Rate is not of importance?"

\section{Bank Rate.}

The reason is this. In most of these transactions, the foreign banks buy only first-class bills, and if at any time it becomes necessary to turn the bills into cash, they will be discounted on the London market at the lower rate, which is invariably the market rate. Bank Rate, which is the Bank of England's minimum rate for discounting bills, is usually a trifle higher than the market quotation ; not because the Bank declines to discount, since in practice bills will generally be discounted for its clients at about the same rates as can be procured on the open market, but because the Bank of England is the custodian of the nation's principal gold reserve, and its minimum rate is based on the greater or less need there is to protect this reserve from the inroads which may be made into it. We have seen how these encroachments are possible, when foreign bankers sell the bills they have previously purchased on the London market. On the other hand, the joint stock banks, the bill-brokers, and the discount houses, are not at present under the liability to keep large tangible gold reserves; consequently they are able to work on lower rates. Nevertheless, they are all more or less dependent on the Bank of England, and the premier institution is usually in the position to exert its influence when needful. 
How this is done is best seen by examining the effect of an increase in Bank Rate upon the other operators in the market.

In the first place, it should be borne in mind that the Bank of England allows no interest on money deposited with it ; the joint stock banks for their part, allow interest at $1 \frac{1}{2}$ per cent. per annum below Bank Rate, while the bill-brokers, discount houses, and the like, pay a rather higher rate of interest than the joint stock banks.

There are other rates of interest in the money market which bears a direct relation to Bank Rate, but the three we have enumerated are sufficient for our purpose.

As most people are aware, the bill-brokers work on capital borrowed from the joint stock banks, which also lend large sums to the Stock Exchange on similar terms to those governing loans to the bill-brokers and discount houses, namely, at call or short notice. The amount lent out in this way is that obtained by the banks from customers' deposits, and whenever the Bank Rate is raised, the interest allowed by the joint stock banks also rises. If, then, the banks are obliged to pay more interest to their clients who deposit funds for varying periods, it is only natural that they should exact the difference from the dealers to whom they lend their surplus cash. The incidence of this charge will finally be shifted by the brokers on to the persons for whom they discount bills, much in the same way as taxation on commodities is shifted on to the consumer.

In practice the process does not always work out so smoothly, and it is then that the Bank of England resorts to other expedients.

When gold is leaving the country, and further exports of the metal are threatened, it sometimes happens that the market rate of discount does not respond to the increase in the Bank's official minimum: the Bank of England then takes steps to compel the other interests to follow its lead, simply by stopping, or limiting the supplies of 
loanable capital which are available for bill discounters, stockbrokers, and other borrowers on the short loan fund of the London money market. There are various ways of doing this, but in principle they all come to the same thing: that is, the Bank of England by deplenishing the amount of loanable capital on the money market, forces the joint stock banks to call in the loans from the brokers. The market is then said to be in want of money, or, to use a colloquialism, " in the Bank." There will be difficulty in selling bills of exchange, or in borrowing on securities, and as at such periods most financiers consider it advisable to increase their stock of money, they will ${ }^{\circ}$ call in all the loans they conveniently can. The banks for their part, feel it incumbent upon them to hold less securities and more cash, consequently the brokers and discount houses are for the moment at the end of their tether. As all else has failed, they are practically obliged to go to the Bank of England for assistance. The Bank then supplies them with funds by discounting short bills, with not more than fifteen days to run, and by lending them amounts of money for short periods against the deposit of satisfactory security.

In such circumstances, the Bank of England is able to exact suitable rates, and as the borrowers are made to pay a higher price for accommodation, the natural sequence is for the market rate of discount to go up, as the billbrokers are pretty sure to recoup themselves for the additional cost of the funds which they employ in the market. There has recently been an instance of this manipulation of the London money market, without an increase in the Bank Rate. During the second week in March, 1915, the Bank of England's gold reserve, although large, was in danger of having calls made upon it owing to the huge purchases of war material by this country from neutral states, and with the low discount rates ruling there is no donbt gold would soon have left the country in large quantities. Immediate action was therefore taken to effect a scarcity of money here, and so by causing higher 
interest rates, make it more profitable to leave money for employment in London than to draw it away to foreign countries. In the case under discussion the Bank of England and the clearing banks were jointly concerned in the operation of reducing the existing credits on the market. The Bank of England took large sums of money off the market, and the joint stock banks called in their loans to brokers. Then when the bill-brokers required to borrow again, higher rates were exacted for loans at call, and the result was seen in a sharp rise in the value of short money, to which discount rates quickly responded.

The interconnexion of Bank Rate and market rate, now being apparent, it is easy to see how closely the Bank Rate is allied with the question of foreign exchange. The higher the interest rates ruling in London are above those in the foreign centre, the greater will be the investments in bills from Continental bankers, and, what is perhaps more important, the less incentive will there be for foreigners to send long bills to London for discounting. As every foreign purchase of paper means the provision of funds, the outflow of gold will be checked, and the exchanges turned in our favour.

The Continental investment in bills on London may continue for some time, more or less spasmodically, it is true, until exchange rates rise, or until there is an influx of gold into London. Then we see the reverse action: with exchange rising and interest or discount rates low here, the foreign bankers generally realize their holdings of London bills, and almost immediately the exchange drops or the rise is checked, and gold imports cease.

Movements in our Bank Rate are always closely noted abroad, and the following comment, brought to the author's notice after this chapter had been written, is interesting, as showing how thoroughly the Americans are in accord with Goschen's expression of the theory:

"Much is said of the influence on the rate of exchange and on the flow of gold, of the Bank of England 
discount rate. If the Bank of England, because of too rapidly expanding loans or because of depletion of reserves, raises its rate of discount, being followed in this move by the other English banks, its doing so has a tendency to lower the rate of exchange in England on the United States and other countries, and to raise the rate in the United States and elsewhere on England. It has this effect because the increased interest in England tempts to investment there rather than in the United States. English banks are more likely to invest current funds at home, and may even draw on debtor banks in the United States and other countries. American and other banks may be tempted to make short term loans in England or to hold, or to have held until maturity, long bills which they would otherwise have immediately discounted. This holding of drafts until maturity will compel them to buy more drafts on England than otherwise would be necessary, in order to maintain their usual balances. The general result of a high discount rate in England is, therefore, a high rate of exchange on and a flow of gold to England. Similarly, a sharp rise in the discount rate in New York would tend to produce elsewhere a high rate of exchange on New York, and would tend to cause a flow of gold to New York." 1

From a consideration of these facts, we are able to appreciate the intimate connexion a change in the Bank Rate has with the movements of foreign exchange: the effect of raising the Rate, and the subsequent manipulation of the money market, is to create an artificial scarcity of money and at the same time cause a depreciation in the value of bills of exchange on the London market. A fall in the price of bills attracts investors from abroad, and as the result of their purchases of paper, an adverse exchange is turned into a favourable one-using the word in its

1 International Trade and Exchange, H. G. Brown (New York), page 134. 
widest sense. Indeed, the ultimate outcome of dealings of any magnitude, is to draw gold from the foreign centres to London, and without entering into the question whether or not the accumulation of huge gold reserves is the fetish that some cavillers claim it to be, we have always before our eyes the indisputable fact that when the Central Reserve is adequate the monetary position of the country is more satisfactory.

We need not go further into the question here, but sufficient has been said to enable the reader to understand that, other things being equal, the adjustment of interest rates in practice aids and abets, or rather brings into being the compensatory influence of the investment business in bills of exchange, a business which is so well known to those who watch the monetary movements, that its action has come to be regarded as a sort of pendulum of the foreign exchanges: it steadies the fluctuations and exercises a most powerful effect on the import and export of gold.

Apart from the benefits said to accrue from the manipulation of the Bank Rate of discount as a corrective to an unfavourable exchange, the economic effects of a too frequent alteration in rates has sometimes been called in question, and, although the subject is hardly one which concerns the student of foreign exchange, brief mention ought perhaps to be made of the view taken.

Summarized, the opinions expressed amount to this, that if gold reserves must be maintained, then other steps should be taken to protect them. In this connexion we might refer to the French policy. The Bank of France, can, if thought desirable, adopt the expedient of exercising the right which is conferred upon it and all debtors in countries in the Latin Union, to make payment in silver in five-franc pieces, instead of paying out gold on demand.

Whatever be the merits or demerits of the respective systems, it has been proved that the French bank rate tends to remain very steady at 3 per cent., and in this 
BANK RATE AND MARKET RATE OF DISCOUNT, ETC. 91

respect compares favourably with other European rates. For instance, the Bank of France's rate from 1876 to 1909, with thirty alterations, averaged 3.13 per cent. ; over the same period, the Reichsbank changed its rate 125 times, giving an average of 4.11 per cent. ; while the Bank of England's rate was changed 200 times, which gives an average of 3.28 per cent.; from which it follows that French commerce benefited to the extent of 0.98 per cent. over German industry, and $0 \cdot 15$ per cent. over British industry. ${ }^{1}$

1 Cf. the Author's review in the Economic Journal for December, 1913, of "Huart's Organisation du Credit en France." 


\section{CHAPTER IX}

\section{THE MONEY MARKETS OF THE WORLD AND THE}

GREAT WAR

"WAR is hell," wrote one of the active service men, face to face with the awful devastation wrought by the Germans in their advance through Belgium. The expression is a strong one, but applies with equal force to the financial havoc brought about by the war, and in no direction is the ruin, the disgrace, the woe of war more faithfully reflected than in the world's money markets and the foreign exchanges. So delicate, in fact, is the mechanism of the money markets, and so close is the relationship between them and the foreign exchanges, that the latter may always be taken as a trustworthy index to the monetary condition of the various markets. It will be interesting, therefore, if we now examine some of the effects of the war in the light of the monetary problems with which we have been dealing, and endeavour to see how far the results confirm the theories we have enunciated.

One of the first signs of the imminence of a war between two nations having intimate commercial relations, is the speed with which the merchants and financiers of the respective countries try to realize their opposing claims. There is an eagerness to collect foreign debts, and to dispose of all tangible securities in exchange for gold, and the more strained the tension between the two countries becomes, the more pronounced will be the desire to convert foreign claims into cash-at a greater or less sacrifice. This liquidation of claims will grow in intensity until diplomatic relations are broken off between the respective nations: it will not even cease at that point, for immediately war is declared and hostilities commence, the claims of the belligerent nations will be dumped upon neutral markets 
for realization, until all are surfeited with the many and varied forms which foreign indebtedness takes. At this stage, having reached the limit of their receptive powers, the neutrals become involved in the financial strain which at first merely affected the countries which are at war.

\section{Gold Movements.}

The great European conflict, as it happened, came at an awkward moment for all the Continental centres. A certain amount of depression had been evident as far back as 1913, and even at that period the financial condition of the world's markets was far from satisfactory. Continental markets were in general overloaded with securities, and a great many more issues had been floated on the London market than the British investors were able comfortably to absorb. During the early part of 1914 , however, a turn for the better took place; gold flowed into Paris from New York as the result of French realization of securities, and the Bank of England, for its part, was able to procure a sufficiency of the precious metal. Money rates dropped correspondingly and ease prevailed in most centres for some time. But, towards the end of May, the tide began to turn, the Bank of England's reserve fell to a lower level than was liked, and at the same time a great demand for gold sprang up from the Continent. French exchange was against England during the whole of May, while that of Berlin was favourable to London, yet, according to The Times' Financial Review of the year, out of the gold arrivals in London amounting to nearly $£ 26,000,000$ sterling, the Bank of England secured less than $£ 7,000,000$. The amount sent to France and Germany was about equal to the exports to the Continent for the whole of 1913, and although it was reported that Russia was the ultimate destination of a portion of these Continental purchases, there is no doubt that the greater part found its resting-place in the vaults of the Central Banks of France and Germany. 
The influence of these gold shipments was soon reflected in the exchanges. The quotation, Berlin / London, moved

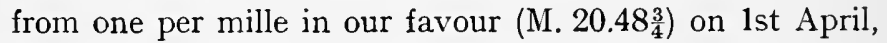
1914 , to $3 \frac{3}{4}$ per mille in our favour (M. 20.493) on 30th May; on 23rd May, it might be remarked, the quotation was M. $20.50 \frac{1}{2}$, very near the rate at which the Bank of England should gain gold at the expense of the Reichsbank, namely, M. 20.53 .

French exchange, examined over the same period, showed several variations, but towards the end of May was only slightly against this country.

American rates were persistently in our favour the whole time, and as we have stated elsewhere (page 36), at one period New York's excess imports were being paid for by gold, the adverse exchange being due, partly to the failure of the main crop, and partly to the fact that speculation was then at a very low ebb in the United States. ${ }^{1}$ There is little doubt that the European demand for gold was making itself felt in the United States, for it has to be recorded that during the first half of the year 1914, the Continental demand for gold was greater than during any one of the three preceding years, and the intensity of the demand for the metal, coming at the same time as other adverse circumstances in the United States, caused rates on the three principal European centres to go against New York. Exchanges generally were against America, and the rate, New York-London, on or about 13th June was quoted $\$ 4.89 \frac{1}{2}$ to $£ 1$, that is six per mille in our favour. ${ }^{2}$

Despite this almost unprecedented ingathering of gold by the Continental nations, there does not appear to have been any actual uneasiness until the turn of the half-year. Then the Austro-Servian imbroglio began to take definite shape, and the influence of the strained relations between the two countries was immediately seen on the London market by the hardening of discount rates.

1 Cf. Economist, 6th June, 1914.

3 It is interesting to note that New York-London Exchange was buoted by the Economist at par, \$4.863, on 4th April, 1914. 
Then, on the 18th July, the news leaked out that the Dresdner Bank was selling its securities and advising its clients to act similarly. This, as Sir Edward Holden remarked, ${ }^{1}$ was considered to be the first semi-official intimation of a probable European conflict.

The climax was reached on 28th July, when the fear of war gave place to certainty, and discount quotations at once jumped to 4 per cent. for three months' bills.

The foreign exchanges all along had indicated the drain of funds, and the real gravity of affairs on the Continent was shown by the rates current on the 28th July. Paris cheque, for instance, was quoted 25 f.11-12 c., Brussels, 25 f. $28-30$; Berlin sight, 20 m. 53-55 pf. ; Vienna, sight,

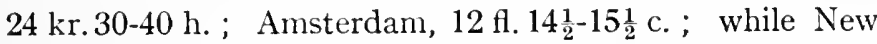
York wired "Cable Transfers, $\$ 4.90-4.93$ c."

Before going further, we may be permitted to make a digression and refer briefly to the situation in which the principal money markets found themselves on the outbreak of hostilities.

\section{Condition of Money Markets.}

Paris, it is evident, was caught between Scylla and Charybdis : she was embarrassed by her holdings of shortdated securities as the outcome of operations financed for Turkey and the Balkan States, and before she could rid herself of this incubus, she was caught by the serious effects of the monetary crisis which had spread to all classes of society in France. Gold disappeared as if by magic, and heavy calls were made on all the banks in France for cash. To stem the tide, on the 31st July, the Bank of France raised its rate from $3 \frac{1}{2}$ per cent. to $4_{2}^{1}$ per cent., and its rate of interest on advances from $4 \frac{1}{2}$ per cent. to $5 \frac{1}{2}$ per cent.

Berlin evidently anticipated the worst : there was great pressure everywhere for gold, the banks were literally

1 In his speech to the shareholders of the London City and Midland Bank, 29th January, 1915. 
besieged, and what may be termed as " a great run" took place on the Reichsbank, which is said to have parted with gold to the value of Mks. 200,000,000. The exact figures are not forthcoming, but tantamount to admitting that the withdrawal of gold had been on a gigantic scale, is the fact that a measure was soon passed, prohibiting the Bank from paying any more of its gold for notes. On 31 st July the Reichsbank was forced to raise its rate of discount from 4 per cent. to 5 per cent., and its rate of interest on advances from 5 per cent. to 6 per cent.

How far foreign exchanges went against Germany may be gauged from the remarks of the Economist's Berlin correspondent, on 30th July, 1914. "London and Paris cheque rates," he says, " have risen to an almost unprecedented height, and gold could now be exported with profit to both England and France. Movements of exchange are attributed partly to the fact that England and France are withdrawing their balances from Germany, Austria and Russia, while the capitalists of these latter countries are sending money abroad, especially to England, in considerable amounts."

As far as the Berlin Bourse was concerned, it is interesting to recall that, by order of the President, from 31 st July no prices were fixed on the bourse, and although it was announced that "transactions were confined to cash basis," there was no business at all in securities.

Of our own position it is necessary to speak more fully. It goes without saying that London early became involved in the great financial cataclasm. Immediately after the outbreak of war between Austria and Servia, discount rates were quite nominal, ${ }^{\mathbf{1}}$ and owing to the great difficulty in placing bills, the market was temporarily paralysed for want of funds. Dealers on the open market were all the more crippled by the banks calling in their loans, and as a result, the bill-brokers were forced to seek accommodation

1 Rates on 29 th July were: Bank bills, 3, 4, and $6 \mathrm{~m} / \mathrm{s} .496 \%$; fine trade bills, $3 \mathrm{~m} / \mathrm{s} .5 \%, 4 \mathrm{~m} / \mathrm{s} .5 \frac{1}{6} \%, 6 \mathrm{~m} / \mathrm{s}$. $5 \frac{1}{2} \%$. 
by borrowing from the Bank of England and selling to it "short" bills. This was on 29th July. By the 30th July the London Stock Exchange was in the toils, finding itself unable to absorb the large quantities of securities which had been forced on the market from all quarters, and the severity of the strain led to the closing of the Exchange on the following morning, until further notice.

The drain on the Bank of England's stock of gold has already been referred to, and on 31st July, it became necessary to take precautionary measures by raising the official rate from 3 per cent. to 4 per cent. The demand on the joint stock banks, however, continued unabated, and in consequence, loans were called up in all directions, which simply meant that the discount brokers were again obliged to go to the Bank of England for assistance. At the outset the Bank discounted their short bills at 6 per cent., but as the day went on, the pressure increased, and in proportion to the borrowings the Bank raised its charges, until 10 per cent. was charged for discounting bills with about fifteen days to run. On loans for a week, the rate was still higher, as much as $10 \frac{1}{2}$ per cent. being charged and paid. The rot had set in, and to check it drastic measures obviously were necessary, therefore the Bank took the unusual step of altering its Rate on a Friday, advancing it to 8 per cent. London borrowings were not the only reason for this action; it was quite as much due to the heavy withdrawals of gold from the Bank for toreign account, for during the day (31st July), no less than $£ 1,204,000$ was taken for shipment to the Continent.

As The Times remarked on the following day, 8 per cent. is by no means an unexampled rate in the history of the Bank of England, and the table, given by that paper, is interesting as recording the dates on which 8 per cent. or more was fixed by the Court of Directors. 


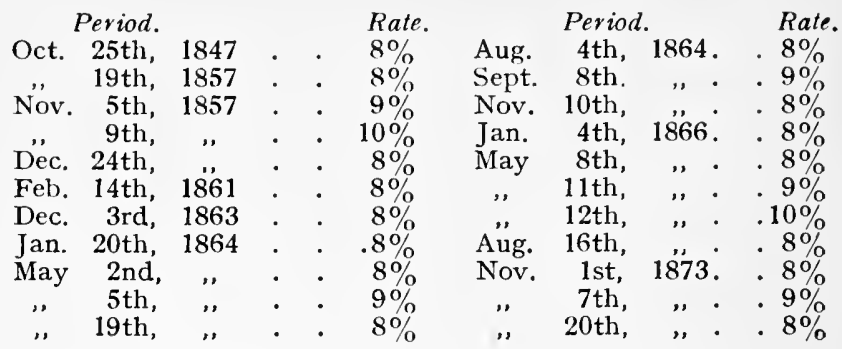

Bank Rate, during 1914, was at 3 per cent. from 29th January to 29 th July, it was raised to 4 per cent. on 30th July, to 8 per cent. on 31 st July, 10 per cent. on 7th August, and reduced to 5 per cent. on 8th August, at which rate it has stood up to the time of writing.

Not taking into account Sunday, 2nd August, and the Bank Holidays from 3rd to 6th August, we may say the actual crisis lasted four days only. We use the word crisis advisedly, in preference, in fact, to the much stronger term " panic," which is held by some people correctly to describe the situation.

\section{Government Action.}

The consensus of opinion, outside banking circles, seems to be, that the action by the banks in calling up all their loans from the discount brokers and other similar borrowers, to some extent precipitated the crisis, inasmuch as that course of action enhanced the already heavy demands on the Bank of England for accommodation. The London banks, however, were not alone in their ultra-cautious policy. Practically the whole Continent, from Paris to Petrograd, and from Amsterdam to Vienna and Rome, was seeking to convert paper into cash, added to which the great banks in Paris and Berlin were hoarding gold against emergencies. ${ }^{1}$ Fortunately, the prompt measures taken by the Government in consultation with the Bank of England authorities, were effectual in staying the timidity with which a large section of the community had begun

1 Cf. Economist, 1st August, 1914. 
to view the abnormal financial situation : that cven stronger measures would have been taken had circumstances called for them, is evident by the frank way in which the Press were allowed to announce, on 1st August, 1914, that proposals were under consideration for obtaining the Government's assent to the suspension of the Bank Charter Act, of 1844, the effect of which would have been to enable the Bank of England, if necessary, to issue notes without holding gold against them. To paraphrase the leading article of The Times of 1st August, in the opinion of the Government that course was not then actually necessary, but the Chancellor of the Exchequer was understood to be ready to give the Bank authority to act, merely by the issue of an official letter from the Treasury, and the announcement that should the situation require, he would issue the necessary letter, no doubt went far to restore the confidence of the City and all connected with it.

Of the American money market we need say little at this stage. With the outbreak of war the other centres turned their attention to the New York Stock Exchange for the realization of their securities. The increased business was too much, even for American ideas; within a few hours the extensive liquidation completely demoralized the market, and, after holding up bravely as the world's dumping ground for the sale of stocks and shares, the Exchange bowed to the inevitable and closed its doors on 31st July, until further notice.

In the New York money market proper, the position, although not " panicky," was uncomfortable: call money was unobtainable- " no quotation," the papers announced ; international exchange operations were at an end, and the discount market was in a state of paralysis.

Having briefly considered the effect of war on the principal monetary centres, we may pursue the matter a step further, and examine the manner in which the foreign exchanges fluctuated owing to the economic pressure on the world's markets, commercial as well as financial. 


\section{CHAPTER $\mathrm{X}$}

THE FOREIGN EXCHANGES AND THE GREAT WAR

WHEN we realize that for a period following the outbreak of war the credit system of the principal markets of the world had broken down, it is not surprising to find that the foreign exchanges went literally to pieces, too. Their condition from the end of July to the second or third week in August, 1914, almost beggars description. The state of the money markets was chaotic, that of the principal foreign exchanges-if there be degrees of chaos-even more so, and the complete disorganization of the exchanges did much to intensify the shock which the credit of practically every country in the world had sustained in the early days of August.

The following table drawn up by the Economist in December, 1914, gives the position in a convenient form. We have added a column giving the actual rates in operation at the time this chapter was written, March, 1915.

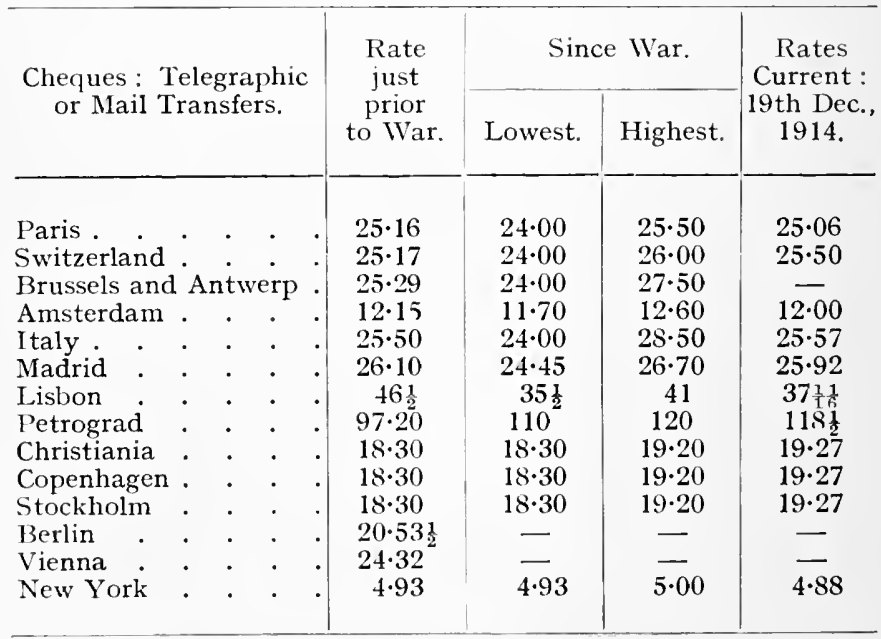




\begin{tabular}{|c|c|c|c|c|}
\hline & & & $\begin{array}{c}\text { Extremes quoted } \\
\text { about } \\
\text { 1st August, } 1914 \text {. }\end{array}$ & $\begin{array}{c}\text { Rates } \\
\text { quoted } \\
\text { 19th Mar., } \\
1915 .\end{array}$ \\
\hline Paris & . & & $24 \cdot 00-25 \cdot 00$ & $25 \cdot 25-25 \cdot 45$ \\
\hline Switzerland & $. \quad . \quad$. & . & Nominal & $25 \cdot 92-26 \cdot 15$ \\
\hline Brussels and & Antwerp & . & $24 \cdot 00-26 \cdot 00$ & - \\
\hline Amsterdam & $. \quad . \quad$. & . & $11 \cdot 90-12 \cdot 60$ & $12 \cdot 08-12 \cdot 13$ \\
\hline Italy. . & . & & $26 \cdot 00$ sellers, no buyers & $27 \cdot 80-28 \cdot 10$ \\
\hline Madrid & . & & $24 \cdot 00-25 \cdot 90$ & $24 \cdot 30-24 \cdot 45$ \\
\hline Lisbon . & . & . & 42 & $344^{3}-35$ \\
\hline Petrograd & . & & 125 sellers, no buyers & $113-115$ \\
\hline Christiania & . & . & about $18 \cdot 50$ & $19 \cdot 25-19 \cdot 45$ \\
\hline Copenhagen & . & . & " $\quad$, & 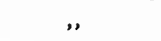 \\
\hline Stockholm & . & . & & ," \\
\hline Berlin . & . & . & 21.00 sellers, no buyers & - \\
\hline Vienna . & . . . & . & $24 \cdot 60 \quad$," & 一 \\
\hline New York & . . . & . & about 6.50 & $4 \cdot 79_{4}^{3}-4 \cdot 80_{\frac{3}{4}}^{3}$ \\
\hline
\end{tabular}

The rates shown in this table testify to the severity of the breakdown, and the universal way in which the foreign exchanges collapsed was one of the worst features of the problem with which the bankers and financiers have had to deal.

At the commencement the stagnation in rates was to a very great extent the result of the wild movements in quotations for the various forms of capital, reference to which was made in the last chapter: the enormous monetary claims which had been in process of liquidation left exchange markets in a debilitated condition, and when markets did begin to recover, operations were insufficient to put the financial machinery in motion again. Let the reader just imagine the position. Business, speculation and investment all over the world were in a state of inanition: not only were the principal stock exchanges and bourses closed sine die, but the majority of the commercial exchanges were in a like position. In Great Britain it became necessary to cease dealings on the London Metal Exchange, the Coffee Market at Mincing Lane, and the Seed and Oil markets on the Baltic Exchange, and most of 
the wheat and grain centres were similarly affected. There is no need to multiply instances, but an examination reveals the fact that markets throughout the entire world were in no better state.

Such events demonstrate in a striking degree the close relationship between money and the exchanges: they show that the different forms of money in one part of the world are affected by occurrences on other markets, and the fact that there ensues a stoppage of trade and speculation in commodities such as grain, coffee, meal, oil, cotton, etc., may be taken as proof positive that the world's credit facilities are part and parcel of one great fabric-any weakening or dislocation at one point must, in consequence, react on other parts of the machinery. In such circumstances, London, as the greatest exchange centre in the world, is the first to feel the effects, and the more exchange facilities are restricted in London, the greater will be the loss in other centres, for, as Mr. Lloyd George cogently remarked, in the absence of exchange facilities, goods can neither be imported nor exported in any appreciable quantity. ${ }^{1}$

Apart from the interruption of communication between certain countries, and the subsequent cessation of arbitrage business with the chief centres, it is a matter of some difficulty to place the finger on the exact cause of the movements in rates; all we can do is to examine the exchanges of the more important countries and endeavour to trace the reasons for the rise and fall, as the case may be.

1 In its issue of 12th September, 1914, the Economist rather dissents from this view, preferring to take the state of the exchanges and the difficulties of the bill market more as a symptom than a cause. "The bill market cannot make trade which does not exist," Isays the editor, " and the absence of bills merely testifies to the absence of trade."

In some cases, this was no doubt true: but many instances came under the author's notice during the first few weeks of the war, when bills were offering in fair quantities, but exchange banks and dealers refused to take them, owing to the uncertainty of their being able to procure return remittances from the countries for which shipments were destined. 


\section{Effect on Foreign Exchanges.}

FrANCE. Reference to our table will show that just before the war Paris cheque was quoted at $25 \mathrm{f}$. $16 \mathrm{c}$. to $f 1$, but immediately the fear of war became definite, France proceeded to replenish her exchequer by realizing securities, clearing out portfolios of London bills, and calling in all balances held in this country. As a result, remittances in London on Paris were rapidly exhausted, and when the scarcity became pronounced, those who were under the obligation to remit, bought gold to send to France. These, very briefly expressed, are the reasons for the fall to $24 \mathrm{f}$. to $£ 1$.

In New York, the quotation on Paris was even worse than the London rate, dealers being willing to give only Fcs. 3.25c. to the dollar.

Germany. German exchange, from the commencement of the war to the end of the year 1914, is a complex subject to enlarge upon, and most people have preferred to study the course of the exchange with that country from data obtainable in New York. From the various rates cabled by The Times and other correspondents, it is possible to get some idea of the movements.

The par of exchange, New York/Berlin, is approximately $95 \frac{1}{4}$ cents to 4 marks, and as we have already explained, New York quotes Berlin exchange in cents to 4 marks. At the end of August the rate was $96 \frac{1}{2}$, by the end of September it had depreciated to $94 \frac{7}{8}$, and continued to fall rapidly for the next two months. The Royal Statistical Society's correspondent gives the quotation at the end of November as 853 cents, or 9.7 per cent. discount on the gold parity. In the early days of December, there was rather a remarkable recovery, the rate being quoted on 8 th December at $92 \frac{1}{2}$ cents to 4 marks, but, as the same authority indicates, the upward movement did not last long, and towards the end of the year The Times' quotations on an average represented a discount of about $7 \frac{1}{2}$ per cent. 
It is said that earlier in the ycar 1914, the German financiers had sold a considerable part of their American investments, and the fund created by these sales is estimated to have provided a certain amount of credit against which drafts could be drawn. Certainly, the recovery in Berlin exchange in New York early in December may be attributable to credits raised by the realization of securities on the New York market, since, " the restraints on German trade hindered the export of goods in quantities sufficient to provide the means of payment for desired supplies." 1

By way of a further corrective to its unfavourable exchange with Continental countries, Germany sent gold to Holland and other Scandinavian countries, but the improvement in every direction was merely temporary; exchange soon fell to its former low level, and at the time of writing (March, 1915), the quotation, worked through Holland, indicated that German exchange with London had depreciated to about 12 per cent.

There is a tendency in some quarters to discredit the statement that Germany was compelled to part with gold in order to pay for imports from Holland and Scandinavia, but facts which have come to light go to prove that she certainly did export gold. Of the war indemnity exacted from France in 1872, $£ 6,000,000$ was allocated for the special war chest to be kept in the Julius Tower at Spandau. This reserve was known to consist of a large proportion of British sovereigns, and during the first week in March, 1915, a considerable number of these coins found their way back to London via Scandinavia. The sovereigns were those bearing the Victoria effigy and the "Shield" reverse, of which a large number was minted during the years 1838 to $1874 .^{2}$ Consequently, when the bankers in London, to whom the gold from Scandinavia

1 Joumal of the Royal Statistical Society, January, 1915.

2 From 1838-70, 128,208,324 " shield " sovereigns were minted ; from 1871-74, "shield" and "dragon" designs were used concurrently. 
was consigned, found it to consist of many new sovereigns bearing the date 1872 , it was at once apparent whence the shipment had originated. Further evidence of their having been taken from Germany's war chest was found in the fact that some of the coins were actually received in the identical bags and boxes in which they had been packed when leaving the Bank of England forty-three years previously, and no little surprise was evidenced in banking circles when it became known that no effort had been made to conceal the place of origin by removal of the old Bank of England labels.

The heavy increases registered in the gold reserve of the Netherlands' Bank from time to time during the war, may also be taken as indisputable evidence that Germany was forced to export gold to Holland in support of exchange and to pay for supplies.

In the month of March, 1915, the direct rate, New York on Berlin, steadily depreciated: the quotation on 1st March was $82 \frac{1}{8}$; on 18th March, 84; 19th March, 83; and on 20th March, 4 marks were worth only $82 \frac{7}{8}$ cents. On the last quotation, therefore, German exchange with New York showed a depreciation of 13 per cent.--a percentage which made foreign imports very dear for Germany, or, conversely, depreciated the value of her exports, if any were possible via neutral countries.

Spain. The other European rates all present features of interest, the fluctuations in most cases being directly traceable to increased foreign trade due to the war. Spain, for instance, derived considerable benefit from the commerce which was diverted to that country from France; in fact, during the early days of the war the Spanish exchange achieved a record, being equal at one time to about 487 d. to 5 pesetas, as against the normal quotation of slightly over $45 \mathrm{~d}$.

Holland. The par of Exchange, Amsterdam/London, is Fl. 12.107 to $£ 1$, the extremes reached on the outbreak of war, Fl. 11.90 to Fl. 12.60, and the quotation, 19th 
March, 1915, Fl. 12.08-12.13c., from which it may be gathered that, although the fluctuations were fairly wide, the rate on London was, generally speaking, well maintained. The quotations with Holland were, of course, affected by the exports, and a decline of nearly one florin from the high rate quoted at the commencement of the war, recorded by the Economist in October, was obviously due to the greatly enhanced exports. The fall, however, was only temporary, and rates soon recovered.

ITALY. Italian exchange fluctuated widely for a time, and was quoted at the beginning of August, 1914, Lire 26 to $£ 1$, on the gold parity of L. $25.22 \frac{1}{2}=£ 1$, approximately 3 per cent. against Italy. This was in part due to large imports of coal, payment for which was rendered extremely difficult owing to the existing financial strain. On 19th December the rate had improved to L. 25.57, but by 19th March, 1915, it was given in the foreign exchange quotations as L. 27.80 to L. 28.10 , a quotation considerably in favour of England.

Russia. Reference to the foreign exchange table given on page 40 will show that the Russian sight exchange on London was quoted on 17th July, 1914, Rbl. 95.75 to $£ 10$, and the extent of the depreciation of the rouble may be gauged from the quotation on 1st August, 1914-Rbls. 125, which indicates that the rouble had depreciated about 32 per cent., taking the gold par as 94.58 to $£ 10$.

The reason for this heavy fall in the value of the rouble, in the first instance was presumed to be due to the large purchases of gold which Russia had made just prior to the outbreak of war, payment for which exhausted all available sterling remittances. Some improvement in values was apparent by the middle of September, when the quotatiun was $107 \frac{1}{2}$, but by the beginning of October, viewed from the Russian standpoint, the rate fell again to 120 ; nearly 27 per cent. depreciation in Russian currency. By the end of the year 1914, the rouble was quoted 
117 to $£ 10$ sterling, and, as we see by our list, on 19 th March, 1915, the Petrograd quotation came through as 113-115.

In common with other countries, Russian exchange is dependent to a great extent on her foreign trade, and at the time of writing she is doubly handicapped. Her exports of grain, provisions, sundry raw materials, and semi-manufactured products of Russian agriculture, etc., have been restricted by the closing of the Dardanelles, and the cessation of trade with Germany and other countries via the Baltic ports and the railways over the west frontier. The closing of the Dardanelles was bad enough, since that definitely precluded Russia from exporting from the ports on the Black Sea and the Sea of Azov, but when a considerable portion of her exports and imports ceased through the suspension of navigation in the Baltic, matters became serious. Then, there is another not unimportant factor to be remembered. Many of the ordinary commodities she habitually exports are consumed by the enormous army she is obliged to maintain in the field. The upkeep of this army, in fact, also entails the importation of a vast amount of produce and commodities from other foreign centres.

Summarized, the difficulty in principle amounts to this : imports in Russia's case could not be paid for by exports, and the importers consequently were unable to procure the drafts by means of which, as we have shown, foreign indebtedness is liquidated. The trouble was all the more acute because many importers had purchased commodities from abroad, which they were perfectly willing and able to pay for, but short of sending gold, no method of remittance was available, for no exporters' drafts were to be purchased. But here, again, the would-be remitter was estopped; he could not send gold, because for the time being, under the law of 10th August, 1914, the exchange of bank notes for gold was suspended in order to protect the gold reserves of the State Bank of Russia. 
The adverse position, as Professor Migulin ${ }^{1}$ rightly pointed out, was due entirely to the fact that with the cessation of Russian export trade, the demand for Russian currency had been sharply curtailed, while, as the outcome of Russia's need for an entire series of foreign commodities, the demand for foreign currency had increased. As the result of all this, Great Britain's trade with Russia had almost ceased, for with such a high level of exchange, it was practically impossible for traders in Russia to remit to London except at ruinous rates.

How, then, was the problem to be solved?

The first expedient Russia hit upon for assisting the exchange position, was the very natural one of shipping gold, of which $£ 8,000,000$ worth was sent to England in November, 1914. In order still further to ameliorate the adverse exchange, the British Government provided Russia with an additional credit of $£ 12,000,000$, proceeds of an issue of Treasury bills on the London market. The provision of this credit rehabilitated the exchange in a limited degree-the depreciation dropped to 14 per cent.but as the credit was largely used for financing the Russian Government's own expenditure on war materials, the increase in the credit did not assist much in restoring the normal exchange, and the problem consequently remained a serious one for the commercial community. Further provision therefore became necessary, and as a result of the historic conference between the allied Finance Ministers in Paris, the amount to be raised in Treasury bills on the London market was increased by $£ 20,000,000$ to $£ 32,000,000,{ }^{2}$ and the effect of this was to bring down the exchange to the more workable figure of Rbl. 113 to $£ 10$

1 The Times Russian supplement, 15th January, 1915.

2 'The arrangement was announced in the following terms on 4th December, 1914-

“ His Majesty's Government agreed with the Russian Government, in consideration of the shipment of $£ 8,000,000$ in gold from Russia to London, which took place a few weeks ago, to arrange with the Bank of England to discount, under a guarantee of His Majesty's Government, Russian Treasury Bills to the further 
The interest this operation created in circles outside the sphere of banking is shown by the comments which the Spectator made on the occasion of the issue of the Treasury bills, and as the analogy drawn in that time-honoured periodical is a very excellent one, it is worth while quoting.

"To understand how the difficulty is to be met," says the writer, "it is only necessary to realize that, though international commerce is primarily a matter of the exchange of goods against goods, it is secondarily a matter of the exchange of goods against permanent securities. If, for example, the Argentine railways want a fresh supply of rolling stock from Great Britain, they can obtain it by issuing new capital which will be taken up by British investors, whose money will go to pay for the rolling stock, and who in return will acquire a permanent lien upon the profits of the railway. Exactly the same method is being employed to meet the temporary commercial difficulties of Russia. The Russian Government are now raising money upon the London market by means of Treasury bills. The money thus raised is used to pay for produce that Russia requires to buy, and the investors in Treasury bills acquire a permanent claim upon the Russian Government. Simultaneously, the Russian Government

amount of $£ 12,000,000$, the rate of discount to be on the basis of the rate at which the British Government has been from time to time able to borrow for its own needs.

"By these means, the Russian Government obtains funds in England to the total amount of $£ 20,000,000$. Out of these, $£ \&, 000,000$ is to be applied by the Russian Government for the purpose of providing exchange for Anglo-Russian trade. This exchange will be available for new transactions, as well as for the discharge of existing indebtedness.

"The balance of $£ 12,000,000$ is to be used for paying the coupons of the Russian external debt and the interest upon other external obligations of the Russian Government which are payable in London, and for financing Russian Government purchases in the United Kingdom. It will not be applied to financing purchases outside the United Kingdom, except after consultation with His Majesty's Government, in cases where the British market is unable to supply the article required, and orders have consequently to be placed in the United States or Canada." 
are collecting from merchants in Russia, money owed to England, and giving in exchange Russian Treasury bills, which are handed over to the persons in England to whom the Russians owe the money. By this means the Russian Government are able both to assist their subjects to pay debts in London and to acquire the cash for carrying on the war."

The whole procedure is a striking instance of the manner in which Continental nations hold tight to their gold when the odds are overwhelmingly against them, and it seems to be a moot question whether Russia would not have done better to meet her foreign indebtedness by the release of gold, of which metal she is reputed to have immense stores. ${ }^{1}$

AmERICA. The position in regard to American exchange was analogous with that of Russia. Following the outbreak of war, American exchange, like that of Russia, became utterly disorganized, and the extent to which the dollar depreciated was even more pronounced than the depreciation of the rouble. There were two chief causes for this disorganization in the United States currency: (a) the abnormal liquidation of stocks and shares on the New York Stock Exchange, which commenced in July, 1914, and grew in intensity until the commencement of hostilities; $(b)$ the almost unprecedented indebtedness of America to Europe, estimated at about $\$ 250,000,000$ $(£ 50,000,000$, taking $\$ 5$ to $£ 1)$. In such circumstances foreign exchange was reported to have disappeared, which is true, theoretically, since quotations were unworkable.

A few words, taken from The Times' correspondent's dispatch, summarize the position. Sight exchange on London, normally $\$ 4.86$, seldom higher than $\$ 4.89$, rose to $\$ 5.00$, to $\$ 6.00$, and, finally, to $\$ 7.00$ - a rate never before witnessed.

In the ordinary course of things, New York could have

1 On 21st July, 1914, the Imperial Bank of Russia held gold to the value of $t 174,509,000$. 
corrected this abnormal position by shipments of produce, following her usual autumnal procedure, when she exports enormous quantities of cotton, grain, meat, and other food-stuffs to Great Britain and other European countries, and takes back gold for any excess balance due. As she was estopped from making these shipments on the outbreak of war, however, the usual means of cancelling her indebtedness to foreign countries was denied her, and the results were disastrous in the extreme.

Gold had been leaving the States in large quantities, and more would have been shipped but for the suddenness of the crisis. It will be within the reader's recollection that the Kronprinzessin Cecilie had sailed from New York on 28th July, 1914, with a consignment of gold to European banking houses, valued at about $£ 2,000,000$, but to avoid capture, she put back into the Bar Harbour, Maine, U.S.A., on the 4th August.

In war time New York might conceivably consider it inexpedient, or even undesirable to ship gold; she would prefer to send cotton, wheat, etc., in payment of indebtedness, but with that means of settlement cut off, and pari passu, the bills of exchange, one's thoughts naturally turn to gold. Here, again, adverse factors crept into the calculation. In normal times it is safe to estimate the cost of shipping gold to London from New York in large quantities at about $\$ 2$ per $£ 100$; the par of exchange, New York/London, given in our table on page 22, is $\$ 4 \cdot 8665=£ 1$, or $\$ 486.65=£ 100 ;$ par, plus the cost of shipping gold would be $\$ 488.66$, and whenever the exchange goes higher-say $\$ 489.00$, gold shipments will commence. In the early days of the Great War, however, there arose exceptional circumstances, largely a matter of history now, but which were similar to those cases which economists have constantly referred to in alluding to the theoretical gold points. We have in mind the special circumstances which cause shipping charges for gold to exceed the amount prescribed in calculating the gold points. 
In the case of the European war insurance rates from New York to London rose as high as 1 per cent. on 30th and 31st July, 1914. ${ }^{1}$ One per cent. increases shipping charges by approximately $\$ 5$ per $£ 100$, making the outgoing gold point \$491.65, and accounts to some extent for the unparalleled exchange which existed.

In view of this remarkable situation, foreign exchange, if not at an end, was almost in extremis between New York and other monetary centres. True, towards the end of August, some sort of New York rate on London, as the Economist remarked, was re-established at a little over $\$ 5$ to $£ 1$, and quotations of a sort were also obtainable with Holland, France and Spain, all, however, quite nominal. ${ }^{2}$

With characteristic energy, New York soon set to work to remedy this serious menace to her commerce. Loans were raised, aggregating $\$ 182,000,000(£ 36,400,000)$, of which $\$ \$ 2,000,000$ was applied to meeting New York's European indebtedness, and $\$ 100,000,000$ to assisting in the rehabilitation of the foreign exchanges. In each case, the amounts raised were in gold, which, under an arrangement with the Bank of England, was shipped to Ottawa, in instalments, and received by the Canadian Finance Minister at an agreed exchange of $\$ 4.90$ to the pound sterling. This, as the Americans point out, was a high exchange for debtors to pay, but shipping conditions made it cheaper than forwarding gold to London.

The effect of this Ottawa arrangement was equivalent to opening a huge credit in London; against the deposit of gold the bankers were placed in the position to draw bills on London, thus providing a means of remittance to those who were under the necessity to settle indebtedness.

A similar arrangement was made by the French Government, which deposited $\$ 6,000,000$ in New York with Messrs. J. P. Morgan \& Co., for the purpose of re-establishing exchange between France and the United States,

1 Cf. International Trade and Exchange, H. G. Brown (New York), page 107.

2 Economist, 22nd August, 1914. 
which, on 31st July, 1914, reached the record rate of $\$ 3.25$ to the dollar.

We have now to examine the other side of the picture, the case where rates, instead of being in favour of London are against us. At the time of writing, ${ }^{1}$ the exchange New York / London, touched the lowest point on record$\$ 4.79$ to the pound sterling, or $5 \frac{1}{4}$ cents below the import specie point, $\$ 4.84_{4}^{1}$ : but gold did not leave England for America, notwithstanding the fact that the rates demonstrated Great Britain to be debtor to the U.S.A. The reason, of course, was that shipping charges, insurances, etc., during the war were prohibitive: but then there was the stock accumulated at Ottawa, which might possibly have been released. As a matter of fact, some of it was sent to New York, ${ }^{2}$ and one of the largest banks, the National City Bank of New York, commenting on this gold held by the Bank of England in Canada, acknowledged the British right to retain the metal, even at some sacrificc. The Bank of England was not, as they said, obliged to receive gold at Ottawa during the autumn of 1914 in lieu of payment in London, but to relieve American distress, it agreed to do so at the rate of $\$ 4.90$, in itself a high rate, yet, in the light of the adverse circumstances, cheaper than shipping gold to London.

In the case just described, the cause of the rate's being so much against Great Britain was our heavy debit balance. During August, 1914, there was a balance of approximately $\$ 19,400,396(£ 3,880,079)$ against New York, but with the re-establishment of exchange and the enormous improvement in America's foreign trade, the monthly balances against London advanced by leaps and bounds, and were given as, September, $\$ 16,341,722$; October, $\$ 57,305,074$; November, \$79,299,417; December, 1914, \$131,863,077; January, 1915, $\$ 145,536,103$.

1 March, 1915.

2 The National City Bank, New York, say a large amount was released at the rate of $77 \mathrm{~s}$. 3 d. per ounce for gold Eagles, equal to $\$ 4.81$ to $£ 1$. 
In dealing with American exchange we have thus examined two extremes; one where exchange went far above the outgoing specie point, and the other where exchange fell below the incoming specie point, and the question arises : how are the sellers of bills affected in such cases? Briefly, with the high rate, say $\$ 6$ to the pound sterling, the seller of sterling bills could only sell his bills at that price to the person who was obliged to remit to Great Britain, and as the latter found it impossible to send gold, he was faced with a heavy loss ; consequently, such conditions spread over a vast number of transactions meant ruin to a large section of the American public, hence the action taken to remedy the trouble.

In the other case, it is the seller of sterling who would suffer. Low exchange indicates, among other things, a large supply of bills, and in times of crisis holders of bills are unduly anxious to obtain cash, even at a sacrifice, and there will thus be a large mass of creditors selling bills at the lower rates rather than wait for the gold which must come sooner or later.

The same principle holds good when it is the banks operating: the high interest rates prevailing at such times, make it unprofitable for either side to be out of its money, even for relatively short periods, as the interest charges will speedily absorb any profit which might be obtainable by importing gold from abroad : the time taken for the gold to arrive is the adverse factor in the case. Some account must also be taken of the increased risk and other adverse factors which we have mentioned, all of which militate against the influx of gold.

In this chapter, it has been possible to touch on but a few of the complex monetary problems arising out of the abnormal situation in which the world finds itself to-day, but sufficient has been said to indicate the force of the economic pressure resulting from the war upon centres both near to and far removed from the scenes of conflict, and all things considered the advantages to any particular country are infinitesimal. 
Since these remarks were written the principal rates of exchange between this country and foreign centres have fluctuated in a remarkable manner. In some cases the levels reached have broken all previous records, and although various remedies have been applied their cumulative effect has not been sufficient to counteract the adverse influences which have arisen since war began. Most of the European nations except Great Britain appear to have abandoned all pretence at maintaining the gold standard; many have also prohibited the export of gold, and in default of gold shipments we are hardly yet in a position to perceive, much less discuss, the final effects of the other correctives which the great financiers of two Continents are seeking to evolve. The full story of the artificial attempts to bolster up the exchanges of the world must therefore form the theme for additional chapters in some future edition, but the way the rates have altered in the few months that have passed since this book first went to press are so striking that we have no hesitation in giving the latest table in order that the reader may be able to digest the figures at his leisure-

FOREIGN RATES OF EXCHANGE ON LONDON-

"ECONOMIST" TABLE OF OCtOBER 9TH, 1915

\begin{tabular}{|c|c|c|c|c|c|}
\hline & & $\begin{array}{l}\text { Lates } \\
\text { Date }\end{array}$ & $\begin{array}{l}\text { est } \\
\text { es. }\end{array}$ & $\begin{array}{l}\text { Rates of } \\
\text { Exchange. }\end{array}$ & Usance. \\
\hline Paris. . & & Oct. & & 27.30 & Cheques \\
\hline Amsterdan & . & ," & 8 & $11.44 \frac{1}{2}$ & \\
\hline Berlin . & . & ," & & $\ldots$ & Short \\
\hline Do. & & & 8 & & 8 days \\
\hline Christiania & . & $"$ & 8 & $17.87 \frac{1}{2}$ & Short \\
\hline Frankfort & . & ", & 8 & .. & , \\
\hline Vienna : & . & ," & 8 & & \\
\hline Petrograd & . & & 8 & $138 \underline{1}$ & 3 months \\
\hline New York & . & ", & 8 & $4.70^{2}$ & Cable \\
\hline Switzerland . & . & ," & 8 & 24.95 & Short \\
\hline Lisbon . & & ," & 8 & $35 \frac{1}{8} \mathrm{~d}$. & At sight \\
\hline Madrid . & & ," & 8 & 24.70 & , \\
\hline Rome . & & ", & 8 & 29.55 & , \\
\hline Rio Janeiro . & & ", & 8 & $12_{32}^{13} \mathrm{~d}$. & 90 dys. st. \\
\hline Valparaiso. & & & 8 & $9_{10}^{3} \mathrm{~d}$ & $90 \quad$, \\
\hline Buenos Ayres & & ", & 8 & $48_{1 \% \mathrm{~d}}^{11}$ & 90 \\
\hline Montevideo . & & ", & 8 & $527 \mathrm{~d}$ & \\
\hline Calcutta. & & ", & 8 & $1 / 4 \mathrm{~d}$ & teleg'ph \\
\hline Bombay . & & & 8 & $1 / 4 \mathrm{~d}$ & transfer \\
\hline Hong Kong. & & ," & 8 & $1 / 9 \frac{7}{8} \mathrm{~d}$ & , \\
\hline Shanghai. & &, & 8 & $2 / 4 \frac{3}{8} \mathrm{~d}$ & $"$ \\
\hline Yokohama. & & & & 2/1d. & \\
\hline
\end{tabular}




\section{CHAPTER XI}

THE EVIL INFLUENCE OF PAPER MONEY ON THE FOREIGN EXCHANGES

IN Chapter VII we referred to the countries having a debased currency-depreciated paper, etc.-and it seems desirable at this point to say something further about the matter.

\section{Paper Gurrency.}

Paper currency is one of those necessary evils which have been handed down to us from our forefathers: its origin seems wrapped in obscurity, but there have been plenty of writers other than economists who have viewed with misgiving the whole-hearted way in which impecunious States have adopted it. Even in the drama of Faust, said to have been written about the end of the sixteenth century, the author makes the Devil the inventor of paper money. The satire is perfectly applicable, but if the Devil had stopped with the invention of paper money his work would only have been half done. In the light of present day experience, the reader may perhaps be inclined to agree that in the centres where the printing press has taken the place of the Mint and depreciated currency consequently is the order of the day, the supreme spirit of evil seems to have gone a step further, and entered into the minds of those who are entrusted with the administration of public financial affairs. In saying this, we have in mind the issues of inconvertible notes, and, what comes to pretty much the same thing, the over issue of notes without the necessary metallic reserves-all in reality are forced issues.

Briefly stated, the effect of such issues, or indeed of any emission of paper currency, is to drive gold out of circulation, but the currency of the country does not 
depreciate, or, to put it another way, prices of commodities do not begin to rise, until the paper exceeds the actual quantity of the metallic currency which has been superseded. When we get to that stage, prices rise in proportion to the increased issues, so that in course of time more money, in terms of the paper currency, will have to be given for the same articles which were previously purchasable for a less sum of the metallic currency; which is equivalent to saying that the currency of a country has depreciated. Curiously enough, this does not affect a country's foreign trade, for importers will still import foreign products, and although the creditor in the foreign centre will get no higher price for the goods, yet the importer will have to part with more of his notes to cover the premium upon the gold necessary for the remittance. Exports also will command just the same price in the foreign country as they did before prices rose in the exporting country. Thus, if in a country with a depreciated paper currency the price of an article had risen from $£ 1$ to $£ 110$ s., and that article was exported to a foreign centre, it would still be worth only $£ 1$, and yet exports would continue, for the reason that in the foreign country the currency not having depreciated, the exporter will receive payment in gold or silver as the case may be. The metal can then be brought to the country with the depreciated paper and exchanged for notes to cover the price and the extent of the premium-10 shillings-for bullion will have risen in the same proportion as other commodities. It is therefore plain that gold, assuming it to be a gold standard country, is at a premium. A striking example of this state of affairs is to be seen in the River Plate, where there is a premium on gold of slightly over 127 per cent.

Although the depreciation of the currency does not affect the foreign trade of the country, it does affect the foreign exchanges. To explain this action, we may take the exchange between two countries, one with a full 
metallic currency, and the other with a depreciated paper currency. Suppose Germany to be the latter country; exchange on London would rise in proportion to the premium on gold in Germany, if the premium were 2 per cent., and the exchange M. 20.40 to $£^{1}$; then a bill of exchange drawn in Berlin on London will be worth more than M. 20.40, since it is payable in gold in Great Britain : the bill of exchange will cost the German remitter M. 20.40, plus the premium on gold, 2 per cent., equal to M. 20.80 to $£ 1$, meaning that the person who has to purchase sterling will have to surrender a greater amount of the native currency than he would if that currency were not depreciated. It follows that the rate of exchange is always against that country which maintains a depreciated currency.

The South American countries are the most notorious for the over issue of paper money, but we have other States nearer home in very little better position. Italy, for example, has always favoured paper, and although of late years the currency position there has improved vastly, there is still an enormous amount of notes in existence. For instance, on 30th November, 1913, the actual currency consisted of 499,293,525 lire of State notes, $2,261,951,200$ lire of bank notes, and about 100,000,000 lire of copper and nickel coin. For this reason the Italian exchange is always very sensitive, and is one of the first to feel the effects of any crisis. The par of exchange is Lire $25.22 \frac{1}{2}$ centesimi to $£ 1$ sterling, and rates are more often against Italy than in her favour. The quotation on 19th March, 1915, was L. 27.80-28.10.

To return to the South American states, the Argentine Republic nominally adheres to the gold standard, the monetary unit of the Republic is the gold peso (sometimes termed the " gold dollar"), which, divided into 100 cents, is the equivalent of 5 francs, but the currency or legal tender unit is the paper peso, and this, at present, is the only circulating money. By an Act passed in 1899, the 
Argentine Government established a Conversion Office in Buenos Aires, and fixed the ratio at which gold coin is received in exchange for paper currency and vice versa. This ratio is 44 centavos gold to 1 peso paper, or, conversely 227.27 pesos paper for 100 pesos gold, $\left(\frac{100 \times 100}{\cdot 44}=227 \cdot 27\right)$ from which it will be seen that there is a premium on gold of 127.27 per cent. The paper dollar being fixed by law at 44 cents gold, $£ 1$ sterling is worth 11.45 dollars paper. One pound sterling is also equal to 5.04 gold dollars.

Brazil is another country which, for a number of years, has had a depreciated paper currency. The exchange, as we have shown in the list of foreign exchange rates, is quoted at so many pence to the milreis, and fluctuates in a striking manner. In 1900 the average rate was $9 \frac{2:}{4} \mathrm{~d}$. ; in $1905,15^{5} \mathrm{~d}$. ; in $1910,16 \mathrm{~d}$.; in 1911-12, 16. 16th July, 1914, it was quoted at $15_{6}^{15} \mathrm{~d}$. to 1 milreis, and on 19th March, 1915, had depreciated to $1358 \mathrm{~d}$. per milreis, the par value of which is approximately $27 \mathrm{~d}$.

The figures in the Statesman's Year Book for 1914, give some idea of the extent to which paper has been issued. At the end of the year 1911, the fiduciary circulation of Brazil was said to consist of 61.8 per cent. of inconvertible notes, and $38 \cdot 2$ per cent. of convertible notes.

Then there is Chile, another one of those countries to feel the full effect of a forced paper currency. Notes, in fact, are the principal medium of exchange. The peso, nominal value 1s. 6d., fluctuates considerably, and its relative value before the war varied between $9 \mathrm{~d}$. and $10 \mathrm{~d}$., but exchange quotations have since been recorded at

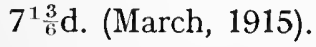

There are, it is manifest, many evils connected with these over issues of paper currency, but the greatest is the frequency of the fluctuations; rates oscillate so often and so wildly that neither producer nor exporter is able to judge with any degree of certainty whether his operations will ultimately yield a profit or a loss. 


\section{Paper Money and the War.}

Some notice ought also to be taken of the issues of paper during the Great War. We have witnessed during the past few months vast emissions of notes by the belligerent nations, and it is almost axiomatic that where, owing to the increasing financial embarrassment, a belligerent nation is compelled to have recourse to the creation of a forced paper currency, and that currency is not convertible in gold, it is sure to suffer considerable depreciation. We have seen in Germany's case the serious fall in the value of her currency, and the discount on the mark is undoubtedly due to the fact that the notes issued by Germany are not convertible in gold. The British Government's notes, on the other hand, are payable in gold on demand, hence in Great Britain's case there is no depreciation in value.

The effect on the foreign exchanges of the depreciated notes is easily perceived. The exchanges are already adversely affected by the interference with the foreign trade, and the advent of the inconvertible paper is merely a further disturbing influence. It accentuates the evils which already exist and its effect is that foreign creditors must either expressly stipulate for the settlement of their claims in gold, or, if payment is accepted in the depreciated medium, to avoid loss, traders must safeguard themselves by a proportionate rise in the exchange. 


\section{CHAPTER XII}

EASTERN EXCHANGES. THE GOLD EXCHANGE STANDARD AS IN OPERATION IN INDIA AND OTHER SILVER-USING COUNTRIES. EXCHANGE REMITTANCES BY MEANS OF

INDIA COUNCIL BILLS AND TELEGRAPHIC TRANSFERS

FOR reasons which will manifest themselves to the reader who has survived the rocks and shoals of the European exchanges, and has the temerity to enter upon the study of what are known as the "Silver Exchanges," we propose to devote this chapter to a study of the gold exchange standard, leaving the fuller discussion of exchange with thuse countries in the Far East whose currency is purely silver, to be dealt with in the next chapter.

\section{Silver Exchanges.}

The uncertain factor with which all concerned in Eastern commerce have to deal is the gold price of silver. Wherever there is this fluctuating silver medium of exchange, foreign trade becomes invested with a speculative element far beyond the ordinary chances and changes of the markets : besides the usual risks of trade, account has to be taken of the risks in exchange caused by the movements in the quotations for silver, and in consequence business operations become converted into gambling transactions, wherein neither expert opinion can guide nor caution protect the shippers. On the one hand, we have the exporters to such countries who find difficulty in calculating the exact amount which will be realized by the sale of their consignments of goods; on the other, we have the importing merchants of the silver-using countries, who are not able to estimate the cost in their local currencies of the remittances in gold which they may be called upon to make in settlement of purchases made from gold standard countries. The greatest uncertainty prevails among both 
sections of the community, for every movement in the price of silver is at once reflected in the exchange between the silver-using countries and those on the gold standard.

That is why silver has come to be regarded as a depreciated metal unduly subject to sentimental influences of all kinds, and as its price has fallen from $60 \frac{\pi}{16} \mathrm{~d}$. in 1872 to about $26 \frac{3}{4} \mathrm{~d}$. in 1914 , there is good reason for the disesteem in which it is held as a currency standard.

\section{India and the Silver Problem.}

The adverse effects upon the trade and commerce of the Indian Empire as the result of the continued fall in the gold value of the rupee, due to the variations in the price of silver, led the Government to consider by what means the evil could be obviated, and much trouble was taken with a view to the establishment of a stable rate of exchange. In brief, the plan the Indian authorities followed was what amounts in principle to a contraction of the existing currency : they closed their mints to the free coinage of silver, and, in 1893, after a somewhat heavy coinage of rupees, the Government ceased to add rupees to the circulation, with the natural consequence that as soon as circumstances led to an increased demand for the coin, the exchange value of the rupee began to rise, and in the course of a few years it became profitable for those who had remittances to make to India, to take advantage of a standing offer made by the Government of India to give rupees at the Calcutta or Bombay mints, or to issue notes at the paper currency offices, in exchange for gold at a rate of exchange equivalent to 15 rupees for $£ 1$ sterling. Once the exchange value of the rupce had reached $1 \mathrm{~s}$. $4 \mathrm{~d}$., the Government's aim was to maintain it at that level with slight variations similar to those seen in the currency between gold-using countries, and after many lengthy and solemn delibcrations in Commission, the authorities seem to have eliminated the disturbing factors in relation to the exchange between London and their own country 
by the adoption of a standard of currency closely akin to the gold standard.

The system in vogue in India is one which Mr. Hartley Withers jokingly terms the half-way house in the matter of currency, since, in his opinion, India has a sort of onesided convertibility in its own favour. The system, however, which has now been in operation, with minor alterations and improvements, for some twenty years, is better and more correctly described as the "Gold Exchange Standard." This standard is in successful operation in far more countries than many people are aware of. In actual practice the currency systems of Russia, Holland, Japan, Austria-Hungary and the Philippines, all resemble India's system. To conform to this standard, the preponderant medium of exchange may be notes or token silver coins, and these, being permanently established, are kept near a fixed par in relation to gold by Government control of the foreign exchanges. With the gold exchange standard it is not really necessary for gold to be in circulation in the country at all, but what the Government must have is the power and ability to sell foreign exchange at a fixed price, and this necessitates their maintaining a reserve in gold, or, what comes to much the same thing, being in possession of resources readily convertible into gold. The silver currency received from the sale of exchange is retained by the Government, and the effect of its being kept out of circulation is the same as that produced by exporting gold. The export of gold turns the exchange in favour of the country exporting, and if the silver-using country is able to supply and maintain the price of bills of exchange with a gold standard country, this will serve the same purpose, and the approximate parity with gold is, ipso facto, maintained. ${ }^{1}$

It has been proved by experience that gold actually in circulation is of very little value in maintaining exchange, and the internal medium of circulation, whether it be silver

1 Cf. Purchasing Power of Money (Irving Fisher), pages 131-2. 
or notes, is largely dependent for its value in exchange, not on its bullion content, but on the possession of adequate gold resources. These resources need not necessarily be kept in the home country: the gold reserve of the Philippines, for instance, is maintained in New York, while Russia, Austria and Japan constantly hold a large proportion of their gold resources in London, Paris, Berlin and other monetary centres. India's Gold Standard Reserve, as is well known, is held in London at the Bank of England.

The gold exchange standard may be better understood, perhaps, if reference is made to the variations of the standard as in operation in two or three of the countries named.

In Austria, as in India, the use of notes and silver coins has become ingrained among all classes of the population. Before the war, and there is no reason to suppose that currency conditions will be materially altered after the war, the Austrian Government's irredeemable paper currency had given place to the inconvertible bank notes of the Austro-Hungarian Bank, which are issued against cover consisting of metal, bills of exchange and loans. The Austrian law regulating this bank's issues, admits of its holding a proportion of the cover for the notes in foreign bills payable in gold, and the bank is also allowed to deposit a part of its assets abroad payable on demand. By this means the bank, representing the Austrian Government, was able to keep the Austrian currency, in the shape of the bank's inconvertible notes at, or near par. These notes ale the predominant medium of exchange in Austria, and the bank, before the interruption of communication caused by the war, was able to keep them at par in relation to gold by selling exchange against its foreign assets payable on demand, and by meeting the demand for remittances to other countries by selling foreign gold bills, say on London, Berlin or Paris.

The currency in the Philippines is manipulated in a similar way, the silver pesos or coin certificates being 
maintained at the par of exchange within the limits of variation that apply in the case of the exchange between countries whose currency is mainly gold. It is rarely possible to obtain gold coin for silver in the Philippines, except in small quantities, but as drafts on New York are always procurable from the Government at par, plus the usual charges for exchange between gold standard countries, ${ }^{1}$ thesc are equivalent to gold exports, and serve to keep exchange steady.

Besides the maintenance of satisfactory resources, the system therefore calls for the contraction of the currency by the retirement of a sufficient amount of the silver coinage whenever it is apparent that more is in circulation than the demands of trade require. Expansion of the currency is produced by the release of this currency to circulation, or by the issuance of new currency whenever it is seen that there is a shortage of the currency medium.

It seems to be an essential part of this system that the intrinsic worth of the silver coins should be fixed by law above the value of their silver content: without such proviso the power to control the circulation would exist in one direction only-contraction: with the margin between the coin value and the bullion value, the power exists to expand as well as to contract, and it will be seen that in countries where the gold exchange standard is in operation, care has been taken to divorce the value of the silver coins from their bullion content. ${ }^{2}$

The limited space at our disposal precludes the multiplication of examples, but we may conclude with a summary of the results seen in the case of India.

As is well known, by reason of the enormous export trade from India, the balance of her international credits and debits is nearly always in her favour, which accounts to some extent for the large amount of precious metals

1 The actual charges are three-fourths of $1 \%$ for demand drafts and $1 \frac{1}{8} \%$ for telegraphic transfers : the premium may be temporarily increased or decreased should circumstances call for the alteration.

${ }^{2}$ Cf. Purchasing Power of Money (Irving Fisher), page 338. 
annually imported into India. This was also the case before the adoption of the present system of currency, but whenever there was a falling exchange, the adverse effects on the silver currency made themselves felt. Events went to prove, in fact, that in saying that where a country is upon a silver standard, it is as well to maintain that standard if it is desired to stimulate the development of the country in regard to its exports, currency experts lost sight of one important point. Where the currency is depreciating as compared with gold, exports do increase, but the increase is partly due to the larger volume of goods which must be exported in order to liquidate the country's debts to gold-using countries. If silver is at $30 \mathrm{~d}$. per ounce and falls to $25 \mathrm{~d}$. per ounce, the silver currency unit falls with it, and the difference in value has to be made up by sending more goods.

This was precisely what happened with India, and consequently the fluctuating value of the rupee made trade both uncertain and unsatisfactory. With the divorce of the value of the rupee from that of its silver content, fluctuations in exchange due to the fall in the gold price of silver were removed. There still remained the danger, however, that if ever the balance of indebtedness was against India, the value of the rupee would depreciate unless steps were taken to prevent this. It is apparent in seasons of ordinary prosperity that no effort is needed for the maintenance of the rupee at $1 \mathrm{~s}$. $4 \mathrm{~d}$., since the favourable balance of trade would ensure a sufficiency of foreign bills being forthcoming for those who require to make remittances. When the favourable balance is seriously diminished, or the balance becomes temporarily unfavourable, it is clear that India's claims on foreign countries in the shape of bills of exchange will be relatively scarce, and those who are under the obligation to remit sterling to Great Britain would be forced to pay a larger number of rupees for each sovereign the bill of exchange represents. This indicates a falling exchange, and as we 
have seen, in such circumstances exchange continues to fall until it reaches that point when it is more profitable to send gold than to remit bills to the creditor country. So far the procedure is simple, but the difficulty, more apparent than real, is that in practice no gold might be available for export, since, although there is a legal obligation to issue rupees in India in exchange for sovereigns, there is no corresponding legal obligation on the Government to give sovereigns in exchange for rupees. Consequently, if no safeguard existed, the rupee would fall till it was worth no more than its silver value at the rate of the day. To meet this contingency, there are available, besides the general resources and credit of the Government of India, the gold held in the Paper Currency Reserve, and, more particularly, in the Gold Standard Reserve, which was specially constituted for this purpose. These reserves are kept in London and India, and at the present time amount to a very substantial figure, and although there is no statutory obligation on the Government of India to take special measures to maintain the value of the rupee at $1 \mathrm{~s}$. $4 \mathrm{~d}$., they have expressed their determination to support exchange up to the limit of their resources.

When exchange between India and Great Britain shows signs of falling below 1s. $3 \frac{9}{2} \mathrm{~d}$., the Indian Government intervenes by selling sterling bills on London at this rate. They took action in this way in 1907-08 and 1908-09, when sterling drafts on London to the extent of $£ \$, 058,000$ were sold at $1 \mathrm{~s} .3 \frac{9}{2} \mathrm{~d}$. per rupee to assist in the balance of trade, and again when exchange dropped as the resuit of the financial disturbance which accompanied the outbreak of the recent hostilities in Europe. On the latter occasion the Government offered these "Reverse Councils," as they are called, in the shape of telegraphic transfers on London as an alternative to bills. This action had for effect the maintaining of exchange in the neighbourhood of the gold export point from India, and the fact that this 
value was maintained throughout August, $1914,{ }^{1}$ while the currency of other countries more favourably situated abnormally depreciated, is a striking testimony to the efficacy of the Indian arrangements. Moreover, it demonstrates the wisdom of keeping a part of the gold reserves in London.

\section{Council Bills and Telegraphic Transfers.}

This chapter would be incomplete without some explanation of the manner in which the sales of Council Bills and telegraphic transfers on India by the Secretary of State in London are carried out. These sales are considered to be the central feature of the machinery by which the Indian finance and currency system is at present managed. We have, so to speak, two bodies in the open market: on the one hand, the Indian Government requiring English currency for the purpose of paying for its purchases of bar silver, interest on loans contracted here, pensions due, and services rendered; on the other, a group of bankers, financiers and importers of Eastern produce, desirous of settling their indebtedness to India in rupees. The Indian Government want sovereigns in London to pay their home charges, while the bankers and others need silver rupees or paper currency in India. This latter class know that there are only two ways of procuring rupees from the Government in India : a banker or merchant may present Council drafts, purchased in England at varying rates per rupee, or he may tender sovereigns in exchange for rupees at the fixed rate of 1s. $4 \mathrm{~d}$. In ordinary times it suits the remitters to send out these bills purchased in London.

As far as the Indian Government are concerned, they inherited this method of drawing funds from India from the old East India Company, and as the system is found to be a convenient one for all parties, the India office have

1 In August, 1914, the Government announced that they were prepared to sell drafts on London at $1 \mathrm{~s}$. $3 \% \mathrm{~d}$. and telegraphic transfers at $1 \mathrm{~s}$. $31 . \mathrm{d}$., to the extent of $£ 1,000,000$ weekly, in support of exchange until further notice. 
continued it down to the present day. The practice in principle amounts to the selling of rupees to the highest bidder, and the Indian authorities in London have made arrangements whereby would-be remitters may make definite offers, through the medium of the Bank of England, for so many lacs of rupees-a lac being equal to 100,000 rupees.

The plan followed is this: each Wednesday a notice is exhibited at the Bank of England stating the aggregate amount which will be allotted, and tenders are invited for the bills of exchange and telegraphic transfers on the Indian Government authorities at Calcutta, Madras and Bonbay. There is no obligation to allot the whole amount stated, and as a rule, applications at prices lower than 1s. $3 \frac{2}{2} \mathrm{~d}$. per rupee for the bills and $1 \mathrm{~s} .3 \frac{15}{6} \mathrm{~d}$. for transfers receive no allotment. Each applicant specifies at which place he desires to receive rupees, and if it is necessary for him to have funds immediately available at one or other of the centres named, the remitter will apply for telegraphic transfers; but if a remittance by mail will suffice, he tenders for the drafts, and in the latter case, as the India Council has the use of his money for two or three weeks before rupees are paid over in India, a lower rate will be paid for the drafts than for the transfers, due allowance having to be made for the interest on the money. As a matter of fact, the price charged for telegraphic transfers is ordinarily higher by $\frac{1}{3} \mathrm{~d}$. per rupee than that charged for bills, but when the Calcutta or Bombay Bank Rate exceeds 8 per cent., tenders for transfers rank for allotment with tenders for bills only if they are $\frac{1}{16} \mathrm{~d}$. higher. Allotments, of course, are made to the highest bidders, the price varying in proportion to the intensity of the demand: the more the remittances are needed the higher will be the rates offered, and as in such times the total amount tendered for exceeds the amount offered, allotment is made pro rata.

Each Wednesday, as soon as the tenders have been 
examined, a statement is issued giving the total applications, the allotments, and the amount to be offered the following week. These particulars are available on Wednesday afternoons.

Remittances can also be purchased on other days in the week, and the price charged is fixed by the India Office at not less than $3 \mathrm{~d}$. higher than the lowest prices at which allotments have been made on the preceding Wednesday. Bills and transfers obtained in this way are termed "Intermediates " or "Specials," and the exact rate chargeable, together with the maximum amount to be sold is fixed for the week each Wednesday.

The primary object of this Government dealing in bills of exchange and telegraphic transfers was really the laying-down of funds in London to provide for the Secretary of State's Home Charges, but witl the efflux of time and the necessity for maintaining the exchange value of the rupee, the system has been extended to meet other requirements. It was temporarily suspended when the Government decided to force the exchange value of the rupee up to $1 \mathrm{~s}$. $4 \mathrm{~d}$., and later, in 1898 , sales were resumed as a means of altering the location and disposition of the general resources of the Government of India, and thus provide the means in time of monetary stringency whereby currency could be readily and quickly expanded. Finally, the sales of these bills are so regulated as not only to meet the requirements of the Secretary of State for India, but also to satisfy the demands of trade up to such an amount as will enable the balance of trade in India's favour, over and above the amount of the Home Charges, to be settled without the export to India of more gold than is actually required there for absorption by the public. 


\section{CHAPTER XIII}

THE EASTERN EXCHANGES (CONTINUED). CHINA AND

THE SILVER PROBLEM

WE have seen in the case of India that although the silver rupee is still the currency unit, yet the Government have formulated rules and regulations by which the exchange value is efficiently controlled, notwithstanding the fluctuations in the price of silver.

\section{Gurrency of China.}

With China, however, the position is not so satisfactory. Speaking generally, we say China is on a silver basis, but it is very difficult to say what exactly is the currencyeach province seems to have its own ideas on the subject, and silver is legal tender for any amount and in any shape, national or otherwise. As far as the actual money of the people goes, the principal coin in daily use is the copper cash, worth anything from one-thousandth to an eighteenhundredth of a tael. It is a very small copper coin, the modern replica of the li, which coin is said to have been in use in China for more than 3,000 years. The British community know the coin as "cash," but the French call it sapèque.

The tael is not only the name given to a coin, but it is also the unit of weight which is in use all over China, and is taken to represent a Chinese ounce of silver, equal, according to the British standard, to 583.20 grains troy, but it varies considerably in different provinces. ${ }^{1}$

The Mexican dollar also circulates in many places, and in the British Colony of Hong-Kong this dollar is widely used, but even there it is not the only currency

1 In A.D. 1696 a tael of silver was worth 1,750 cash; in 1889 , it was worth 1,380 cash ; in $1905,1,840$ cash; and in 1914, about 1,400 cash. The value has varied between 3,000 and 9,000 . (S. R. Wagel, Finance in China: Shanghai.) 
unit. Indeed, as far as Hong-Kong is concerned the position can only be described as unique. Chopped Mexican dollars ${ }^{1}$ and British dollars form the circulating medium, but the dollar quoted in the exchange rates is that represented by the notes of the three British banks established there. The equivalent of these notes in terms of gold is, in fact, the basis for all foreign exchange settlements in the Colony of Hong-Kong.

We have no space to go fully into the Chinese currency system-it would need several volumes to describe adequately the existing state of affairs, but some idea of the difficulties with which one has to deal may be gauged from the fact that not only does the tael as a weight, vary, but also its value as a currency medium: there are often wide differences between the taels of Shanghai, Peking, Hankow and Haikwan. Apart from these, the Chinese make payments by weight in silver bullion, known as sycee, ${ }^{2}$ i.e., fine silver, made up in the form of small ingots weighing approximately 50 taels. These pieces of silver are termed "shoes," and although they form an essential part of the monetary circulation in China, their issue is not directly under the cognizance of the Government: the making and assaying of the shoes is largely in the hands of those who cast them and of the bankers and money changers.

The dollar coin, however, makes its appearance in many domestic and retail transactions, and as there are nearly a dozen kinds in circulation, the variation in value may better be imagined than described. The Mexican dollar is the one most favourably received, and there is consequently a greater number of those coins in circulation than of any other form of silver dollar. Various subsidiary silver coins, 5,10 , and 20 -cent pieces, are also in circulation, and the existing chaos is not lessened by the fact that

"A " chopped " dollar is one bearing the "chop" or trade mark of the native dealer.

2 This term is derived from the resemblance of the metal to sai ssit (fine silver). 
some of the provincial mints are allowed to issue these subsidiary coins when it suits their convenience, for purposes of revenue.

If there are variations in the value of the silver currency in the interior trade, there is very little wonder that difficulties are encountered when it is a question of foreign trade. It is acknowledged that commerce between gold standard countries is satisfactory to all classes of traders, for both importers and exporters know exactly the return they may expect, but in trade between a silver-using country and one on a gold basis, a large measure of uncertainty invariably exists. Whenever there is a fall in the gold value of silver, either the exporter in the gold standard country, or the importer in the silver country must suffer.

Let us take the case of the exporter. We will suppose that A. Blank \& Company, of Manchester, calico printers, send goods to Shanghai, which they hope to sell there for a total sum of, say, $£ 1,000$. The price of silver when the shipment was dispatched was, we will say, 25d. per standard ounce, and on this basis A. Blank \& Company have calculated the selling price which is to yield them $£ 1,000$. By the time the calico arrives in Shanghai, the gold price of silver has dropped, we will suppose, to $20 \mathrm{~d}$. per standard ounce, and this obviously indicates that the manufacturers will receive one-fifth less for their wares, since they are paid in the currency of the province (taels in this instance), and when Blank \& Company's money comes to be converted back into British gold pieces, they are face to face with the fact that the outturn is $£ 200$ less than they had calculated: they have lost one-fifth, and receive $£ 800$ only. This is, of course, an extreme case, as in the ordinary course silver would be unlikely to drop $5 \mathrm{~d}$. in the period between shipment and arrival of the goods in Shanghai; but whatever the fall, the principle is the same, and the illustration serves to show exactly what happens. 
It is not only the British exporters who stand to lose in the lottery of trade with countries which have an unstable silver exchange; the capitalist also, and every class of investor, is liable to be adversely affected in operations with silver standard countries. The rate of exchange between such countries and gold standard countries is plainly the exchange between gold and silver, therefore, if a person has invested in undertakings in the silver country, when he receives his dividends in the currency of that country, he will obtain less for his dividend warrant on the London market in proportion to the fall in the price of silver-assuming that it does fall. Conversely, he may reap a higher return on his investment if silver has gone up before the encashment of his dividend.

Finally, the principal is affected in the same way, when ever it is desired to convert it back into gold. A further example will show how this works out in practice.

We may assume that an investor, encouraged by the chance of earning 6 per cent. on his money, remits to China $£ 1,000$. The price of silver on the 1st January, 1914, was $26 \frac{7}{16} \mathrm{~d}$. per ounce standard; on the 31st December, $1914,22 \frac{1}{1} \mathrm{~d}$. For the sake of argument, we will imagine our investor sent the money out to the Eastern country on the 1st January, 1914, but circumstances made it advisable for him to recall his money at the end of December in the same year, when the metal had depreciated to $22 \frac{1}{1} \frac{1}{\mathrm{~d}} \mathrm{~d}$; in converting his principal back to British currency he will find himself faced with a sharp loss. Silver, in which the investment stood, has dropped $33 \mathrm{~d}$. of its gold equivalent, roughly, one-seventh; consequently on conversion the gold value of his original $£ 1,000$ has fallen to about $£ 857$.

We may now leave the general question of the adverse effects of this depreciating silver currency medium, and pass on to a consideration of those exchange questions with which we are more particularly concerned in this book. 


\section{Exchange Rates.}

In the table given on page 40 it will be remembered the exchanges of these silver standard countries were quoted in shillings and pence to the dollar, tael, or rupee, as the case may be, that is, the gold value of the respective silver coins. Hong-Kong, for instance, is quoted 1s. $10 \frac{3}{8} \mathrm{~d}$. to the dollar, and Shanghai, 2s. $5 \frac{5}{8} \mathrm{~d}$. to the tael. The rates from these centres, as was explained, indicate the price for telegraphic transfers on London: the unit of exchange in the centres named being by general consent the rate for telegraphic transfers on London.

Let us take the Shanghai rate as an example: 2 s. $5 \frac{5}{8} \mathrm{~d}$. per tael, means that for every silver tael the remitter hands over to the exchange bank in Shanghai, 2s. $55 \mathrm{~s}$., or, to give it its real significance, a little less than one-eighth of a sovereign in gold, will be paid to the person in whose favour the remittance is made, as soon as a telegram can reach the bank's London branch.

Now, although the newspapers content themselves with giving the telegraphic transfer quotations only, Eastern bankers from whom they obtain the details, quote additional rates, and as the student may be called upon to carry through transactions, it will be well to refer to the other quotations. Besides the T. T. rate, as it is called for the sake of brevity, we have the four months' sight and six months' sight rates, which are the quotations for firstclass bank bills. Both quotations are higher than for the telegraphic transfers, ${ }^{\mathbf{1}}$ that is to say, for every silver tael paid in Shanghai the bank will allow more shillings and pence where it is a question of paying the gold value in London four or six months hence, than it would if the payment is to be made on demand or by wire. The reason

1 In addition to the T.T. rate, the banks quote a rate slightiy higher for demand bills. The T.T. quotations given in the Press are what exchange dealers call the "selling rates" ; but the foreign banks also wire to their London agents the " $4 \mathrm{~m} / \mathrm{s}$. L/C." quotation, which is the "buying rate." On the day the Shanghai T.T. came forward as " $2 / 5 \frac{5}{8} \mathrm{~d}$.", the $4 \mathrm{~m} / \mathrm{s}$ buying rate was $2 / 5 \frac{7}{8} \mathrm{~d}$. As a rule, outward remittances from London cost about $\frac{1}{8} \mathrm{~d}$. over these rates. 
is, that if a bill drawn on London, payable four months after sight, is sent, the remitter is bound to place the receiver in such a position that if the latter chooses to turn the bill into cash after it has been " sighted " and accepted, he will not be worse off than if the money had been sent by cable.

The rate for these time bills is thus in a large measure dependent upon the rate of discount ruling in the centre upon which they are drawn. But the reader may very well remark that the banks in the East at times play the role of buyer. This is so; there is no difference in the factors governing the price they will pay for merchants' bills drawn on London; in this case also cognizance is taken of the discount rates ruling in London, or upon whatever centres the bills are drawn, and in each instance some account must be taken of the charges for stamp and other incidental items to which we have referred in discussing Continental exchanges.

As may be gathered, therefore, the discount rates ruling on the London market are of great importance to the Eastern bankers and exchange dealers: so important are they in fact, that it is necessary for each side to keep in direct telegraphic communication regarding the existing discount quotations and the probable trend of the markets.

As we saw when examining the principles which govern the sales of bankers' bills by the European bankers, and bankers in gold standard countries, it is the rate at which they are able to cover their drawing operations which governs the price at which they will sell bills. If a banker has funds deposited with his correspondent upon which he can draw, well and good: if he has no balance with the agent, he must either provide the wherewithal to meet the bills which he has drawn, or, alternatively, he can instruct the agent to draw on him in reimbursement. Finally, there comes a time, as we pointed out, when, as all other means of placing his correspondent in funds have been exhausted, the banker will be obliged to ship 
gold in cancellation of his indebtedness. The position in regard to silver countries is exactly the same, the only difference being that the bankers will, as a last resort, ship silver to be sold for what it will fetch.

With the depreciating silver standard, they have not the advantage of having a fixed price for the metal upon which operations can be based. Gold, on the other hand, as shown in the various illustrations we have given, has a fixed rate at which it is received in all the gold standard countries, and the mint parity forms a reliable and convenient basis upon which exchange is calculated between the various centres. It is not so with silver; there being no fixed price for silver, it is impossible to state a definite ratio for calculating the par of exchange between gold and silver using countries. All we can say is, that the rate of exchange depends upon the gold price of silver as fixed upon the London market each day; hence it follows that the quotation for telegraphic transfers, upon which all other rates in silver countries are based, is itself governed by and follows the fluctuations in the price of silver.

Experts in Eastern exchange have even attempted to define the specie points with these silver-using countries, and the following details, summarized from remarks made by Sir Charles Addis on the subject, ${ }^{\mathbf{1}}$ may perhaps better illustrate the course of these silver exchanges.

The rate of exchange, it may be noted, although subject to the variations in the gold price of silver bullion, does not always respond to these changes, yet, broadly speaking, the gold price of silver is taken to form the limit above which, after adding importing charges, exchange cannot rise, and below which, after deducting export charges, it cannot fall. ${ }^{2}$

1 In an address to the Shanghai Literary and Debating Society on "The Daily Exchange Quotations."

2 Some of the French experts prefer to use the expression "relative par" as more correctly describing the relation between gold and silver. The author of Le Portefeuille (M. P. Lepeltier), whose remarks we translate, says that this abstract expression is used to indicate that the exact ratio cannot be fixed, sirce in one 
A banker, then, in selling bills, is guided by the price of silver, and he will not draw and sell bills on his London branch over a lower silver price (or higher exchange) than he can purchase the same quantity of silver elsewhere, plus the cost of shipment to the centre in which he is operating. It must be remembered that the banker in this case is actually selling claims to gold in exchange for the silver he receives. The reverse operation is seen where the banker buys bills of exchange (claims to gold) on, say, London. In this instance he gives silver in exchange, and will not pay a higher silver price (which is a lower exchange) than that which would be obtained if he sold the silver for gold on some other centre: in this case it would of course be less the cost of transmission.

In view of these factors, it necessarily follows that the gold price of silver is the fundamental basis for fixing the rate of exchange in the East, and taking Shanghai as the place from which we are operating, the exchange quotation is taken to be above the silver price when it exceeds the gold price at which the given quantity of silver, after adding the cost of importation, could be laid down in the centre named, and so much lower than the silver quotation when it is below the gold price at which the same quantity of silver could be sold in London, after deduction of exporting charges.

It is fairly clear that the real trouble in Eastern exchange lies in the fact that we have three main factors to deal with instead of two. In the gold exchanges we have simply the demand for and supply of bills and telegraphic transfers; in the silver exchanges the matter is complicated by the way in which we also have to depend upon the fluctuations

of the countries gold will be merchandise, and in the other silver will be merchandise : consequently each will have a variable price like that of all other merchandise. The fluctuations in the price of silver in the country which considers it as a commodity will be in an inverse ratio to the price of gold in the other country : if the price of silver goes up in the first country, the quotation for gold will fall almost methodically and in the same proportion in the other country. 
in the price of silver on the London market. We have seen how the alterations in the price of silver affect exchanges. As far as the fluctuations resulting from the interaction of the demand for and supply of bills are concerned, it may be said that they are exactly similar to those seen in drawing and remitting bills between gold standard countries. With a limited supply of bills and a keen demand, there will be competition among the banks for the paper, and the silver price will rise, or, stated another way, exchange will fall. Conversely, if there is an abundance of exports many mercantile bills will be offering, and merchants will take a lower silver price for them, that is, exchange will rise.

For the rest, the case of China affords a useful illustration of the point we have once or twice emphasized in this work, that is, it is the country drawing the bills which really settles the rate of exchange. We have already stated that where there are two countries trading together, one set of bills serves to liquidate the double indebtedness which arises, and with the exchange business between China and Great Britain the same principles apply. John Chinaman number one draws on London for the value of his exports, while John Chinaman number two remits to London (through the intermediary of the bank) for the cost of the imports, and the one bill serves for the two transactions. That explains in one way why the rate of exchange is fixed in the centre drawing the bill, say, Shanghai: the other factors governing the case are explained by the banker ${ }^{1}$ we have already quoted, somewhat in the following terms.

Shanghai draws on London for the cost of her exports and remits to London for the value of her imports, and the principal reason for this procedure is that the manufacturer in Great Britain does not wish to be bothered with the variations in exchange, although, as the reader has seen, he may be pretty severely affected if silver has

\footnotetext{
1 Sir Charles Addis.
} 
depreciated before his goods are sold. Leaving that out of the question, however, we may take it that as all his expenses are payable in gold, he naturally prefers to deal in terms of that metal. Consequently, goods shipped to China are nearly always paid for by remittances, or drawn for in sterling, which comes to the same thing. The Chinese producer is on rather a different footing. His expenses are in silver, and in silver he wishes to be paid. His produce, however, he has sold to Great Britain for a gold price, and either he cannot afford to, or does not want to wait until a remittance can be sent by mail from London. The one way open to him is to draw in sterling and settle the rate of exchange on the spot, which he does and so makes an end of the matter.

It only remains to add that, apart from the fluctuations in the silver exchanges caused by the unstable condition of the currency, there is no difference in the causes which influence rates. All those factors in the fluctuations which fall under the heading of demand and supply of bills in gold countries, namely, trade conditions, Stock Exchange influences, and banking influences, are present in the silver exchanges, and if this is borne in mind there need be as little difficulty in mastering the theory of exchange with the countries of the East as there is with the countries of the West. 


\section{CHAPTER XIV}

THE METHODS BY WHICH OPERATORS ENDEAVOUR TO

ELIMINATE EXCHANGE RISKS. EXCHANGE AS

PER ENDORSEMENT. FORWARD EXCHANGE

In countries where exchange is subject to sudden and violent fluctuations the question as to who shall bear the loss, if any, is one which causes all concerned in the transaction furiously to think. One more or less satisfactory way out of the impasse is to draw the bills with the clause "Exchange as per endorsement." The object of endorsing the rate of exchange on the bill is to transfer the liability for any loss in exchange on to the foreign importer, that is, the person on whom the bills are drawn.

\section{" Exchange as per endorsement."}

The drawers of sterling bills on foreign centres usually insert the clause in bills before handing them to the bankers for sale, and hitherto it has been the practice for the bankers to complete the clause by endorsing on the bill the rate of exchange, and the drawer is then paid the amount of the bill less the usual commission and charges. This method has been found to work well so long as the rate of exchange was not too much against the foreign drawee when time for payment arrived, but at the present time, owing to the increasing number of cases in which the persons on whom bills of exchange are drawn refuse to pay the equivalent at the rate of exchange endorsed on the bills, the custom among some of the bankers is to quote the seller of the bill the rate and insist on his endorsing it on the bill himself. Under this arrangement any dispute which may subsequently arise when the bill is presented can be referred back to the drawer for settlement between the drawee and himself. 


\section{Forward Contracts.}

So far we have considered that all bills, etc., are bought or sold on the spot, but in countries having an unstable currency, there is a method by which both importers and exporters seek to remove some of the risks attendant upon the fluctuating exchange: they make forward contracts with the exchange banks for the purchase or sale of bills and telegraphic transfers as and when favourable opportunities present themselves. To the novice these operations may appear somewhat technical and involved, it will therefore be well to set out separately one or two of the transactions as they occur in actual practice.

First of all take the case of the British exporter who has consigned goods to China. His agent there (the importer) has a ready market for the consignment, and is under agreement to put his principal in England in funds by a certain date; he knows approximately the amount he will be obliged to remit to Great Britain, and to avoid the exchange risks he makes a contract with one of the exchange banks in China, Shanghai, for instance, for the purchase of a telegraphic transfer on London, deliverable on the date required, at an agreed rate of exchange. This is termed buying forward exchange, and the rate is called the "forward rate." When the date arrives the sum due is paid to the Bank in Shanghai in taels, and the remittance is forthwith sent by cable to the bank's London branch for payment to the British exporter, or whoever else is concerned, in sterling.

Forward contracts for the purchase of bills from exporters from a foreign country to England serve a double purpose. They eliminate the risks of exchange both for the exporters who wish to have a certain fixed sum paid in exchange for their bills, and also for the importers who are under the obligation to remit by mail to the British or other exporters. For example, the Chinese exporters of the tea which arrives in England during August, know as far back as April or May that they will have to draw 
sterling bills on firms in London, and if the exchange quotations are favourable they will endeavour to make forward contracts with the bankers to purchase the tea bills, deliverable, say, two or three months hence. So much for the Chinese exporter, but there is also the importer who desires to operate in the reverse way. In his case he may perhaps want to make a remittance by mail in payment of cotton goods he has imported from Manchester, and knowing the date the funds ought to leave China, he can contract with the bankers in advance for the remittances at any time the rate appears suitable. We are, of course, assuming in each case that the banker is willing to operate; but it sometimes happens that the exchange dealers consider they have sufficient forward exchange commitments, and in that case they will refuse to make offers.

It now begins to dawn upon us how the astute banker can set one operation off against the other. He is under contract to pay the tea exporter, say, $£ 1,000$ on the 31 st July: on the same date the Chinese importer is under contract to pay him $£ 1,000$ to remit to London. Further explanation is hardly necessary. With the funds received from the importer the banker pays the exporter for the bills the latter delivers, and, finally, the bills are sent to London to be turned into cash by the bank's London office, who will pay in good time the person to whom the Chinese importer has remitted.

As regards telegraphic transfers, forward contracts must be covered by the bankers, and this is done by their purchasing bills of exchange drawn on the same centres as those upon which they have sold telegraphic transfers. For instance, if a banker has sold telegraphic transfers on London three months forward, he will endeavour to purchase bills of exchange to mature in London on the same date as that on which the telegraphic remittance will have to be paid. The proceeds of the bills falling due in London therefore form the fund out of which he pays the telegraphic transfers. 
To avoid misconception, it should be noted that in the case of these telegraphic transfer contracts, no payments are made by the contracting parties until the date when the contracts are taken up.

Once the contract for forward exchange is made, the risk on exchange fluctuations is transferred from the exporters and importers to the banker, and the margin of profit which the latter has made on the rates will be increased or diminished in proportion to the rise or fall in the exchange. Events sometimes favour the one class of operator, sometimes the other, and while the traders say it is the bankers who always reap the gain, the banker solemnly avers that his margins are reduced to the narrowest possible point by the very good rates the traders exact when selling him their mercantile bills. However, like so many other operations we have investigated, the bankers' profits depend upon the rates at which they ultimately make purchases to cover their forward sales.

For the rest, the speculation being transferred to the bankers, it is they who stand to lose should exchange go against them, and it is they who will have to make shipments of the precious metals if for any reason there is a shortage of cover for the contracts they have entered into.

This concludes our examination of the general theory and practice of Foreign Exchange. In the following chapters we shall discuss the various forms of credit instruments which represent the outward and visible sign of international indebtedness. 


\section{CHAPTER XV}

ON CREDITS. TRAVELIING LETTERS OF CREDIT. THE SIMILARITY AND DISSIMILARITY OF CONFIRMED AND UNCONFIRMED CREDITS, IRREVOCABLE CREDITS, CLEAN CREDITS, DOCUMENTARY CREDITS, LONDON ACCEPTANCE CREDITS, AND REVOLVING CREDITS

THE wisdom the reader has acquired, or which we hope he has acquired, from a study of the preceding pages will be of little avail unless the acquisition be coupled with understanding. Experience and knowledge are both excellent qualities, but either or both are of small utility unless their possessor has the power of applying them critically or practically. The drift of this thin attempt at moralizing is that we shall have spent our time to little purpose unless we are sufficiently conversant with the instruments which serve as the international media of exchange to be able to explain their place in that great fabric, the world's credit system. To arrive at a correct understanding of the many and varied foreign bills of exchange in existence, then, we must start by investigating the forms of authority under which they are drawn.

\section{Travelling Letter of Gredit.}

Since the ordinary travelling letter of credit is familiar to most people, we may take that as a starting-point. It may be defined as a request from a banker to his foreign correspondents to cash on demand the drafts of the holder of the letter of credit on the issuing bank, the latter undertaking to mect the drafts when presented. Persons purchasing these letters of credit from the banks usually pay cash down, plus a commission of about $\frac{1}{2}$ per cent. on the total amount of the credit, although if the credit is desired by a good and influential customer of the bank, it is not unusual to issue it free of commission. It sometimes 
happens, too, that a bank or finance house of high standing purchases a letter of credit from a bank with foreign branches, and where the amount is paid at the time of issue, the credit would be granted free of charge.

If a travelling letter of credit is granted for use on one centre only, the banker will immediately on issue advise his correspondent, and at the same time send him a specimen signature of the beneficiary. In most cases, however, travellers require money to be available in a large number of cities, and as it would not be possible to advise and distribute specimen signatures ad infinitum, the credit is drawn up in such a form that it bears a space for the accredited party's signature, which can be compared by the banker with the signature of the person who subsequently presents the letter of credit.

Each letter of credit has with it a list of the bank's branches or correspondents in foreign towns, and when the holder is abroad reference to this list will show him where he can obtain cash. Payments under the letter of credit are made in exchange for either a signed receipt or a draft drawn to the order of the paying banker: some correspondents prefer one form, some the other, although in practice both documents are really treated as demand bills. Each instrument bears, besides the usual particulars, the number of the credit and the date. It is the foreign correspondent who hands these bills for signature to the presenter of the letter of credit, and after he has satisfied himself that everything is in order, the correspondent enters the amount drawn on the back of the credit, and then pays the equivalent in local currency at the rate of the day for demand bills on London. The draft or receipt is subsequently dispatched to London for payment by the issuing bank, and on arrival it must be stamped with a penny stamp-the Inland Revenue duty on cheques or bills payable on demand or at sight.

Sometimes foreign banks charge a small commission for encashing drafts under letters of credit, but more 
frequently they obtain their profit in the rate of exchange at which the amounts drawn are converted into local currency.

\section{Confirmed Banker's Credit.}

Another form of credit often issued by home, foreign and colonial banks, is what is known as a confirmed banker's credit.

A confirmed banker's credit may be defined as a credit opened by a banker, setting forth certain conditions and stipulations under which he agrees to accept the bills drawn by a foreign shipper, as and when presented to him, up to a certain specified sum. This document is largely used in financing foreign trade, which need not necessarily be confined to this country: although the credit may be opened from London, it may refer to shipments from the foreign country to Continental centres.

The commission charged is usually about $1 \frac{1}{2}$ per cent. per annum on the amount drawn under the credit, but varies, of course, in different institutions, according to the standing of the firms requiring the accommodation, and the risks involved. It should he noted that the banks do not like to issue these credits for more than six months; they prefer to limit their risk to that period.

A confirmed banker's credit will be better understood if it is pointed out that the credit is generally opened by a bank or finance house on this side, at the request of an importer, for the purpose of enabling a merchant or shipper abroad to draw bills on the bank against shipments, say, to London. The bank granting the confirmed credit undertakes to honour the shippers' bills, if drawn in accordance with the various stipulations in the credit, and the credit often contains a clause similar in form to the following: " and we hereby undertake to accept bills as drawn on presentation by a bonâ fide holder."

In the face of this clear and unequivocal clause, it is plain that drafts drawn under the confirmed bank credit 
must be accepted provided the provisions of the credit have been carried out correctly. The position, however, is not so clear in the case of the revocation of such a credit. It is a moot point whether it is politic or even admissible to revoke such a credit after confirmation by the drawee bank to the payees, the foreign exporters. Some authorities go so far as to say that confirmed bank credits cannot be revoked or cancelled when once the exporters have been notified of their issue, and in this country at least, judicial rulings seem to uphold the contention that even if notice of cancellation has been sent and received, a bank is still under the obligation to accept the bills drawn upon it if the exporter elects still to draw.

\section{Unconfirmed Banker's Credit.}

In contradistinction to a confirmed banker's credit, we have what is known as an unconfirmed banker's credit. a term which hardly merits the inclusion of the word "banker's" in it, for in many cases the banker is merely the intermediary through whom it is advised. In fact, it is often merely an authorization by the importer to his principal, the exporter, to draw bills on a certain bank, without the previous consent of that bank having been obtained. There are thus two cases in which these so-called credits are issued, and the different circumstances in which they may arise may be summarized as follows.

In the first place A, the British importer, asks one of the London banks, say, the City and Midland, to arrange for the National Bank of India in Calcutta to buy the Indian exporter B's bills drawn on the London City and Midland Bank for account of A. The London City and Midland Bank here sends advice of this to the London office of the National Bank of India, at the same time asking that bank to advise its Calcutta office that it may negotiate B's bills drawn on the London City and Midland Bank, but it should be noted that there is no actual undertaking 
on the part of the City and Midland to accept the bills, although in practice, acceptance is not generally refused. The following specimen will give some idea of the form of such a credit.

Credit No. 69. Blanktown, 26th May, 191..

To A.B.

Somewhere in the East.

By this letter we beg to open with you an Unconfirmed Credit in favour of C.D. \& Co. for an amount of E............ available by drafts drawen at ....... months date or sight, aguinst delivery of the following documents-

Bill of Lading issued "to order" and blank endorsed. Policy of Insurance.

Invoice.

Certificates of Origin.

(Signed) E.F. \& Co.

In the second case, the unconfirmed credit may be advised out without reference to the London City and Midland Bank at all: the importer goes direct to the London office of the National Bank of India, asks the manager there to advise the bank's Calcutta branch to purchase B's bills on the London City and Midland Bank, hoping that he may be able to make the necessary arrangements with the latter bank before the bills, which the National Bank of India will buy from B, arrive. If the London City and Midland Bank refuse to accept the bills, the presenting banker will inform importer $\mathrm{A}$, and $\mathrm{A}$ then goes round to some of the other accepting banks and endeavours to arrange matters with them.

In any case the banker negotiating the bills has the documents of title to the goods against which the bill is drawn, attached to the draft, and these he will not part with until the bill is either accepted or paid.

It will be seen, therefore, that in opening unconfirmed credits one is given to understand that a bank may, and will accept the bills if in order, but at the same time no 
definite undertaking to accept is given. Moreover, there seems to be an unwritten law that such credits may be cancelled by the bankers at any time it appears advisable so to do, which may be all right as far as the banker is concerned, seeing that he has never really bound himself to accept the bills. The view taken by the bankers seems to be that morally he is liable, legally he is not, but the writer is of opinion that by causing the credit to be advised to the exporter, the banker does get very near giving an implied warranty to accept the bills. The case of the exporter or manufacturer who has acted on the strength of the advice of the issue of the credit seems to be on a different plane, and there is reason to suppose that if ever cancellation forms the cause for legal action, the decision will be that unconfirmed credits are only subject to revocation to the extent that they shall not have been acted upon when notice of revocation or cancellation is received by the exporter or whoever the user may be.

It may be noted in passing that third parties, that is foreign banks or exchange dealers, purchase bills drawn under confirmed banker's credits on the security of the drawee bank: the credit which the exporter produces when offering bills for sale is proof of his right to draw, and is the agreement of a first-class London banker to accept the bills. With bills drawn on the strength of the issue of an unconfirmed bank credit, the foreign or Colonial banker relies to a certain extent upon the possibility of the London banker's accepting them, but knowing the risks attendant upon the business, he also pays special attention to the standing of the other parties to the transaction-the importer and exporter.

Drawers of bills under these unconfirmed credits have constantly endeavoured to eliminate their responsibility by insisting on the credits being issued "without recourse," the effect of which is that the drawer of the bill, once he has negotiated it through the London bank, or, if abroad, through a foreign bank, has no further 
responsibility on it, and if anything is wrong the banker can only look to the drawee for repayment of his advance. For this reason bankers are very chary about advising credits "without recourse."

\section{Irrevocable Gredit.}

Shippers sometimes protect themselves by insisting on what is termed an irrevocable credit. Cases have come under the writer's notice where a manufacturer or shipper has refused to take orders from abroad, unless he is quite sure of obtaining payment immediately the goods are ready for shipment. With a credit of this nature the exporter is perfectly sure, too, that the opener cannot cancel it until the contract for the sale of the goods it is intended to finance is completed.

\section{Glean Credit.}

The next instrument to be considered is what is called in market jargon, a clean credit. To the uninitiated the name is no clue to the real nature of the credit; the appellation is derived from the fact that bills are drawn under the credit without documents in any shape or form being attached, in other words, absolutely clean. Clean credits are generally opened by firms abroad in favour of shippers or merchants in this country, or, conversely, may be opened by importers in London in favour of foreign exporters, and the procedure followed when opening the credit is this: A B goes to a bank in his own city and informs them of his desire to open a clean credit. The banker then gives him a form to fill up and sign: in it A B states that he wishes the credit to be in favour of $C D$, whom he thereby authorizes to draw bills on him to the extent of so many pounds sterling, at so many days' or months' date or sight, as the case may be, and in consideration of the bank's buying (the banker calls it "negotiating"), C D's drafts, A B engages to accept and pay them at maturity, provided they do not 
exceed in the aggregate the sum named in the credit. The credit is available only for a certain period, usually not exceeding six months, and to preserve his recourse on $\mathrm{A} \mathrm{B}$, the drawee, the banker must not allow $C D$ to draw bills after the date indicated in the credit.

In most cases drafts drawn under clean credits represent bonâ fide shipments, the documents for which have been sent direct to the consignees, but in some instances it is quite manifest that the bills are drawn by persons or firms speculating in exchange, and for this reason banks opening the credits exercise a wide discretion in granting the accommodation. The risks involved are obvious; if for any reason the drawee does not accept or pay the bills in accordance with the undertaking he has signed, there is no security in the shape of documents of title to goods for the bank to fall back upon, and the only remedy is to seek out the drawer of the bills and endeavour to obtain repayment of the amount advanced-often a difficult and unsatisfactory task. Clean credits are, therefore, generally advised by the bankers only for firms of the highest standing, and if a banker has any doubt about the position of the parties to the credit, he insists upon a margin being deposited with him, consisting of actual cash or securities, and he sometimes secures protection by obtaining a suitable guarantee from a third party.

\section{Documentary Gredit.}

Another form of credit which is familiar to most persons dealing in foreign exchange, is that known as a documentary credit, which it will be seen is merely a variation of the unconfirmed credit previously referred to, although in this case it is usually a mercantile firm which accepts the bills; not a bank.

As a rule, a documentary credit is opened at the request of an importer, who approaches the bank, either here or abroad, according to which side is shipping, and having acquainted the bank with his desire to open the credit, 
he is handed a form to fill up and sign. In this form he states that he wishes to open a documentary credit in favour of the foreign exporter, A B, of Blanktown, mentions the total sum for which the credit is to be made available, and states whether one or a series of drafts is to be drawn. He also gives a few particulars of the merchandise to be shipped, and agrees to effect the marine insurance on the goods. In consideration of the bank's agreeing to make advances on the bills which A B may draw on him up to a certain specified amount, he, the importer, engages to accept and pay them at maturity if drawn in accordance with the terms of the credit.

This credit has the two-fold advantage of enabling the exporter to obtain payment for his wares immediately they are ready for shipment, and the foreign importer to obtain delivery of the goods at the port of destination on acceptance or payment of the bill.

Each bill drawn under the credit is accompanied by a full set of shipping documents, usually invoice, bill of lading, and insurance policy, all duly hypothecated to the bank as security for the due payment of the bills, and by examining these documents of title to the goods, the banker is able to see that the conditions of the credit are complied with.

Very often the exporter is allowed to draw for the full value of the goods as invoiced, but if shipments represent speculative merchandise, it is customary to permit only a percentage to be drawn for.

The difference between this credit and a confirmed bank credit is emphasized when it is remembered that the notice of the opening of a documentary credit which is served on the exporter, often contains a clause pointing out that it is not to be considered as a bank credit, and does not relieve the exporter from the liability usually attaching to the drawer of a bill of exchange. Further, that although the credit is to be considered as open for, say, six months (the exact time is specified), it may be cancelled by the 
bank upon giving notice to the parties concerned. The name " documentary credit" would therefore appear to be a misnomer: it is more correct to regard a documentary credit as an authorization by the importer to the banker to make certain advances to the exporter, on the joint responsibility of importer and exporter.

\section{London Acceptance Gredit.}

The exigencies of modern commerce have called into being still another form of credit, a variation of the confirmed banker's credit, which, although not encouraged in some quarters, tends to become more common every day. Where a British exporter is held in high esteem, a foreign branch bank may open what is called a London acceptance credit, which entitles him to draw bills on the London branch of the bank up to a certain limit, previously arranged between the parties.

A credit of this nature is more particularly used where exporters are consigning goods to a foreign branch of their own firm, although it may be, of course, utilized if the goods are consigned for sale to agents.

When a London acceptance credit is opened there will often be no formal document exchanged; the matter is often settled by the exchange of letters. However, as soon as the details of the transaction have been agreed to, the shipper prepares his bill of exchange, attaches the requisite shipping documents, and presents the complete set to the banker. The bill, it should be noted, is drawn at threc or six months' date on the London banker, who, if everything is in order, detaches it from the other documents, accepts it, and returns the bill completed to the drawer, the British exporter. The shipping documents are then forwarded by the banker to his own branch abroad for delivery to the consignees. A small commission is charged for this accommodation, and in reality the trader pledges his goods with the banker, for he signs a letter of hypothecation giving the banker a lien over the shipment, 
and also undertakes that the proceeds of the consignment shall be remitted to London through the foreign branch bank at or before maturity of the bill, upon which the banker has now become liable as acceptor. The completed bill in the hands of the drawer is now a bank acceptance, and as such it can be turned into cash immediately at the best rates on the London discount market.

The shipper does not always draw for the full value of the shipment, as the banker will sometimes accept for only 75 per cent. of the invoice value, but in all cases the banker's accepting bills under these credits is considered as an advance on the security of the whole of the shipment. Moreover, he does not lose his recourse on the drawer by the mere fact of his delivering the produce to the foreign consignees, since in the Letter of Hypothecation the exporter signs in London, he specially undertakes that when the documents of title to the goods are delivered to the consignees, the latter are to hold them until realization, and the proceeds of sale after realization, in trust on behalf of the banker. A further point to be noticed is, that if for any reason sufficient funds should not be forthcoming to repay the banker for the amount of his advance, as represented by the bill or bills he has accepted and will have to pay at due date, then the exporter engages to make up the deficiency forthwith.

The comparative economy of the various methods employed in financing foreign trade by means of the various credits we have described, will be further explained when we come to examine the actual bills drawn.

\section{Revolving Gredit.}

$\Gamma$ In conclusion, it may be stated that most of the credits which are opened for the purpose of enabling exporters to obtain payment for goods as and when ready for shipment, can be made into revolving credits, and in order to dispel the misunderstanding which often exists as to the exact nature of revolving credits, some explanation is necessary. 
There are really three forms of revolving credit, and the first and most familiar form is one which permits the exporter to draw drafts up to, say, $£ 1,000$ outstanding at any one time: the bills, of course, will be drawn at various intervals, as the goods become ready for shipment. In due course the $£ 1,000$ limit is reached, but as soon as sufficient time has elapsed for the first bill to be paid, or for advice of payment to reach home, whichever may be arranged, the credit becomes automatically reavailable until the actual amount outstanding again reaches $€ 1,000$.

The second form of revolving credit is one which enables the accredited person to draw, say, $£ 500$ at any one time in one draft. When that bill has matured and been paid, he is at liberty to draw a further $£ 500$.

In the third case, the revolving credit is opened for, say, $£ 500$, and as soon as that amount is drawn the credit is again available for the original amount. In point of fact this last form is practically a credit for an unlimited amount but with this restriction, that the sum for which the credit is opened must be drawn in a single bill.

The benefits conferred upon the trading and mercantile community by the issue of commercial letters of credit will now be patent to the reader. As far as the exporters are concerned, as soon as their goods are ready for shipment they are given the power to draw bills for the cost of their commodities, and the banker pays the whole sum due, or a large proportion of it, without its being incumbent upon the exporter to wait for the return of his money. $\mathrm{He}$ is practically saved interest on his money for the lengthy period which must elapse between the dispatch and receipt of the goods abroad, plus the time the bills drawn have to run after acceptance by the foreign drawee. A manufacturer or merchant is thus able to turn his money over much quicker than would otherwise be the case, and this economy of time and money not only lowers the cost of production, but facilitates further production. 
The importers in their turn have the advantage of being able to deal with the goods some time before it is necessary to pay for them, and the period between their acceptance of bills and payment is in most cases sufficient for them to realize the merchandise and have the proceeds in hand ready to pay the bills at due date, without its being necessary for them to touch a penny of their own capital. 


\title{
CHAPTER XVI
}

\author{
BILLS DRAWN UNDER VARIOUS CREDITS. SHIPPING \\ DOCUMENTS ATTACHED TO FOREIGN BILLS. BANKER'S \\ SECURITY WHERE DOCUMENTARY BILLS ARE \\ NEGOTIATED. CURRENCY BILLS
}

THE demand bills to which travelling letters of credit give rise call for no further comment, beyond the fact that they are one of the constituents of that great mass of foreign bills which constantly exercises an influence on the exchanges.

\section{Bills drawn under Confirmed Banker's Gredit.}

To arrive at a correct understanding of the bills drawn under the confirmed banker's credit we will trace a supposed transaction. A in Spain is an importer of hides, $\mathrm{B}$ is the exporter in Calcutta. The operation will be financed in the following way: $\mathrm{A}$ in Spain would request his bankers, the Bank of Spain, to instruct their correspondents in London, say, Lloyds Bank, to issue a confirmed credit in favour of $B$, and the credit is drawn up and forwarded to $\mathrm{B}$. When $\mathrm{B}$ has the hides ready for shipment, he draws his draft, say, at sixty or ninety days' sight on Lloyds Bank, London, for the invoice cost, takes it, together with the complete shipping documents, to a local banker in Calcutta, say, the National Bank of India, who, after proper examination, will purchase the bill and cndorse the amount on the letter of credit, which is then returned to $B$ for future use. The bill of exchange and the shipping documents are then sent to London by 
the National Bank of India for presentation to Lloyds Bank, who in due course will accept the bill for account of the Spanish Bank and receive the shipping documents, which will subsequently be forwarded to Spain. The bill itself will be retained in London, and will probably be sold on the discount market by the National Bank.

The Bank of Spain, or its agents, will care for the shipment when it arrives, or will arrange that A takes delivery of the hides under certain agreed conditions, payment finally being made to the bank in one or other of the methods described in the preceding chapter.

We might have chosen a direct operation between Great Britain and India, but our object in giving this threecornered transaction as an example was to emphasize the fact that the bills are often drawn on London for shipments which do not enter this country at all.

One other point calls for attention in regard to the bills drawn under confirmed bank credits; as they are drawn on first-class London bankers, there is not the slightest difficulty in disposing of them, and immediately the letter of credit is produced, foreign bankers and exchange dealers will be glad to purchase the bills, as they know that the risk is practically infinitesimal. That is really the raison d'être of a banker's credit. Bills drawn on foreign importers, of whom the bank to which they are offered for sale knows nothing, would receive scant attention, and the most the banker would offer to do would be to send them for collection; but with the name of a first-class London bank or accepting house on the bills as drawee, the whole aspect of the transaction is altered, and the seller is able to exact the finest rates from bankers purchasing the paper.

Bills under unconfirmed banker's credits were discussed at some length in the last chapter; it only remains to add that although readily negotiable, they do not command quite such good rates as those drawn against confirmed banker's credits, 
We mentioned the case in which bills drawn on a London banker against unconfirmed credits without previous arrangement might be refused acceptance. The reasons for the banker's refusing to lend his name to the bills are diverse, but generally it will be found on investigation that, having already accepted other bills for the clients, the banker considers the amount for which he is liable as acceptor is sufficient in view of the customer's financial responsibility. He therefore declines to add to the risk until some of the bills have been provided for. In such circumstances it is incumbent upon the importer to get some other bank to accept the bills drawn, and the London office of the foreign or colonial bank holding the bills may subsequently be asked to present the bills for acceptance elsewhere. As an alternative, if the importer can get no other bank to accept for him, he will have to provide the necessary funds to take up the bill and so procure the documents for the goods he is anxious to obtain.

We might mention here, what ought perhaps to have been emphasized earlier, that in most cases where a banker agrees to accept bills for a client, he obtains some satisfactory written undertaking from that client to provide funds to pay the bills by the time they arrive at maturity.

\section{Bills under Glean Gredit.}

Bills drawn under clean credits are in some respects unsatisfactory documents to deal with, since in the event of anything happening to the parties operating, there is no collateral security upon which the banker or his agents can foreclose. The reason given by most exporters who do adopt this method of finance is, that by sending the shipping documents for their produce direct to the consignees much time and trouble is saved, and the importer is often placed in the position to deal with the goods long before the bills arrive if passed through the bank. The custom in some trades of selling commodities forward is presumably what is referred to, as in the ordinary course, 
bills and documents sent by mail often arrive before the steamer carrying the goods, in which case there would appear to be no object in sending the documents in advance to the consignee. However, the point is that such bills are drawn, and as we mentioned, they are often taken from first-class firms of high financial responsibility. Where a clean credit is opened, all the exporter has to do is to present his bill to the bank, generally in duplicate, and if properly drawn, the banker buys the bill and sends it to his foreign branch, agent, or correspondent, who presents it for acceptance and at maturity remits the proceeds to the banker who had purchased it from the exporter in London, or abroad, as the case may be.

\section{Bills under Documentary Gredit.}

Bills drawn under documentary credits form one of the principal items in a foreign exchange banker's business, and the paper is known by various names; documentary bills, documentary paper and hypothecation paper, all refer to the same class of bill. These bills are drawn by the exporter on the importer, and it is necessary in all cases for the former to have the shipping documents relating to his goods to attach to his bills. They must be sent in to the banker in complete sets; besides the bills of exchange in duplicate or triplicate, there will be the bills of lading, marine insurance policy, certified invoice, and in many cases a certificate of origin or consular certificate is required, also in duplicate or triplicate. With these documents in his possession it is then time for the exporter to present the bills to the bank for sale. After examination of all the documents, if everything is in order, the banker will pay the drawer the agreed amount and will then remit the bills and shipping documents to their destination.

It depends on the terms of the credit whether or not the shipping documents are delivered to the drawee against acceptance or against payment. If it is intended that they shall be handed over on acceptance of the bill, there 
will be a statement to that effect in the documentary credit ; in the absence of such a clause, it is always understood that the banker must hold the documents, and, for the time being, the goods, until the drawee pays the bill. As a rule, the clause, "Documents on Payment," does not appear in the credit.

Now let us examine a few of the essential points in the documents which accompany these bills.

The bill of lading, being the actual document of title to the goods, is the most important, so we will take that first.

Most bankers negotiating documentary bills insist that the complete set of bills of lading which accompanies these drafts must be made out " to order," and blank endorsed. A blank endorsement, as the reader is probably aware, is formed by the person in whose favour the bill of lading is made out endorsing his name on the instrument: thus,

the bill of lading is to the order of John Jones, he simply writes on the back "John Jones." The effect of such an endorsement is to make the goods deliverable to the holder. and as long as the bank or its agents retain possession of the bills of lading, their title to the merchandise is unimpeachable. It is obvious that a bill of lading to the order of the consignees would defeat the bank's claim to the goods until the consignee had endorsed the bills of lading; consequently, in such a form they should not be accepted. ${ }^{1}$

It is customary also to require the bills of lading to be marked by the shipping company "Freight Paid," otherwise the bank purchasing the drafts to which these are attached, might find itself mulcted in heavy charges, which would considerably detract from the value of the security they hold. In some cases the freight receipt is attached. Too much care cannot be taken in regard to

1 " Chapter 31, Sub-section 4 of the Customs (War Powers) Act, 1915, now makes it obligatory in certain cases for the exporters to insert the names of consignees in bills of lading. To meet the requirements of the Act, and also those of the negotiating banks. the bills of lading are therefore being made out in the following form: 'Shipped minto A B (the consignee) at the order of C D (the shipper).' C D endorses the bill of lading and the bank's security is intact." 
bills of lading, especially where the freight is concerned. As is well known, the captain has a lien over all the cargo for his freight, and if this is not paid when the ship arrives at its destination, the bank negotiating the bill may be faced with serious loss. The goods will not be held over indefinitely awaiting the settlement of the dispute between the consignee and the bank, but will promptly be placed in the care of the port authorities by the captain, and should the banker find it necessary eventually to take charge of the goods, he will be saddled with other heavy expenses besides the freight, all of which he may have difficulty in recovering. Incidentally, it may be pointed out that care should be taken to see that all copies of the bill of lading come into the possession of the banker who purchases the bill of exchange, for the reason that as one copy has no priority over the other, delivery is made to the person who first presents a duly authenticated copy.

When a bill of exchange having the relative documents attached, is presented for acceptance, the drawee has no property in such documents until he either accepts or pays the bill, and the Sale of Goods Act specially recognizes the importance of the bill of lading in this connexion. Section 19, Sub-section 3, definitely enacts that the person to whom one of these bills of exchange is sent cannot retain the bill of lading unless he honours the bill, that is, either pays or accepts it on the spot. ${ }^{1}$

The marine insurance policies, or certificates for insurance which accompany the draft, should be in favour of the bank, or if drawn out in favour of the drawers, then blank endorsed by them. The reason for this proviso is to ensure the value of the shipment being paid to the bank in the event of loss: the bank, or the person to whom it

1 The following is the actual wording of the sub-section in question-

"Where the seller of goods draws on the buyer for the price, and transmits the bill of exchange and bill of lading to the buyer together, to secure acceptance or payment of the l,ill of exchange, the buyer is bound to return the bill of lading if he does not honour the bill of exchange, and if he wrongfully retains the bill of lading the property in the goods does not pass to him." 
has transferred the policies, would claim on the insurance company.

Certificates of insurance are those declarations which represent part only of the sum insured under a larger policy. Where a number of shipments are made it is usual to have one general policy, called an open or floating policy, under which declarations for the various consignments can be made from time to time. The insurance companies in such cases grant separate certificates for each shipment, and as the risks they purport to cover should conform to those set forth in the floating policy, it is wise for the banker to have the terms and conditions of the latter document (including the total amount covered) confirmed to him by the insurance company.

Reference should be made to the shipper's invoice to see that the goods invoiced are not of a lower value than the amount represented by the bills of exchange. Merchandise of a speculative nature is generally avoided by bankers.

Certificates of origin or consular certificates depend upon the Customs' regulations and requirements of the various ports in the countries to which the goods are shipped, and it is impossible to indicate any hard and fast rules concerning such documents: the banker negotiating the bills is expected to acquaint himself with the conditions before operating.

There is one other document which bankers require persons from whom they purchase these documentary bills to sign ; it is called a letter of hypothecation. At one time it was customary to insist upon a letter of hypothecation's accompanying each set of bills drawn under a documentary credit, but in order to facilitate business this rule has of late years been relaxed, and it is now usual to obtain a general letter of hypothecation covering all the bills which may from time to time be purchased from the exporters.

The terms of this general letter of hypothecation are fairly comprehensive, and give the banker full power to 
deal with the relative collateral security at the port of destination. He is empowered, if circumstances render it necessary, to insure the goods against both fire and sea risk, store them, and take all such care of the goods as he would if they were his own property, all, be it understood, at the expense of the drawer of the bill. Provision is also made to cover cases where conditional acceptance is taken. Finally, if the freight remain unpaid, or if the acceptor of the bill default, the banker is authorized to sell all or such part of the goods as may be necessary to liquidate the amount he has advanced, and if the proceeds of sale be insufficient to pay the amount of the bill or bills, he has the power to draw for the deficiency on the persons who signed the general letter of hypothecation. It will be realized, therefore, that the banker seeks to protect himself to the utmost; yet in spite of all these precautions losses are made, especially where the parties concerned become insolvent and the goods do not realize the amount for which the bills have been drawn.

\section{Bills under London Acceptance Credits.}

Now we come to the bills drawn under the London acceptance credits. In this instance, the bill is not sent out of the country, but is accepted in London by the banker who has opened the credit: with the documentary credit the bill is drawn on the importer abroad and accepted by him when presented there by the banker, who then retains it until date of maturity or else gets it discounted on the market. The bill accepted by the banker under the London acceptance credit is returned to the drawer, who, of course, promptly turns it into cash in England.

There is no difference in the actual shipping documents which form the basis for the drawing of a bill under the London acceptance credit ; they are similar in all respects to those which accompany a bill drawn under a documentary credit, but it should be noticed that a letter of hypothecation is required for eacl shipment financed 
through the bank in London: a general letter of hypothecation covering a series of shipments is not usually taken in the case of the London accepting credit. It must also be remembered that where the bills are negotiated under a documentary credit, the proceeds of the bills are under the control of and actually obtained by the banker or his agent; consequently he is able to secure the exchange profit on the homeward remittances. It is not so with the London acceptances. Although the goods are more or less under the control of the banker, and the consignees are said to hold the proceeds of sales in trust on behalf of the banker, it by no means follows that the banker ever secures control of the funds, although in theory he is supposed to do so. All the consignee is bound to do is to see that the remittances are sent home to London in time to reimburse the banker for the amount of the bill he has accepted and will have to pay at due date. For this purpose the consignee is bound in most cases to remit the amount by telegraphic transfers or approved bank bills of exchange on London, and these he may purchase abroad where he likes; the business generally goes to the exchange banker quoting the finest rates for making the remittance. Although the accepting banker in London tries to stipulate when making the contract that the resulting exchange shall be passed through his foreign branch if rates are equal to those quoted by his competitors, it frequently happens that the remittance even then is made through other channels.

Sometimes, however, the banker is able to obtain control of the counter remittance. He gets the exporter to draw two bills : the first will be the bill which is drawn on and accepted by the banker in London; the other is drawn by the exporter on the importer, and is attached to the shipping documents. It is sent out through the bank for collection, and the proceeds are eventually used by the bank in retirement of the bill it has previously accepted.

The various methods just described are those in force 
with the foreign and Colonial branch banks in London, but the practice adopted by the London joint stock banks who accept bills in London for their clients is very similar. In the case of a London bank with no foreign branches, however, the only thing to be done is to send the documents to the foreign centre through one or other of the foreign banks established in London. If two bills are drawn, the procedure will be simple, for the foreign banker will merely collect the one attached to the documents for account of the London bank and remit the proceeds in due course. Where documents are sent forward without a bill, the instructions to be followed by the foreign bank will be embodied in a letter, and in this latter case there is obviously not the same control over the collateral security as there is where a second bill is drawn and sent for collection.

A practice to be condemned is that by which some London banks finance their clients' foreign shipments by accepting bills in London, and then allowing the exporters themselves to send the shipping documents forward to the consignees. By losing control of those documents the banker has absolutely no security for the payment of the bills he has accepted, and if funds are not forthcoming at maturity, the banker will have to pay the bills himself.

\section{Gurrency Bills.}

All the bills we have referred to in this chapter are understood to be in sterling. Currency bills come under a different category. They are both purchased and sent for collection by the bankers. If sent for collection, the drawer awaits advice of payment from the banker, who will ultimately remit him the proceeds. The currency bills the banker purchases outright are taken on the joint security of the drawer, drawee, and endorsers, if any, and the banker will pay due regard to the financial standing of all parties: they are all jointly and severally liable on the bill until payment has been made to the banker. 


\section{CHAPTER XVII}

METHODS BY WHICH EXPORTERS OBTAIN PAYMENT FOP.

THEIR PRODUCE. PARTIAL DELIVERIES; MARGINAL DEPOSIT RECEIPTS AND TRUST RECEIPTS. BILLS

ON THI: FAR EASTERN COUNTRIES

RICHES, it is said, are like sea-water : the more you drink the thirstier you become. We may with reason apply the simile to the exporter, for the greater the credit facilities he gets from the banker, the more eager will he become to find a cheaper way to finance his produce: it matters not what credit system the banks evolve, the trader will always be ready to offer suggestions for a more economical way of carrying out the bankers' proposals. The outcome of all this bargaining is that the large firms are able to get their business done at the very lowest rates, while the smaller houses have to be content with less advantageous terms: the smallness of the exchange banker's profit in the one case is offset by the magnitude of the operations he puts through, and in the other he looks upon the higher return as a compensation or insurance for the greater risks he runs. Financial standing and responsibility count for everything. We have seen how the transactions in a general way are carried out, and we may now proceed to examine more closely the various methods by which the exporters to the more important countries seek to obtain payment for their commodities at a minimum cost to themselves.

\section{Opinion Lists and Credit Lists.}

It is apparent that this bill finance is a business which requires expert and extensive knowledge, not only of money-changing, but also of men and things. The foreign banker, or for that matter, any other banker who does exchange business, is bound to keep at his finger-ends the 
standing and morale of every firm for whom he accepts bills, or to whom he makes cash advances on the security of bills of exchange, and this necessitates the keeping of special books, called "Opinion Lists," which form, so to speak, the financial history of his clients. In the old days such confidential records giving the financial position of the various firms were never kept in written form; each exchange broker or banker preferred to rely solely upon such facts as he could keep in his own mind. The system did not exactly cause chaos, but it led to trouble when the man whose sound knowledge of the parties to bills of exchange happened to be away from the office, and in the event of his retirement or death, his successor usually experienced difficulty in picking up the threads of this very essential part of the business. In the course of time, therefore, most banks and finance houses found it expedient to start these special reference books, and the practice is now a very general one. They do not replace the wellknown credit lists, such as "Seyd's," or " Bradstreet's Ratings," but are supplementary to those useful compendia of commercial information. Each banker gets to know what reliance may be placed on his own clients, and a comparison of notes between the banks enables each one to make a clear estimate of the amount of accommodation which can safely be given to exporters and importers. In the bankers' opinion lists each customer is accorded a certain classification, or credit worth, and the banker is guided by these details when dealing with the sellers of foreign bills. Naturally, the financial standing of a merchant governs to a large extent the credit facilities he enjoys, and when he applies to a banker to finance his shipments, or to buy his bills, the relative soundness of his position not only influences the rates of exchange at which his bills will be bought, but also governs the total amount which the banker will buy or accept. The position of the drawee also must be taken into account. When the drawers of a bill of exchange are financially strong, 
and the drawees prompt in settling their engagements, the banker will pay more for the bills than he would where the parties are comparatively weak.

These, then, are a few of the reasons which prompt the bankers to keep properly chronicled, up-to-date information as to all persons who may be expected to come to them for accommodation, and bearing these points in mind, we may continue our investigation into the methods of finance peculiar to the different classes connected with the export trade.

\section{Financing Outward Shipments.}

London Bankers' Acceptances. There has been a marked tendency of late years to finance outward shipments by means of London bankers' acceptances, and the reasons the exporters prefer this method to the more direct plan of drawing bills on the importers are soon explained: in a word, it is cheaper. When the London banker accepts a bill, the merchant or exporter can sell it under discount forthwith and so receive his money for the shipment; he wants liquid capital in his business, and consequently cannot afford to keep the bill until maturity, since by so doing he would defeat the whole object of the operation, which is saving of interest. If he sends a documentary bill for collection he must wait until the bill has arrived at its due date abroad before he can hope to receive the amount due to him, but a banker's acceptance, if he can get it, obviates that delay. Even where the banker makes an advance on documentary bills, it often suits the exporter better if he can prevail upon the banker to accept bills in London. It is, of course, the saving of interest which really makes the business attractive, and it follows that financing by means of bankers' acceptances will be resorted to only when money is cheap on the London market. For example, if a merchant can get a four months' banker's acceptance discounted in London for about 2 per cent., that will be much cleaper finance than drawing a bill on 
the importer at three months' sight, as in the latter case the exporter will be out of his money during the time the bill is on the water, plus the period it will be running after acceptance, to say nothing of the exchange charged and the bankers' commission. These charges are also a factor to be reckoned with in the case of sterling bills against which the banker makes an advance under a documentary credit.

The most striking instance of the comparative economy of the two methods is to be found in the case of shipments to India, China, and the East. Documentary bills upon which the bankers make advances in London contain a clause to the effect that they are payable at the various banks' buying rate for demand bills on London, plus interest at, say, 6 per cent. from the date of the bill until the approximate date of arrival of the proceeds in London. These are called interest bills, and the following is a specimen of the kind of bill drawn.

EXCHANGE FOR $£^{100 .}$

\section{2, Anchor Street,}

London.

10th June, $191 \ldots$

At sixty days after sight pay this first of exchange (second unpaid) to the order of the Indian Bank, the sum of $f_{100}$ (one hundred pounds sterling) Payable at the Indian Bank's drawing rate for demand bills on London with interest at 6 per cent. per annum added thereto from the date hereof to approximate due date of arrival of the remittance in London-value received. ${ }^{1}$

$$
\text { A. Buggins \& } C o \text {. }
$$

To C. Dollar \& Co.,

Calcutta.

1 The interest clause sometimes reads: "Payable at drawee's option at the A.B. Bank's drawing rate for demand drafts on I.ondon or at their telegraphic transfer rate on London, with interesț." etc., etc, 
A comparison between the charges on one of these bills and those on a banker's acceptance in London, shows the advantages of the one over the other. Take for example a documentary bill bearing the interest clause, drawn on Madras for $£ 500$ at three months' sight. The interest may be calculated approximately for 120 days, which allows for the tenor of the bill and the time taken to get the proceeds back to London. Assuming interest to be at the rate of 6 per cent.

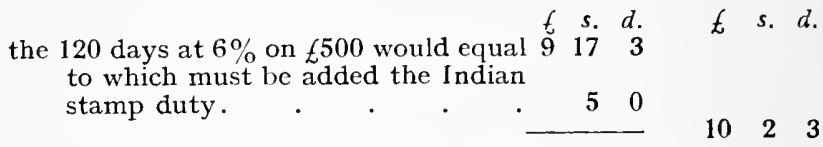

A bill drawn under an acceptance credit on a London bank would be for the same period--

120 days, say, 4 months' sight; the accepting commission may be taken as $1 \frac{1}{2} \%$ per annum$1 \frac{1}{2} \%$ per annum on $£ 500$ for 4 months. Discount on $£ 500$ for 4 months, say, $2 \%$ Stamp duty

$$
\begin{array}{rrr}
f & s . & d . \\
2 & 10 & 0 \\
3 & 6 & 8 \\
& 5 & 0 \\
\hline t^{6} & 1 & 8
\end{array}
$$

This shows plainly how much cheaper the business can be financed by taking a London banker's acceptance. When money is dear, however, and the rate for discounting a four months' sight bill is, say, 4 per cent., firms will revert to interest bills, as there will be no appreciable saving on the acceptance transaction.

As far as the foreign banks are concerned, they, of course, prefer the interest bills, but although there is a higher yield on such paper, we have still to remember that a banker often advances the greater part of the amount represented by a documentary bill, while with an acceptance he advances nothing. His only risk is that proceeds may not be forthcoming at maturity, and it is for this risk he charges the small commission of $1 \frac{1}{2}$ per cent. The commission, small though it is, returns a very satisfactory profit if operations run into large figures, but even taking 
that into consideration, one may still be inclined to ask why it is that the banker is prepared to make himself liable on acceptances for such a trifling commission. We have already shown that a bank's foreign agents are, in most cases, fully empowered to control the collateral security, and as in practice they do keep a sharp eye on the disposal of the merchandise the risk is reduced to a minimum. There is, however, a further point to be considered, which is not present in the ordinary inland billsthe question of exchange. The foreign banker expects to make a profit on the exchange in the currency of the two countries when remittances are sent here to meet bills maturing. If, therefore, the banker does not get a share in the exchange business, the return on the operation hardly seems commensurate with the risk involved, small though it be.

Apart from these soi-disant London acceptances, there are several details which call for attention in the documentary bill business with the East. Bills on Eastern countries are drawn at various usances, from one to six months' sight, and it never seems to be clear to some people why a banker should prefer bills bearing the interest clause to be drawn for short periods only. If, it is argued, a bill is drawn at six months' sight, and it bears 6 per cent. interest from the date of the bill until the counter remittance arrives in London, surely that is better for the banker than if the bill is running for a much shorter time, say, one month. Long dated paper is, however, unsuitable to the exchange banker. Suppose he buys a bill on Shanghai at one month's sight, the bill takes one month on its journey out, and if accepted will be paid in Shanghai two months after leaving London. The funds received from the encashment of the bill at maturity must be remitted by the banker to his client, and this remittance takes, say, another month, which will have to be added to the other period to be charged, thus making three months in all as the time for which interest at 6 per cent. will be added to the amount 
of the original bill drawn from London on Shanghai. The reason the banker would rather take these bills at short usance in preference to the long dated paper is now easily explained: the banker must keep a proportion of his funds liquid for the purpose of purchasing homeward remittances, and if his money were locked up in bills payable six months after sight (eight months in all), there would be a difficulty in meeting demands from those wishing to send money to England. To tie funds up in long usance bills would, in fact, defeat one of the first principles of exchange banking, which is to keep funds liquid. It is also manifest that the exchange profit to be derived from an investment in homeward remittances will generally be greater than the return obtainable if the money is left in six months' interest bills.

Marginal Deposit Receipt. As we have said before, a banker is not always prepared to advance the full amount of the bills. It often happens that exporters to the East, and also the importers upon whom bills are drawn, are not of sufficient standing to merit extensive credit facilities, and although bankers are willing to negotiate a fair amount of the exporter's bills, in the case we are considering they usually endeavour to limit their risk by retaining a margin on each bill negotiated. Suppose the drawer offers a bill for $£ 100$, the banker will advance 75 per cent. and issue a marginal deposit receipt for the remaining 25 per cent., and a similar deduction will be made from each bill passed through the bank. Interest, at an agreed rate, is allowed on these margins from the time the bills are received by the bank until the net proceeds are remitted from abroad, and then, if all bills running are duly honoured and there is no deficiency, the full amount of the margin, plus interest, will be paid over to the client.

Where interest bills are drawn it is customary to allow interest on the marginal deposit at the same rate as that called for in the bills. It would obviously be unfair to collect and retain, say, 6 per cent. on a bill for $£ 100$ from 
the drawee, when only $£^{75}$ had been advanced to the drawer in London, so what the banker really does is to obtain the full interest on the $£ 100$ from the drawee abroad, and then when the proceeds are remitted to England, make over to the drawer the interest on the $£ 25$ which he holds as margin against the payment of the draft.

It is usual to stipulate in the marginal receipts that the deposits are held against " bill or bills running," and in general the amount will not be released until all bills have been met.

On the face of it this system appears to afford sufficient, if not ample security to the bankers who advance against the bills of exchange, but where unscrupulous persons are concerned it is open to abuse. Once an exporter knows the amount which will be advanced against his paper, there is nothing to prevent his invoicing the produce at a price to cover the 25 per cent. margin, and then drawing his bill of exchange in conformity. Unless the banker has an expert knowledge of the commodities shipped, he cannot tell the exact price, and although he advances what purports to be 75 per cent. of the invoice value, it is plain that he is actually paying the exporter the full amount of the bill, as the goods are invoiced at 25 per cent. in excess of their real value. For the successful operation of this malpractice, some collusion between importer and exporter is probably necessary, though it by no means follows that the importer is always a party to the deception, which sooner or later is bound to come to light.

Bills for Collection. In the case of bills, documentary or clean, sent for collection, there is no risk to the banker. He merely sends the paper forward to his Eastern branches and follows the instructions given in the letter which accompanies the documents when delivered to him in London by the drawer; if the documents are to be handed over to the Eastern importer against acceptance, he will pass them on to the drawee when the bill is completed, but if his instructions are, not to part with them until 
payment is made, the bill is simply presented for acceptance, and if not then paid, is held attached to the documents until it suits the importer to take them up. In the meantime the goods will be warehoused, and when the importer eventually retires the bill and takes delivery, the proceeds will be remitted to London, either by mail or by telegraphic transfer, at the option of the drawer of the bill, and finally paid to him less the banker's commission and charges. If the exporter's instructions are, " all charges to be paid by the drawee," the banker will collect them at the time the bill is paid in the East, and in that case the exporter will receive the net amount for which his bill is drawn.

In connexion with the documentary bills drawn under the various forms of credit we have previously discussed, there are one or two customs which seem to be entirely for the benefit of the importer, and it is as well to mention them here.

Documents on Payment. We will take first the case of a bill drawn on an importer for, say, $£ 300$, at three months' date, marked " documents on payment." If on presentation the importer is not in a position to pay the bill, he merely accepts it and returns it to the banker. What the banker then does is to warehouse the goods either in his own warehouse, or in some neutral storage place, and here they are supposed to remain until the bill is paid. In the East, however, and often elsewhere, it is customary to allow the importer to take delivery of a portion of the goods against part payment of the bill : these partial deliveries continue until he has sold the whole shipment, and when the last portion is taken away the banker is supposed to have received the total amount due on the bill.

This practice might be very simple and satisfactory if only one bill were drawn, but where, as is frequently the case, a number of drafts are running and a large amount of produce is in the hands of the banker, the danger is that the acceptor of the bills may pay for and take delivery 
of those goods which command a ready market. If allowed to do this, he sometimes retires the bill drawn against the particular consignment of which he wishes to obtain possession; at other times the proceeds of sales will be placed against the first bill maturing, and as a result the banker may finally find himself left with a depreciated and inadequate security, which by no means represents the value of the bills of exchange he has still on his hands. The confusion becomes worse confounded if the respective shipments are not kept strictly separate, as there will be a tendency for partial deliveries to be taken of a number of consignments, and no matter whether the first or last bill be retired, the bank will eventually be left with a conglomeration of merchandise of doubtful marketable value.

No matter how careful the banker or his agents are, they cannot always tell whether the importer is taking out goods in proportion to the payment he makes. For example, a bill might be drawn for $£ 500$ against 100 cases of goods; if the banker is asked to deliver fifty cases and receives payment of half the amount of the bill, $£ 250$, it is possible for the importer to take cases, the contents of which are worth $£ 350$, and leave the banker with the remaining fifty cases, which, although they are supposed to be security for the balance of the bill, are in reality worth only $£ 150$.

There is then the case where the banker delivers the complete set of shipping documents on acceptance of the bill by the importer: here he undoubtedly parts with the whole of his collateral security, and, apart from the safeguard which the several letters of hypothecation we have mentioned are to him, the banker's only means of protection is to obtain from the importer a trust receipt. The mere mention of this document is a reminder that it is one of the instruments used in foreign exchange banking which ought to be thoroughly explained to the reader. 
TRUST Receipts. Shorn of all its technicalities, the trust receipt is simply an undertaking which the acceptor of a "Documents on Payment" bill in a foreign port signs in order to obtain delivery of the goods before he has paid the bill. He recognizes the bank's lien on the merchandise, and undertakes to sell it and to pay the proceeds into the bank as soon as received.

In many cases the drawees are permitted to store the collateral security in their own warehouses, but in some places the banks have their own storage accommodation (go-downs, they are called in the East), which enables them to exercise some sort of a check on the deliveries.

The custom of delivering goods under trust receipt seems to have-originated in America, where the law recognizes to a far greater extent than elsewhere the bank's property, in the goods after they are given up to the acceptor of a bill. As a matter of fact, a drawer of a bill from this side will rarely authorize delivery under trust receipt, and the banks abroad more often than not take the responsibility themselves, which means in effect that they part with the goods contrary to the instructions of the drawer, to whom they are then, of course, responsible for the ultimate payment of the bill representing the value of the shipment. The whole thing in principle amounts to this: the difference between having a fivepound note in your pocket and another man's owing it to you; and although the system is good enough where the acceptor is perfectly trustworthy, yet, so long as human nature is what it is, difficulties will always arise, and from the standpoint of British banking we have no hesitation in saying that trust receipt facilities are open to grave objection.

The fact remains, however, that with bankers abroad the trust receipt is a pis aller. It frequently happens at a foreign port that there is no public storage accommodation, and if the bank does not possess its own warehouses it is practically obliged to deliver the merchandise to the 
acceptor of the bill against his signature to a trust receipt. Even where public warehouses or go-downs do exist, the system of storing the collateral security in them is not liked, since in many places there is nothing to prevent one dealer's inspecting the other person's property and so getting a clue to the quality of produce shipped and the source of supply. However, as we have pointed out, the banks do sometimes surmount this difficulty by building or leasing their own warehouses, and if they desire to avoid the disputes which occasionally arise when trust receipt facilities are given, the remedy is obvious.

There is this much to be said for the system, it enables the importers to deal with merchandise immediately it arrives; sometimes, too, the bank does not run great risk, as the importer has frequently sold the goods against payment on delivery. In this case he will give the bank details of his sale and will sign a trust receipt agreeing to collect the proceeds from his buyer and pay them over to the bank immediately. But if the merchandise is not sold and the banker allows it to be stored in the importer's own warehouse in exchange for a signed trust receipt, he is in a similar position to a person walking through a great wood: the walker cannot see the leaves of the trees, and the banker cannot see the goods over which he ought to have control, consequently the importer is at liberty to deliver how, when and where he likes. To guard against this contingency some bankers only deliver the relative documents against trust receipts to enable the importer to store the commodities in a neutral warehouse in the bank's name. The receipt, which the owners of the store issue, is held by the bankers, and subsequent deliveries can then only be made under the cognizance of the bank.

The financial responsibility of the importer is the factor which counts in all trust receipt facilities, and unless the banker has confidence in the position of the importer the accommodation cannot safely be given.

The several practices we have just enunciated are in 
operation in many countries besides those Eastern centres we have indicated. The trust receipt system, for example, is said to have been evolved in the United States, but something akin to it is seen in the cotton and woollen manufacturing districts of England, where it is no uncommon thing for the raw material to be delivered on the signature of a trust document before the bills of exchange are paid. As one of the bankers remarked to the writer, it would be a clever banker who could pick out his own security once the shipment had reached the mills of the manufacturers.

Needless to say, there is always a vast quantity of merchandise also stored in the London dock warehouses, and the same difficulties which arise abroad occasionally present themselves here. Bills of exchange drawn on London importers are constantly arriving from foreign countries, and if the banker is instructed not to deliver documents except on payment, he will have to take delivery of the goods and warehouse them until the drawee is in a position to pay the accepted bill. If the importer who has accepted a "documents on payment" bill, desires to obtain possession of the merchandise before maturity of the instrument, he can, of course, do so by paying the bill, and in that case the banker will allow him 1 ebate on the amount of the bill for the unexpired period at $\frac{1}{2}$ per cent. above the London joint stock banks' rate of interest for short deposits.

Partial Deliveries. Partial deliveries, except in rare instances, are not made in London, but some bankers do permit the importer to have the documents of title to the goods on the deposit of satisfactory security or against the guarantee of other parties of repute. However convenient this system may be to the importer, it cannot be regarded as suitable to the exchange banker, who, by his own act, ties up funds which could have been utilized to better advantage in financing any outward business offering. It is plain that as long as the banker holds the accepted bill with documents attached, there is some 
incentive for the importer to make early payment in order to be able to deal with the shipment, but once you let him obtain possession of the documents against the deposit of security, the incentive to take up his bill is gone, and the chances are that he will make no effort to pay it until the date of maturity ; the banker will thus be out of his money during the whole time the bill is running, for, as we shall see later on, these "Documents on Payment" bills are not usually discountable. 


\section{CHAPTER XVIII}

DOCUMENTARY BILLS ON AUSTRALIA, EGYPT, SOUTH AFRICA, THE UNITED STATES OF AMERICA, AND OTHER COUNTRIES

Wirhin the limits of this volume it is obviously impossible to describe the bills drawn on every country, but it will be sufficient for all practical purposes if we confine our attention to the paper current between London and some of the more important foreign and colonial centres. We have seen how business is transacted with the East; let us here extend our operations to the Australian continent.

\section{Australasia.}

The customary usance for bills between Great Britain and Australasia is sixty days' sight, but the currency of the numerous drafts drawn varies from sight up to 120 days' sight.

Bills are not drawn payable with interest, as is the case with drafts on the Far East. When there is any difference in exchange, it is, by arrangement between the shippers and importers, sometimes borne by the one, sometimes by the other. In practice the cost of exchange is usually included in the exporter's invoice, and the draft is then drawn for an amount which will yield, after the deduction of the exchange and commission charged by the bank negotiating the bill, the net amount of the attached invoice. Frequently, however, bills are drawn for the amount of the invoice, with the clause added, "payable with exchange per endorsement," the effect of which is, as we mentioned earlier in our investigation, to transfer the onus of fixing the rate of exchange on to the banker. 
Bills are drawn both "documents on payment" and "documents on acceptance," according to the arrangements between the parties to the transaction, but it is the general practice for banks who negotiate bills bearing the latter clause, to retain the right to use their own discretion regarding the surrender of documents: if, on arrival of the goods, the position of the drawee is such that the bank considers it unsafe to deliver the bills of lading, it will safeguard the position of the drawer by insisting on payment before parting with the security.

The principles in regard to homeward remittances for bills drawn under the various credits do not differ materially from those we have described in other cases, but there seems to be some difference of opinion as to the correct procedure to be followed when making counter remittances for bills which the exporters have sent to Australia for collection through the banks. In some instances, if drafts are sent for collection, and no definite instructions are given in regard to the ultimate payment to be made by the banker to the exporter, it is held that the collecting bank's duty is to remit proceeds by drafts at " usance," say, at sixty days' sight, and we believe it was at one time customary to make the remittances in this way. Of late years, however, we understand it has been the practice for some banks to remit proceeds of bills for collection at " sight," charging, of course, the higher rate of exchange always ruling for sight or demand bills. In the absence of unanimity among bankers, there is little use our discussing the rights and wrongs of the matter; competition will finally decide which procedure is to be followed, and although when it came to discounting the sixty days' sight bill on the London market there would not appear to be much difference in the remittance as far as the exporter is concerned, yet from the point of view of the importer who has to pay the higher exchange for the sight bill in Australia, it would seem more equitable to send the proceeds by sixty days' sight bills. 


\section{Egypt.}

Bills on Egypt are usually drawn in sterling, and the following details may be taken as typical of the general transactions which take place.

First we get bills drawn "payable at par," that is, the par rate is specified in the body of the bill: if no rate at all is mentioned, then the draft is still understood to be payable at par. Such paper is payable in Egypt at Piastres $97 \frac{1}{2}$ per $£ 1$, and the Egyptian banks buy, or advance on the bills at 1 per cent. over Bank Rate, with a minimum of 5 per cent., the loss on exchange, if any, to be borne by the drawee or drawer, according to arrangement.

Bills are also drawn payable at current rate of exchange, plus interest at a specified rate. Here, as in the East, drawees pay the amount of the bill, plus interest at the rate mentioned from date of negotiation to approximate date of arrival of proceeds in London. If exchange is above par the drawee bears the loss, but if it is below par he receives the benefit. The proceeds of such bills are remitted to London at par, plus interest collected.

Egypt is also one of those countries upon which bills are drawn bearing the clause "exchange as per endorsement." Drawees, as in the preceding case, are expected to pay interest, exchange, and other charges, but in view of the exchange clause, they frequently contest their liability for additional interest charged on the bill, and if the banker is unsuccessful in collecting the interest, he eventually claims it from the drawer in England.

Where bills are sent for collection, the drawees, of course, do not pay interest, and any gain or loss in exchange is a matter which concerns the parties to the bill: the banker collects the bill for an agreed commission, and leaves all other questions to be settled between the drawer and the drawee.

\section{South Africa.}

Our survey would not be complete without some reference to South African banking procedure. The exchange 
with the countries within the Union of South Africa and Rhodesia is on a sterling basis, but as with Australia there are certain differences in exchange which have to be taken into account. The price fluctuates and is rarely above par, but it is sometimes at a discount per $£ 100$. Banks quote for bills at sight, thirty days, sixty days and ninety days, but exporters draw at all usances, from demand to 120 days' sight. There appears to be a preference for ninety days' sight bills, which is the most convenient usance for the South African traders, and occasionally even a six months' bill makes its appearance.

Drafts from Great Britain are seldom drawn with the interest clause, although we believe it is the custom to draw such bills from New York on South Africa.

The South African banks negotiate exporters' bills drawn under the various credits we have previously enumerated: they also purchase bills offered purely on the standing of the names appearing on the paper, each bill being judged entirely on its merits. If staple articles of merchandise are shipped, and the drawer and drawee are first-class people, the banker will advance the whole amount of the bill, but if he considers their financial responsibility does not warrant the full extent of the accommodation, or goods of a perishable or speculative nature are being exported, only about 75 per cent. of the amount for which the bill is drawn will be advanced.

It should also be noted in the case of these African bills, that it is the custom for the exporter to include the exchange in his invoice for the shipment, and then draw his bill for the full amount of the invoice.

When bills are sent for collection through the South African banks, sometimes the drawee pays the extra exchange and charges, and on other occasions they are borne by the drawer; it is generally a question which is settled by the importers and exporters themselves, and the banker either collects the amount of his commission, etc., from the drawee, or else deducts it from the remittance which is 
made to the exporter in final settlement of the bills at maturity.

In each class of bill documents are given up on acceptance or payment on the usual conditions.

The proceeds of bills negotiated, or, as some banks call them, bills remitted, are utilized by the banks for the purchase of paper and telegraphic transfers offering in South Africa drawn on London.

As regards bills for collection, the proceeds are remitted home at the current rate for demand bills and/or telegraphic transfers on London, according to the arrangements made between the various operators.

The following details give in a convenient way some idea of the form homeward bills take.

No........ Pretoria, 1st May, 191...

EXCHANGE FOR $£ 200$.

Three months after sight of this first of exchange (second of the same tenor and date being unpaid) pay to the order of the A.B. Bank the sum of $£ 200$ (two hundred pounds sterling) value received, and place the same to account of thirty boxes of ostrich feathers shipped per s.s. "Union Castle" to London.

To Messrs. Blank \& Co., J. C. Kruger \& Co.

Nile Street, London.

\section{U.S.A.}

We now come to the American Continent, and as conditions with the United States are so well-known, little need be said about the practice there. American banks until quite recently were precluded from opening branches in other countries, and in consequence the bill business was almost entirely in the hands of the British and Colonial banks and finance houses. This restriction has, however, now been removed, and we may shortly expect to see 
American banks in active competition with our institutions in London.

The most common usance for bills drawn from Great Britain is sixty days' sight, although ninety days' sight bills are also constantly seen. The principal centre upon which the bills are drawn is New York, and documents are given up both on acceptance and on payment, subject to the conditions we have mentioned with other centres. There is, however, a very large number of bills drawn and negotiated under the several credits mentioned, which never reach the United States: arrangements are made for the issue of the commercial credits from London, and when shipments are sent to the United States from many foreign countries, the relative bills are drawn on and accepted in London by London banks and accepting houses. To these institutions the drafts with shipping documents attached are sent, and if everything is in order, the bills are accepted and retained in London, while the documents are at once sent forward to New York to reliable agents of the London banks. It is then a question whether to deliver them to the American importers on or before payment. Generally speaking, if the bank's correspondents are satisfied as to the financial responsibility of the importers, the documents will be handed over on an undertaking to pay to the bank the proceeds of sales as soon as received. Trust receipt facilities in the United States, we need hardly say, are the rule rather than the exception, and as the trust deliveries are extensively practised, it is often found difficult to discriminate between particular firms.

Bills are, of course, drawn direct, and not infrequently bear the clause " documents on payment," and if a client's instructions to this effect are ignored and documents are delivered on acceptance, the banker practically takes the responsibility on his own shoulders. As a matter of fact, trust receipt facilities have become so much a part and parcel of the American system that it is doubtful whether 
the practice will ever be eradicated. The custom doubtless originated when few bills were drawn on New York: the majority of the drafts for American shipments from all over the world were drawn on London first, owing to the fact that no discount market existed in New York, and, secondly, because the names of American drawees were so little known abroad that even where bills were drawn direct they were hard to negotiate. In these circumstances, the banking authorities in the United States seem to have instituted the trust receipt system to save themselves the trouble of carrying the heterogeneous collection of bills of lading and other documents which were constantly arriving from other centres without bills in any shape or form being attached. At the present time, however, New York is making a most determined attempt to create a discount market there, and has even gone to the length of issuing dollar credits throughout the world in the hope that exporters from other countries may be induced to draw bills in dollars, and so help New York in the course of time to take its place among the other nations as one of the great monetary centres.

The counter remittances to Great Britain are often made by means of sixty days' sight bills, but both demand and telegraphic transfer remittances are largely in evidence.

\section{South America.}

Exporters to South American countries dispose of their bills drawn under credits opened with the London agencies of the various banks on terms similar to those we have discussed as regards other countries. The usance of the drafts varies, but as a rule, they are drawn on the Argentine and Brazil at ninety days' sight, and on Mexico at sixty days' sight. With the latter country three days' sight bills are frequently drawn, too. We may add that thirty days' sight bills are often used with Columbia, and, while the Northern countries of South America draw at the same 
usance as Mexico. Chile, Peru and Bolivia follow the practice of Argentina and Brazil. In all these countries documents are delivered on acceptance or on payment, according to the instructions given by the drawers of the bills, and the comparative financial strength of those whose names are on the bills.

As with the other countries we have examined, the adjustment of any gain or loss in exchange is a matter of arrangement between the exporters and importers. Many merchants, however, when drawing sterling bills on firms in the Argentine and Brazil carefully make the bills payable in one of the well-known centres, and by this means safeguard themselves from the loss in exchange which may be incurred where it is left to the choice of the acceptor to pay a bill in some local town where he is domiciled. This is an important point, especially where both the State and the Capital bear the same name. For instance, it is preferable for bills on places in the State of Buenos Aires to be drawn payable in Buenos Aires, the capital of the Argentine Republic, if it is desired to avoid the wide differences sometimes existing in exchange. Bills on the State of Rio Grande do Sul, Brazil, are best drawn payable at the capital, Port Alegre.

Interest bills are not used in the South American trade. Return remittances are made by long exchange, that is, ninety days' sight bills on London, or by telegraphic transfer. Mexico also makes homeward remittances by means of drafts at three days' sight.

\section{Spain, Italy, France, etc.}

The bills described in this chapter by no means represent the whole of the foreign paper seen on the London market, neither do they account for all the return remittances in the shape of foreign drafts which circulate on the London market; Spain, Italy, France and other European countries all utilize London for financing their import trade, and the credits they open from time to time give rise to a 
good many of the bills found in the portfolios of London bankers. At the time of writing, however, owing to the disorganization caused by the war and the subsequent difficulty of obtaining reimbursement credits in London, documentary demand drafts on rather a large scale are being drawn on the more important trading centres of Italy, Spain and contiguous countries.

\section{Scandinavian Union.}

Countries in the Scandinavian Union, despite their favourable position in regard to trade with the belligerent nations, were also faced with abnormal conditions, and in many cases sterling exchange was either difficult or impossible to obtain. We have not space to describe the state of affairs in each country, but Denmark may be taken as representative of the general conditions prevailing for some months during the war.

In accordance with the Danish law governing bills of exchange, bills drawn in sterling or in other foreign currencies have to be collected at the official rate for the centre concerned, that is at the quotation ruling on the exchange at Copenhagen. The selling rate is the one taken in normal times, but during the Great War the difficulty of obtaining sterling remittance became more and more marked, until the time came when there were no sellers of cheques on London except at a ridiculously high premium. Even where buyers were willing to pay the enhanced prices, drafts for moderate amounts only were obtainable. These conditions were due to the fact that Denmark had many obligations to fulfil in England, partly for fresh imports, and partly for maturing credits and financial drafts, and in spite of the ever increasing exports to Great Britain, sufficient sterling to meet trade requirements was not forthcoming.

In view of the impossibility of sending counter remittances to London in payment of sterling bills collected in Denmark, various measures were advocated, but the system 
adopted by some of the larger Danish banks was, for the proceeds of bills collected to be placed to the credit of an account kept in kroner in Denmark, in the name of the bank which had sent the paper for collection. The credit balances were then at the free disposal of the bank or firm which had sent the bills from London, and the most suitable way for the funds to be utilized was for the creditor to sell in England to banks and others under the obligation to make payments in Denmark, bills drawn in kroner.

The proviso that bills on Denmark cannot be collected at an exchange higher than the official quotation does not prevent bills being drawn with protecting clauses, such as, " payable with cheque on London," " payable at the rate of exchange as per endorsement," etc., and where these or similar clauses are embodied in the bill, the collecting bank can insist on the conditions being fulfilled, independently of the official rates. In such cases, however, persons sending bills containing these conditional clauses would be well-advised to have a previous understanding with the drawees in Denmark, otherwise disputes are sure to arise.

With documentary bills the collecting banker is naturally in the better position, as he can refuse to deliver documents unless payment is made by cheque on London at the agreed rate, but in the absence of special instructions documentary bills, like all other drafts, are always collected at the official rate. 


\section{CHAPTER XIX}

\section{ON FINANCE BILI.S}

IN Chapter VII we discussed one of the most potent influences on the exchanges-finance bills. But, although it was shown that such paper is largely drawn in connexion with arbitrage operations in international stocks and shares, we must not lose sight of the fact that this accommodation paper is constantly in evidence in other transactions. Some confusion seems to exist on the market as to what really constitutes finance paper, but among exchange writers there is a consensus of opinion that the term should be restricted to all long bills drawn by the banks and accepting houses of one country on those of another, bills, that is to say, which are "manufactured" for the express purpose of raising money at an opportune moment. There is no particular magic in the process; all that happens is for the recognized accepting houses of one centre to grant facilities to foreign operators to draw bills on them whenever it is apparent that ready money can be profitably employed on the foreign market. The long, or three months' bill is sometimes drawn against a standing balance with the correspondent, but more often than not the banker abroad is allowed to draw bills on the understanding that he shall put the acceptors in funds before maturity. These bills, bearing the names of first-class banks or finance houses, are readily saleable at the best rates, and immediately they are offered the banker receives funds to indulge in what other operations he likes. In due course the bill arrives, say, in London, is accepted, and then sold under discount on the open market, upon which it will circulate until the date of maturity, and, as we have seen, neither the drawer nor the acceptor need put down a single penny until the time for payment arrives. When the bill does fall due to be paid, the drawer 
must see that funds are in the hands of his friend the acceptor, and it is customary to remit the amount of the bill so that it shall be in the hands of the London acceptor at least one day before the presentation of the finance bill. A sight draft is generally purchased on the foreign market and sent forward for this purpose, and the effect of this sight draft on the exchange between two countries is the reverse to that occasioned by the drawing of the finance bill : the latter would tend to depress the exchange, but the former would elevate it, if one may use such an expression. It is not that the first drawing of these finance bills, or even of the remittance of the sight drafts, has a marked influcnce on the exchange at once, but it seems inseparable from such accommodation that there should be a constant renewal of the facilities. If the three months' bills were merely renewed at maturity, the influence would not be great, but when we see that further bills are drawn the final effect becomes more plain.

This is how the matter works in practice.

We may presume the A B Bank in New York has drawn a ninety days' sight bill on the Blank accepting house in London; towards the end of the period in question the A B Bank perceives that it will be inconvenient to find the wherewithal to purchase the remittance which must shortly be sent forward to London to meet Blank's acceptance, so what it does is to draw yet another bill of the same tenor and sell it on the New York market, and by this means procure sufficient funds to remit in cover of the previous bill drawn.

It may appear at first sight that the creation of these finance bills can go on indefinitely, but that is not so. The amount of paper running on the market for any one bank, finance house or individual, can generally be pretty well gauged, and if at any time the market deems the sum total to be sufficient, there will be a tendency to discriminate against the bills. Takers of bills do not exactly decline to receive more of the paper of the firm in question, but 
higher rates will be charged as an insurance against the extra risk: it is as if the buyers say, "We do not refuse to take more of A B's bills, but we would rather not be asked to receive more," and a continuance of this state of affairs soon causes trouble in the quarters concerned. Consequently, further bills will not be drawn as a rule until a portion of those circulating has run off. In practice operators do not usually go to the extent of drawing more than the foreign discount market will readily absorb without comment-they know that once discounters eye their paper suspiciously, they become, what is termed "talked about," and, as we all know, nothing is more damaging to a financial firm's credit than to be in such a position.

As we have referred to the discount market in passing, it may be well to give the student some idea of the way in which the price of these "long " finance bills is calculated. Briefly stated, it is the market rate of discount ruling in the city upon which the bill is drawn that governs the price. If the reader will refer to Chapter $V$, he will see that the rate at which bank paper is discounted is considerably less than that charged for trade bills, from which it follows that as these finance bills come under the category of bankers' bills, they can be sold, as soon as drawn, subject to the lower charge, namely, the market rate of discount. It is this rate of discount, then, which principally affects the drawing of finance bills; the higher the market discount quotation in London, and the lower the price of money on the foreign market, the fewer such bills will be drawn, and vice versa.

An additional point to be borne in mind is, that there are certain seasons which favour the drawing of these finance bills, as they affect the supply of exchange upon which the drawer is dependent for covering his operations. In the United States, for instance, the exports of cotton, wheat and other grain, are principally made during the autumn, and bills drawn against the cargoes will be offering 
in large quantities at that period of the year ; consequently exchange will be low. The drawers of finance bills on Great Britain know this, and if they were selling such paper, say, in May or June, the possibility of their being able to buy demand exchange at low rates for remittance to London to meet maturing finance bills, will to some extent influence their drawings.

\section{“ Kite-Flyers."}

As against the foregoing, which may be called the more legitimate form of finance bills, we get another variety, dignified by the name of finance bills, it is true, but referred to on the market as "kite-flyers." Kite-flying operations are seen where a firm, not necessarily a financial house, trades on its reputation and induces other people to accept bills, the sale of which is a means of furnishing the drawers with funds. Such bills are accommodation paper, pure and simple, but no one ever realizes that fact until the drawing house signifies its inability to provide the acceptors with the money to meet the bills at maturity.

It is never easy to tell when kite-flying operations are in progress; the bills are often drawn by reputable trading concerns, public companies, and even by foreign banks on banks and finance houses in London, and when a series of renewal bills is drawn the practice may continue unchecked for a long period.

Probably the worst instance of kite-flying in recent years was that which came to light upon the failure of the Bank of Egypt. The investigation undertaken by the liquidator proved conclusively that the bank had been obtaining extensive credits on the London money market simply on its name: it had in fact been living entirely on its credit for a considerable time, and the moment the bank's bills became unsaleable it failed. Whenever liabilities seemed to be pressing, funds were raised by drawing and selling three months' bills against cash in Egypt, and when these 
bills matured, the money to meet them was obtained from further sales of drafts.

\section{" House Paper."}

There is yet another variety of finance bill, which comes under the category of "House Paper." House paper, so called, comprises all those bills drawn by the foreign branch of a firm on its London house, or vice versa, that is, bills bearing identical names as drawers and drawees. Here we must, as it were, separate the dross from the fine paper : we cannot rightly describe a firm's documentary house paper as finance bills, for, although the exchange dealer does not really get the security of two names to his bills, he still has the documents for the merchandise they represent. The risk comes in where a firm draws these bills clean, that is without documents in any shape or form attached: such are finance bills of doubtful value, and when the paper makes its appearance firms are said to be drawing " pig on pork." There would not be much trouble if the circumstances were known to the market, but as it often happens that the two branches of a firm work under different names, it is sometimes extremely difficult to discern which bills come under this appellation. However, the bankers do scrutinize very carefully any paper which is suspected to be pig on pork, and the discovery that a trader is indulging in this method of finance is the signal for the banker to go carefully with him.

\section{Advances for Grop Requirements.}

Finally, we get those bills which are loosely described as finance paper, but which the bankers know all the time to be nothing of the sort: we refer to the bills drawn in connexion with crop requirements. The transactions from which they arise are somewhat involved, but may be roughly divided into two classes. First, there are the bills resulting from " up-country advances." In this case the bankers abroad, having satisfied themselves of the 
respectability, position, etc., of certain merchants, make them advances in order to enable them to purchase crops up country: with these funds the merchants buy the produce from the agriculturalists, and when the arrangements are completed for export they deliver the bills drawn against the shipments to the banker. In the second case, advances are made direct to the farmers for the purpose of moving the crops, and when the grain, or whatever it be, is ready for shipment, the bills naturally go through the banker who has given the accommodation. 


\section{CHAPTER XX}

THE DISCOUNT MARKET. THE BILL-BROKER

We now arrive at the final stage of our enquiry, and having considered the circumstances under which the various bills are brought into being and how they are bought and sold, we may proceed to an examination of the way in which they are discounted. The discount market, we need hardly say, is one of the most interesting and at the same time one of the most important from the exchange banker's point of view: he is bound to watch its movements, and must also be careful to keep himself au fait with all the little changes constantly occurring.

\section{Bill Discounting.}

Let us be sure before we go further that we really know what discounting a bill actually means. Merchants, bankers, commercial men, and even some of the text-books have got into a slovenly and ambiguous way in their employment of the terms "discounting" and "discounted." Some years ago the writer happened to be present at a law lecture given by Sir John Paget, K.C., when attention was called to this very point. The word " discounting," as this eminent legal luminary remarked, is used indiscriminately to describe either the position of the person negotiating a bill for value prior to maturity, the amount the seller of the bill receives being less than the value in proportion to the unexpired term of the bill; or, to designate the position of the party who takes over the bill giving such reduced value to the transferor. In view of this existing ambiguity, it will be well to bear in mind that to discount a bill is to buy it, or, as Sir John Paget says, to become the transferee of it by having it endorsed or transferred by delivery by the holder, for a price settled either by agreement or by the current 
market rate of discount. The discounter, obviously, is the person who buys the bill, while the one who gets the bill discounted, that is, sells it, is the transferor.

Now let us examine the practice on the London market.

In the first place we may say that there is a good deal of discounting done first hand by the joint stock banks, the country banks, and the private banking and financial houses. The gentlemen connected with these concerns are always willing to oblige a good customer by finding him cash when he wants it - at a price. A banker, we have seen it stated, is a man who takes care of other people's money and lets them have it as and when required, that is, if there is no obstacle (e.g., a moratorium) in the way. That, however, is only one side of the picture: the banker is really a distributing agent; he receives a flow of money from the quarters where it cannot be usefully employed, and forthwith proceeds to direct it into other and more profitable channels. It is in this bill finance, or, as some prefer to call it, advances on bills, that part of the capital for which the banker is the custodian, is invested. In fact, it is an important part of the banker's business to lend money in such a manner and on such securities as will enable him promptly to keep the implied promise he has made when receiving the cash, to repay it whenever called upon to do so. These bills which he buys or discounts for his ordinary customers arise more often than not out of the genuine trade transactions, although, of course, it is no uncommon thing for accommodation paper to find its way into the bank's hands. Take the case of the merchant engaged in the internal trade of our country-a timber merchant, for instance, who sells a parcel of timber to his customer in Shoreditch. As the cabinet-maker there who buys the wood cannot get a return on it until he has manufactured various articles of domestic furniture, he will pay the timber merchant with, say, a three or six months' sight acceptance. That is to say, the timber merchant draws a bill on the cabinet-maker, who accepts 
it. At the end of the period the latter expects to have sold his furniture and have the cash in hand to pay the bill. The timber merchant in his turn cannot afford to wait until the maturity of the bill for payment, so he takes it to his banker, say, the London and South Western Bank, and if the acceptor be in good repute, the banker will discount the bill for a small charge, or, in other words, he buys the bill from the timber merchant and keeps it until maturity, when it will be presented to the acceptor for payment. In this case there is no need for the intervention of a bill-broker; the parties concerned carry out their own transaction and no middleman is necessary. As we have mentioned earlier in this book a banker seldom re-discounts these bills: they invariably remain in his portfolio until maturity. He has the drawer's and acceptor's names on the bill, and as long as a watchful eye is kept on the course of the various trades and the standing of the parties concerned, the risk on such paper is more or less nominal. The reason the bankers do not re-discount these bills is, that were they found to be doing so the market would look askance at the operation, and jump to the conclusion that something was wrong with the bank, which would be presumed to be short of funds and not able to pay its way easily. The amount of such paper offering, however, is negligible as compared with other bills. In fact, it represents but a small proportion of the huge volume of bills circulating on the London market. What interest the bankers most of all are the bills which arise from the exporting and importing operations.

\section{The Bill-broker.}

When it comes to discount operations the London banks, as a rule, do not deal direct with the sellers. In the banking world, as in every other progressive commercial community, there exists a class whose function it is to act as middlemen between the producer and the consumer, and the growth of this class has sometimes led critics to 
consider that the profit made by the middleman is an unnecessary charge upon the commodity. The intermediary who has caused all the heart-burning and discussion among bankers is the bill-broker. His operations are constantly under observation, and the system which permits of this middleman's deriving a profit from business which in other countries is in the hands of the banker, has been widely criticized. Bankers and financiers tacitly acquiesce in the presence of the bill-broker on their markets, but when under modern conditions he succeeds in attracting funds which ought to have come their way, they are apt to disclaim against their folly in permitting the birth of a competitor whose like does not exist on the Continental money markets. At first sight it does seem strange that bankers should have allowed this business to pass out of their hands, but we believe that at the outset the profession of bill-broking, if we may use such an ugly word, was brought into being by the failure of the old private bankers to encourage the discount operations of their clients. There was no eagerness to afford cheap credit facilities, and unless the customer was of the highest standing, high rates were exacted. It has been said that the idea of the old private banker was, that if a man had a bill to discount, he should adopt a sufficiently humble demeanour and approach his banker, and the man of pounds, shillings and pence would then be pleased to discount it. The idea that a banker should run about after a man who had a bill, or, as one of the bankers put it, that a large body of accomplished gentlemen should run all over London to find a man who had got a bill in order to compete for the honour of discounting it, never entered into their heads in that charming, good old-fashioned time. Now, it is manifest that that blissful state of affairs is altered, and we find the man with bills of exchange compared with Penelope, pestered with many suitors, while the bill-brokers are the men who run the streets to ferret out the possessors of drafts. It seems, then, that owing to the sins of the 
bankers of bygone days, the commercial men began to look elsewhere for accommodation, and almost imperceptibly there sprang into existence a number of dealers, who were willing to undertake the business at very fine rates. No discount transaction was considered too small, no trouble too great, and these bill-brokers were always ready to avail themselves of a slight profit, either by discounting the bills themselves, or by finding discounters for the paper of respectable merchants and traders.

It is not, however, wise to lay too much stress on the shortcomings of the older generation of bankers; due regard must be paid to the nature and complexity of our present-day finance. If we remember to what a fine art the financing of commercial operations has been reduced, the extent to which our joint stock system has grown, and the conditions under which the modern bank manager in Great Britain works, we shall better understand the need for an individual with specialized skill in the particular branch of finance with which we are dealing. Not the least important of the operations with which the banker is concerned is the acceptance, collection and discounting of bills of exchange, and although the banker exercises a careful control over the main part of the business, yet his multitudinous duties neither allow time for personal visits to the dealers in bills, nor for his attendance on the open market; therefore, the major portion of the discount business has found its way into the hands of the bill specialists.

The bills with which the bill-broker has to deal emanate from various sources; chiefly they are those which enter Great Britain from other countries. At every foreign centre there are always merchants ready to export their wares, and it naturally follows that the funds the bankers receive abroad by the encashment of the drafts sent from London will be utilized for purchasing bills offered by exporters at the foreign cities. The exporters obtain payment for their produce by drawing on London in the 
same way as the shippers here draw on foreign countries, and the net result of the two operations is the influx of bills into England for ultimate circulation on the London discount market.

Documentary bills are not the only ones received from abroad. In any financial centre there will always be a certain number of people desiring to draw bills for services rendered or debts due, and others equally desirous of settling indebtedness to England; consequently many clean bills will also be drawn and sent to London for collection.

To the total of the documentary and other foreign bills seen on our markets has to be added a large number of bills accepted by the finance houses and the London branches of foreign and colonial banks under London accepting credits, and then we have the principal paper with which the bill-broker is concerned in his efforts to meet the investment demand, always in evidence, for this form of bank security. For discount purposes bills may be divided into two great classes-bank paper and trade paper. Bank paper comprises all those bills drawn on and accepted by the great London banks and finance houses. Trade or "white" paper, includes all bills drawn on ordinary merchants and traders, accompanied by documents to be delivered on payment or acceptance. Clean bills are also included in this category, the general criterion being, that the bills should bear on their face a statement that they are drawn against specific shipments. Bills without any such statement, are not undiscountable, but the market exercises a wide discretion, will only take them on certain well-known names, and tends to regard the bills as finance paper of the pig on pork variety.

Bank bills are always discountable at the best rates, but the rate for trade paper is, generally speaking, about $\frac{1}{2}$ per cent. higher than that charged for bank bills of similar usance. If bank paper is discountable at 3 per cent. for a three months' bill, the merchant selling trade 
bills would be charged $3 \frac{1}{2}$ per cent. ; consequently, if the bill were for $£ 100$, the banker would pay $£ 100$ less $3 \frac{1}{2}$ per cent. per annum for three months. However, at the time of writing, owing to the many adverse circumstances there is a difference of about 1 per cent. between the rates charged for discounting bank paper and those exacted for fine trade bills. There is no definite ratio for longer dated paper ; with four and six months' bills, the question of credit enters into the calculation, and the rates paid will depend largely on the probable trend of the market and the standing of the persons whose names appear on the bills.

To return to the bill-broker. In order to be in a position to make or invite definite offers for any of these bills, it is necessary for him to visit daily the offices of those dealing in such paper. At the London offices of the foreign branch banks, for instance, he walks in about eleven o'clock, reports on the likely trend of the discount market, and if there is any business doing, he will procure lists from the foreign bank which give the class, amount and maturities of the bills, and with these in his hands the bill-broker proceeds to the offices of his other clients, the London joint stock banks, finance houses, and Continental bankers, and endeavours to negotiate business. Every discounter, of course, stipulates for an assortment of acceptances, that is to say, a proportion maturing at three, four and six months' date, as it may be necessary to purchase bills which fall due at precisely the time the buyer requires to replenish his treasury in readiness for cash demands. All London bankers have come to know by experience the dates at which calls will be made on their cash balances, and unless anything untoward happens, they can so arrange that payments are made in accordance with their requirements : they simply let their portfolios automatically run out, and then when there is a surplus of cash again, further investments in bills may be made.

Theoretically, a bill-broker is supposed to take all good 
bills offered to him, or, what amounts to the same thing, find purchasers for them, and in practice he rarely declines to do business for his clients.

Just at this point we can see more clearly another reason for the banker's preferring to work through the intermediary of the bill-broker. Owing to his intimate knowledge of the parties to a bill, the broker is able to guarantee the genuineness of all acceptances discounted, and although his own name does not appear on the bills, yet it is his business to see that all acceptances passing through his hands bear the endorsement of the bankers disposing of them, and that they are otherwise in order. A discounter will seldom take these bills without a bank endorsement, and it is the practice of the Bank of England to stipulate for the names of two British firms, one of which must be the acceptor's, on all paper it discounts. When dealing through the bill-broker, too, it is easy for the banks to refuse bills bearing the names of firms which they do not like, or of whose bills they consider they have a sufficient amount in portfolio.

When a purchase has been satisfactorily arranged, the holder of the acceptance simply transfers his title by endorsement, and hands the bills over to the bill-broker against payment of the agreed price. These bills bearing the banker's endorsement are discounted at moderate rates, as the buyer has recourse on the banker in the event of non-payment at maturity.

The major portion of the bills discounted on the London market are, as we have seen, those which have been drawn by foreign exporters on and accepted by British importers, or by the banks who have arranged to accept for them in London, and so it is comparatively easy to get at the respective parties to the bills if anything is wrong, such as refusal to pay at maturity, or anything of that sort. However, the trouble is that among each lot of bills received in London from abroad, there are a number of what are called "foreign domiciles." A foreign domicile bill arises

$14 \mathrm{~A}-(1525)$ 
in the following manner. Out abroad there will perhaps be a French or Italian shipper who draws for his produce under arrangement with the bank that the bills shall be made payable in London. On arrival in London the bills will be sent for acceptance, say, to Paris; they will be accepted in that city, but made payable in London, and will be sent here to the agency of the bank which negotiated them abroad. These bills, being the acceptances of Continental firms and others, are not liked on the London market, and neither the joint stock banks nor the finance houses care to carry them in their portfolios in ordinary times. In recent months foreign domiciles have become undiscountable on the London market, so the foreign and Colonial banks who have received them, are practically obliged to retain them until maturity, which naturally means a bad lock up of funds. Prior to the war a certain proportion was taken in parcels of bills discounted by some of the finance houses; the rest the brokers and discount firms used to take, and in all cases the person disposing of them had to pay a higher rate to those discounters who were agreeable to have them. The Bank of England has consistently refused to receive such paper, and never would discount foreign domiciles in any shape or form, not even when the bills were endorsed by first-class Continental banks.

The determination of the banks to discourage the circulation of foreign domiciles on the London market, led dealers to extend the ban to bills which are termed "Foreign Agencies." Under this heading fall all bills accepted by the London branches and agencies of Continental or other firms established in London, but having the greater part of their assets in foreign centres. The assets, presumably, cannot be considered available in the event of bills being dishonoured; consequently, there is a marked tendency to discriminate against the paper. These foreign agency bills are discountable to a limited extent only, and those selling the paper are penalized in the 
rates charged, which are usually $\frac{1}{16}$ per cent. to $\frac{1}{8}$ per cent. higher than those for which first-class English domicile bills can be sold.

Before we leave this subject of discounting there is one question to which special reference ought to be made. When discussing documentary bills, we saw that two kinds were drawn-the one is called a "D/A " bill, the other a " $\mathrm{D} / \mathrm{P}$ " bill-and in either case, whether the bills are drawn from London on a foreign port, or from the foreign centre on London, the D/A bill, bearing the clause " documents on acceptance," is much more useful to the banker ; in each discount market the buyers of bills under discount know that the parties to the instrument must be of fair financial standing, and consequently, the banker has no difficulty in getting the bill discounted through the broker at a good rate. The $\mathrm{D} / \mathrm{P}$ bill, which either contains the clause "documents on payment," or has a slip attached bearing those words, is obviously not good for discount purposes, and the banker is generally compelled to hold it until maturity, or until the acceptor retires it under rebate. It is not exactly a matter of caprice whether the drawee pays the draft one day after acceptance, or whether he lets the bill run its full term; it all depends on whether he can sell the relative goods promptly. If a quick sale is made, the acceptor will be only too glad to take up the bill under the usual rebate. There are times, however, when these $\mathrm{D} / \mathrm{P}$ bills can be sold under discount, and in such cases they are discounted as clean bills, and the bank selling the paper transfers the bills to the buyers and retains the documents. But it not infrequently happens when a bank has parted with the $\mathrm{D} / \mathrm{P}$ bills in this way, that the acceptor comes along and wishes to exercise his right to take up his bill before maturity. What can the banker then do? He might as well hunt for the proverbial needle in a haystack as to try to trace the bill on the market, so to get out of the difficulty he receives the amount of the draft, less rebate for the unexpired time, from the 
acceptor, hands him the documents of title to the goods, and at the same time gives him a guarantee that the bank will produce the discharged bill to him at maturity. In a word, the banker receives the cash and undertakes to pay the bill himself at due date.

In all this bill business the services of the broker are in constant request, and the fact that he is at the beck and call of nearly every bank in the kingdom is perhaps responsible for his being dubbed the Jackal attendant upon the King of Beasts, the King of Beasts, according to the broker, being the banker. We have also seen the billbroker described as the dog which ate of the crumbs, while in other quarters he is styled the aristocrat of the money market. When we find all these epithets levelled at the head of the inoffensive broker, we might expect him to be exacting a large tribute for his services; but that is not the case. For his extensive knowledge and responsible work the bill-broker receives but a trifling commission; why, then, is he prepared to act as an intermediary in this business, and is it worth his while? The answer is a simple one. The smallness of the broker's commission is no criterion of his profit: rapidity of turnover is one prominent factor; the total amount of each parcel of bills is another. A $\frac{1}{32}$ per cent. or even $\frac{1}{16}$ per cent. added by the broker to the rate charged for discounting a single bill is infinitesimal, but when reckoned on a large number of acceptances the commission is not inconsiderable.

Then as to his capital. It has been cynically remarked that all the bill-broker's capital consists of, is a pair of boots and a bill case. He does not need a large initial capital, it is true, but his position is not quite so bad as that. There is no doubt, however, that every bill-broker is indebted to the bankers for a large proportion of the capital used in his business, and as such funds are loaned out to him by the bankers very cheaply, we see how it is he is able to work at very low rates. The money is lent to the bill-broker at " call "-sometimes merely over-night, 
and it is his practice to find out each morning which banks are lenders and which are likely to call in funds; he is then in a position to base his operations on the amount of money available in the market. Where the broker is able to borrow easily, he offers a low rate of interest, but if the banks are not well-supplied with cash he has to pay more for the accommodation, and in case of need he may be forced to resort to the Bank of England, who will supply funds by discounting the cream of the bills for him.

As security for "call" loans the bill-broker deposits with the banks bearer stocks of the "floater" or " terminal" type, such as consols, exchequer bonds, Treasury bills, and the better class Indian Railway stocks; or he may, in some cases, deposit batches of first-class acceptances.

In view of the fact that the bill-broker is a constant user of surplus funds held by the banks, it is safe to assume that he contributes largely to the profits made by the bankers, and, for the rest, those who are inclined to gird against the profits the bill-broker in his turn makes on discount transactions, have but to make a cursory examination of his operations on the London money market to be convinced that the intricacies of the business are ample justification for his presence in their midst.

At the present day centralization of interests is no less apparent in bill-broking than in banking. There is an increasing tendency to divert business from the billbroker, who works solely on commission, to the dealer who buys bills outright and sells them on his own account: it is the latter class, in fact, that is mainly responsible for borrowing "call" money from the banks. To carry the competition still further, companies have been formed to deal exclusively with this discount business, and, to judge by the dividends paid, they have found a profitable field for their operations. Unlike the ordinary brokers, however, the discount companies are not wholly reliant on funds borrowed from the banks; they receive money on 
deposit from outside sources, and as, by offering higher rates of interest, they sometimes obtain cash which, but for their existence, would have gone into the banks' coffers, it is they rather than the " running " broker, who must be looked upon as active competitors in the banking world.

\section{Treasury Bills.}

In conclusion, we may refer briefly to the Government measures for financing the Great War by means of Treasury bills. Formerly Treasury bills were issued by tender. A certain specified amount was announced as being for sale, and the bills were allotted to those charging the lowest rate of discount. This was the practice in vogue until the 14th April, 1915, when the British Government suddenly announced in the London Gazette its intention to issue three, six and nine months' Treasury bills until further notice at fixed rates of discount. In the first instance, the rates published by the Treasury were: for three months' bills, $2 \frac{3}{4}$ per cent.; six months' bills, $3 \frac{5}{8}$ per cent., and nine months' bills, $3 \frac{3}{4}$ per cent. Subsequently, twelve months' bills were announced to be available at the same rate as for nine months' paper. The Government, however, reserved to itself the right to vary these rates whenever considered advisable so to do, without previous notice to the market.

The presence of these Treasury bills on the market must necessarily affect the price of all other bills sold under discount; the purchase of the Treasury paper tends to absorb the excess supply of floating money on the short loan fund of the London money market, and consequently helps to keep up the bankers' rates for money at call and short notice, which in turn affect the discount rates for both trade and bank bills. The reader has only to refer to the various illustrations we have given throughout this book to see how the various influences react the one on the other.

Finally, the market finds itself committed to rates for 
bank paper from which it is practically impossible to depart as long as the Treasury bills are on offer at fixed prices; by force of the Government competition it is bound to work at practically the same rates of discount for three, four and six months' bank bills as those charged by the Treasury for its paper, as obviously no buyer is likely to pay a higher price for a bank acceptance than that at which he can get a Treasury bill issued on Government security. At the time of writing, the market is thus, to all intents and purposes, under the direct control of the Government, and as long as the sales of Treasury bills are continued, the free play of the usual factors is restrained.

It scems a curious termination to this book to have to admit this fact in face of the theories we have expounded, but there it is, and all we can do is to recommend the reader to continue to examine for himself the varying effects of the British Treasury's experiment with the London discount market: the study should prove an interesting one. 


\section{INDEX}

Acceptance Credits, see Bank Rate, 63, 85

"Credits"

Acceptances, see "Bills"

Advances, Bankers' on bills, 196 up-country, 196

America, United States of, Bills on, 187-8

- - Exchange Rates, 46

during Great War, 110

- - Gold Points, 28, 111

- - , Gold policy, 36

cost of, 111

Gold shipments,

- - Mint Par, 21, 22

- - Monetary position on outbreak of War, 99

$-\ldots$, Trade balance, 113

Arbitrage operations, 75-9

Argentine Republic, Bills on, 188,189

118

Gold, premium on, Note issues, 119

Australia, Bills on, 17, 182

- Exchange between and

England, 14, 182

- Grain exports, 17

Mint Par, 15, 22

17

, Telegraphic Transfers on,

Trade Balance, 15, 16

Wool exports, 17

Austria, Mint Par, 22

Standard " see "Gold Exchange

Austro-Hungarian Bank, investment of its assets, 82 , cover for notes, 124

BANk Charter Act, Suspension of avoided, 99

Bank paper, 25, 53, 76

of Egypt, 195

of England, Gold Reserve, 87,90

- Its position during

Great War, 97-9 exchanges, 88-90

ket, 86-8, effect on mar-

- - and Market Rate of

discount, their inter-connexion 87, 88

banker, Connecting link letween exchange dealers, 10

- his stock of international currency, 10

Bankers' Commissions, Influence on the exchanges, 70

— Credits, see "Credits"

- Investments in Bills, 80

Barter, 4

Belgium, Mint Par, 22

Berlin, Its money market on outbreak of Great War, 96

Bill, Discounting a, 6, 198

Bill-broker, The, 201

—, his capital, 86, 208

- Position on Discount Market, 201

208 , on Money Market,

Bill of Exchange, what it includes, 11

Bill of Lading, Attached to Bill of Exchange, 162

served, 162

—- marked "freight paid," '162

- - , property in, 162-3

—_ “ " to order," 162

- under Customs (War

Powers) Act, 1915, 162

Bills, Acceptance by banks, 153, 165,170

-C, Accommodation, 195

- as a means of attracting gold, 81,88

", Bank, 25. , See also "Finance Bills" 136

$86,91,97-8$

Rate, increases in

of France, Rate, 91

- 80 , Bankers' investments in,

- Clean, 160, 203 
Bills, Continental investments in, 81,88

- , cost of, accepted by bankers compared with exporters' drawings, 172

- . country drawing setties rates, 139

- - crop requirement drawings, 196-7

- , currency, 167

—_, demand, 190

__, difference in rates, how calculated, 62

- Documentary, bankers' security, 161

- - demand, 190

cribed, 162 the documents des-

- Documents on acceptance, 161,207

- 162 , 176,207

-, Exchange dealers' profit on, 30,31

- , Finance, Influence on Exchanges, 73

- - price, 194

—_ $\ldots$ renewal of, 74,193

—_ - varieties of, 193 et

seq.

- for collection, 175

—, Foreign Agencies, 206

- - domiciles, 205

- - - investment in, 81-8

- - , proceeds of, how remitted home, $170,173,176$, 183

- Forms of, drawn under credits, 158 et seq.

—, Gold basis, 68

—., House paper, 196

- Interest, 171

—-

- $v$. bankers' accep-

tances, 172

- Kite-flyers, 195

—. Margin on, 174

— of Exchange Act, 44

- on Argentina, 189

- on Australia, 17, 182

- on Denmark, 190

- on Denmark, return remittances, 190

- on Egypt, 184

- on London, 67
Bills on Scandinavian countries, 190

— on South Africa, 184 - American States, 188

- on The Far East, 171

- on United States of

America, 187

— paid under rebate, 180 , Partial deliveries of goods

against, 180

- , Pig on pork drawings, 196

-, Price of, 27

_., Standing and responsibil-

ity of parties to, see

"Opinion Lists"

-, Trade, 53, 203

_ under London Acceptance credits, 165

Bolivia, Bills on, 189

Brazil, Bills on, 189

—., Paper currency, 119

CALL Loans, 209

Chain Rule, 19

Cheque Rate, see "Exchange, short"

Chile, Bills on, 189

—., Paper currency, 119

China, Currency of, 131

- Exports to, how affected by price of silver, 133

- Investors in affected by

fall in price of silver, 134

Clean Credit, see "Credits"

Columbia, Bills on, 189

Commercial Paper, 54

Confirmed credits, see "Credits"

Consular certificates, 164

Council Bills, India, 128

,$---\longrightarrow$ Reverse, 127

Telegraphic Transfers, 128

Bills and Telegraphic

Transfer, method of issue, 128

Counter remittances, 166

Coupons, a means of remittance, 11

Course of Exchange, quotations, $49,50,51$

Credit Lists, see " Opinion List "

Credits, Bills drawn under, 158 et seq., 165

- Cancellation of, 147, 148

- Clean, 151

—, Confirmed Banker's, 148 
Credits, Documentary, 152

- - - and Confirmed, dif-

ference between, 153

- Irrevocable, 151

- London acceptance, 154

- Revocation of, 147-s

- Revolving, $15 \overline{3}$

- Travelling Letters of, 145

- Unconfirmed banker's,

148

- - , cancellation of, 150

Without Recourse, 150

Customs, War Powers Act, 162,

DeBts, between two countries, how collected, $6,7,8$

- , purchase and sale of foreign, 4, 5, 6

Denmark, Bills on, 190

- Mint Par, 22

Discount market, The, 85 et seq.

_- rate, raising of, see "Bank of England "

Discounting a bill, 6, 198

class of bills, 19: et seq.

-..., Private bankers and, 201

Documentary Bills, see "Bills"

- Credit, see "Credits"

Documents on acceptance, see "Bills"

_ on payment, see "Bills "

__ on payment bills, how discounted, 207

Dollars, chopped, 132

Dutch Exchange, see " Holland '

EASTERn countries, Bills on, 135, I36, I38

- Exchanges, The, 121

\section{5}

Economist's rates, 32,37

Egypt, Bills on, 184

Exchange, Arbitrage operations, their effect on, 74

— as per endorsement, 141

their effect on, 71

- Banking influences, 74

_- Course of, see " Course of Exchange "

-, Favourable, 62

- Finance Bills, influence on, 73

- - Forward contracts, 142
Exchange Fluctuations, Causes and effects, 61 et seq.

-.- Fluctuations, 65

$-\longrightarrow$, Limits of, 66

- Influence of Trade conditions on, 66,67

- - Long, 47, 48, 55

Q Quotations, see "Foreign

Exchange"

__ - Rates of, see "Rates"

Remittances from Foreign

Residents, 69

- Risks, elimination of, 142

- -, Short, 47, 48

- Stock Exchange influences, 71

- Unfavourable, $62,63,114$

- - encouragement to

exporters, discouragement to importers, 65

- When at a discount, 62

- - premium, 62

Exchanges, Effect of War on, 100

- Silver, see " Eastern Exchanges "

- Tables of rates during

War, 100, $10 \mathrm{I}$

Exports, 9

$\longrightarrow$, Invisible, 9, 69

Exporters, how they obtain payment for their produce, I68

Friance Bills, Effect on exchanges, see "Bills"

"Bills", Varieties of, see

Floaters, 210

Foreign Agency Bills, see "Bills"

__ Domicile Bills, see "Bills" Foreign Exchange, Definition of, 3

- - Nature of the commodities bought and sold in, 4,6

100 Quotations, 39, 40, 100 - See also "Exchange"

- Study of, what it enables the student to do, 2 Foreign Exchanges, Meaning of, 3

Securities, British investments in, 71-2

- — Income from, 72 
Foreign Trade, see "Trade" France, Foreign Exchanges during Great War, 103

-_, Gold Policy, 36

$\longrightarrow$ Mint Par, 19, 20, 22

Freight, 162

Germany, Foreign exchanges during Great War, 103

-, Gold Policy, 37

- Mint Par, 20, 22

Go-down, 178

Gold, American shipments, cost, 28,111

France, 112

- - Deposits in Ottawa account Great Britain, 112

- , French shipments, cost, 33

___ from Germany during War, 104

- - German shipments, cost, 33

- movements, effect on exchanges, 94

— Points, 23, 28, 29, 33, 34

33

Reserves, 32-S, 90

- Exchange Standard, explained, 123 et seq.

$124,-12$ in Austria,
$-126,-125-$ in India, 122,

Great Britain, Free Gold Market, 35

Holland, Exchange, 105

- Mint Par, 22

Hong-Kiong, Currency of, 132

House-paper, 196

Hypothecation, Letter of, 164

Hypothetical Par, 13

IDEAL or Hypothetical Par, 13

Imports, 9

—. Invisible, 9, 69

India, Currency position, 123 122

- , Trade of, 125

Indian Exchange during Great War, 127
Indian Exchange, How maintained by Government, 126 change Standard"

Insurance, Certificates of, 163

Policies, 163

Interest Bills, see "Bills"

International Currency, 10, I 1

— Indebtedness, basis of, 8, 9

Irrevocable Credits, see

"Credits"

Italian Exchange, 106, 118

Italy's Note issues, 118

KITE-FLYING, 195

linibbs, G. H., 15

LETTER of Hypothecation, see "Hypothecation"

Letters of Credit, influence on Exchanges, 74

Loans, their effect on the Exchanges, 72, 73

Long Exchange, see "Exchange"

London Acceptance credits, see "Credits"

- Money market on outbreak of War, 96

-,$\frac{}{87} \longrightarrow$ manipulation Stock Exchange closed, 97

MACLEOD, H. D., 5

Marginal Deposit Receipts, 174

Market Rate, 86

Markets, Produce, War's effect on, 101

Mercantile Theory, 63

Mexico, Bills on, 188

Mexican Dollars, 131

Mint Par of Exchange, 13, 15, $19,20,21,22,23$

Money Article, The, 39

- Markets, War's effect on, 92

- Price of compared with wheat, 5

New York, Berlin, Par of exchange, 103

- , Exchange quotations, 45, 46,47

Norway, Mint Par, 22

"On-Change" Table, see "Course of Exchange"

Opinion Lists, 16s 
Outward shipments, Financing, 170

PAPER Money, Effect on exchanges, 116 et seq.

- — Inventor of, 116

- - Issue of, drives gold out of circulation, 116

120

Issues during Great War,

- — - effect on trade, 117

Par, see "Ideal Par"

-, see "Mint Par"

- relative, 137

Paris, Its money market on outbreak of Great War, 93, 94,95

Partial deliveries, 176, 180

Peru, bills on, 189

Philippines, see "Gold Exchange Standard "'

RATES of Exchange, for and against London, 41, 113

—_ High, 41

42,46

in foreign units, 41,

- in pence, 55,64

$\ldots$ in Silver Standard countries, 135

- - Low, 41.

See also "Exchange"

- - "Tel Quel," 57

Re-discounting, 200

Reichsbank Rate, 91

—_, Gold Policy, 37, 38

Remittance, forms of, 11

Revolving Credits, see " Credits"

Rouble, Depreciation in value, reasons for, 106

Royal Exchange, 49

Rupee, How its parity is maintained, 126

Rupees, How procured in India, 128

Russian Exchange, British Government's action, 108, 109

Russia's Exchanges during Great War, 106

Russia, Imperial Bank of, its Gold Reserve, 110

SALE of Goods Act, 163

Scandinavian Union, 190

Shanghai, exchange quotations, 135

—
Short Exchange, see "Exchange" Rate, see "Exchange

Sight Rate, see "Exchange, short"

Silver, Depreciation in price of, 121

- $-\longrightarrow$, its effect on

trade, 134

—_ Exchanges, see "Eastern Exchanges " "China"

- Fluctuations in price of, 122,133

- Problem, India and, 122

Standard Countries, Specie Points, 138

Specie Trade of, 134

Points, see "Gold Points"

- - see "Silver Stan-

dard countries"

South Africa, bills on, 184

- America, bills on, 188

—_ - - Paper issues, 118

Sovereigns, Shield, 104

- - , shipments to India, 128

Spectator, The, 109

Stock Exchanges, Closing of, 97

Sweden, Mint Par, 22

Sycee, 132

TAEL, A standard of weight, 131

- Unit of currency, 131

Tale Quale, see " Tel Quel "

Tel Quel Rates, 57

Telegraphic Transfers, 46

Terminals, 209

Times, The, 39, 50, 58

Trade, Foreign, 8, 9

Travelling Letters of Credit, see "Credits"

Treasury Bills, Russian issue in London, 108

- — - War financed by, 108,210

Trust Receipts, 177

\section{8}

WAR, Its effect on World's Foreign Exchanges, 96, 100, et seq.

_- London Banks' action at commencement of, 98

—_ Powers Act, see "Customs"

Printed by Sir Isaac Pitman \& Sans, Ltd., Bath, England 


\section{Pitman's}

\section{Business Handbooks}

\section{A Selected List of Practical Guides for Business Men and Advanced Students}

\section{CONTENTS}

PAGE

ADVERTISING AS A BUSINESS FORCE 15

ADS AND SALES.

INCOME TAX LAW

PAGE

. .12

ADVANCED ACCOUNTS 9

ACCOUNTS OF EXECUTORS . . 10

ACCOUNTANCY • . . 9

AUDITING, ACCOUNTING, AND BANKING 9

AUDITING, THE PRINCIPLES OF • 9

BALANCE SHEETS

BANK ORGANISATION, MANAGEMENT

AND ACCOUNTS

INDUSTRIAL TRAFFIC MANAGEMENT 16

INSURANCE

INSURANCE OFFICE ORGANISATION, ETC.

LAW RELATING TO THE CHILD 11

LAW RELATING TO SECRET COM-

MISSIONS, ETC. . . . 12

LAW OF EVIDENCE . . . 13

5 LAW OF PROCEDURE . . . 13

LAW OF REPAIRS . . . . 13

BANKRUPTCY, DEEDS OF ARRANGE-

MENT, AND BILLS OF SALE $\quad 10$

BILLS, CHEQUES, AND NOTES 7

BUSINESS MIAN'S GUIDE • . 2

CARRIAGE, LAW OF $\quad . \quad$. 12

CHAIRMAN'S MANUAL . . . 3

CLUBS AND THEIR MANAGEMENT : 3

" COLE" CODE DICTIONARY . . 16

COLLIERY OFFICE ORGANISATION • 6

COMPANY ACCOUNTS • • . 9

COMMERCIAL ENCYCLOPEDIA . 2

COMPANIES AND COMPANY LAW .12

COMPANY CASE LAW . . . 12

CONSULAR REQUIREMENTS : . 14

COST ACCOUNTS . . . 9

COUNTING HOUSE AND FACTORY

ORGANISATION . . . . 4

DICTIONARY OF BANKING • • 6

DICTIONARY OF COMMERCIAL CORRESPONDENCE

LICENSING, GUIDE TO THE LAW OF 11

LECTURES ON BRITISH COMMERCE 3

MANUFACTURING BOOK-KEEPING

AND COSTS. . . 10

MARINE LAW . . . . . 11

MERCANTILE LAW . . . 11

MONEY, EXCHANGE, AND BANKING 6 MUNICIPAL OFFICE ORGANISATION , 4

OFFICE ORGANISATION . . 4

OUTLINES OF THE ECONOMIC HISTORY

OF ENGLAND. . . . 16

PRINCIPLES OF PRACTICAL PUBLICITY 14

PRACTICAL BANKING • • • 6

PRACTICAL SALESMANSHIP • 15

PROSPECTUSES ..$\quad \cdot \quad \cdot 7$

PUBLIC MAN'S GUIDE . . . 2

PSYCHOLOGY OF ADVERTISING . 14

RAILWAY ACCOUNTS . . . 10

RAILWAY REBATES CASE LAW - 11

SECRETARY'S HANDBOOK . . 7

DICTIONARY, PORTUGUESE AND ENGLISH $\quad . \quad$. $\quad .13$

DICTIONARY (ABRIDGED), PORTUGUESE AND ENGLISH . . 14

DICTIONARY OF SECRETARIAL LAW 8 DICTIONARY OF THE WORLD'S COMMERCIAL PRODUCTS.

DRAPERY BUSINESS ORGANISATION 5 ECONOMIC GEOGRAPHY . . 16 GROCERY BUSINESS ORGANISATION 5 GOLD MINE ACCOUNTS . . . 10 GUIDE FOR THE COMPANY SECRETARY 7 HANDBOOK OF LOCAL GOVERNMENT LAW SHIPPING OFFICE ORGANISATION, ETC. 5 SOLICITOR'S OFFICE ORGANISATION, ETC. SPANISH CONIMERCIAL DICTIONARY 11 STOCK EXCHANGE . . . 10 STOCK-BROKER'S OFFICE ORGANISATION. . . SYSTEMATIC INDEXING $\quad \cdot \quad \cdot 15$ TELEGRAPH CIPHERS . . . 15 TRAFFIC IANAGEMENT, INDUSTRIAL 16 TRANSFER OF STOCKS AND SHARES 7 TRANSPORT, THE IISTORY AND ECOMICS OF.

THEORY AND PRACTICE OF ADVERTISING

PORT, THE • . . . 16 HOUSEHOLD LAW $\quad \cdot \quad \cdot \quad 11$ INCOME TAX PRACTICE . . $\$$

SIR ISAAC PITMAN \& SONS, LTD., I AMEN CORNER, E.C. BATH, NEW YORK AND MELBOURNE 


\section{COMMERCIAL ENCYCLOPAEDIA AND DICTIONARY OF}

BUSINESS. A reliable and comprehensive work of reference on all commercial subjects, specially designed and written for the busy merchant, the commercial student, and the modern man of affairs. Edited by J. A. Slater, B.A., LL.B. (Lond.). Of the Middle Temble and North-Eastcrn Circuit, Barrister-atLaw. Author of "Mercantile Law," "Commercial Law," etc., etc. Assisted by upwards of 50 specialists as contributors. With numerous maps, illustrations, facsimile business forms and legal documents, diagrams, etc. In 4 vols., large crown 4 to (each 450 pp.), cloth gilt, $£ 1$ 10s. net. Half-leather gilt, $£ 2$ 2s. net.

. We bave found it of an extremely interesting nature, and can strongly recommend it to all wishing to keep thoroughly up to date in commercial and business life. The high standard which Messrs. Pitman have attained in previous volumes published by them is fully sustained in the Commercial Encyclopacdia, a strong feature of which is the extremely low price fixed for what may be regarded as a very important work of reference."-The Statist.

"Providing, within adequate limits, full and accurate information upon every subject which can be legitimately claimed to fall within the scope of business life, this new work must appeal with peculiar force to all classes of the commercial community ... should prove a more valuable possession to the business man than half-a-dozen dead languages and all the book-lore of 3,000 years."-The Standard.

BUSINESS MAN'S GUIDE. Sixth Rerised Edition. With French, German, and Spanish equivalents for the Commercial Words and Terms. Edited by J. A. Slater, B.A., LL.B. (Lond.). This is a volume of handy size, designed to be of permanent usefulness in the office of the merchant, the banker, the broker, and the trader, and to all members of the staff. The work includes over 2,000 articles. In crown $8 \mathrm{vo}$, cloth gilt, $520 \mathrm{pp}$., 3s. 6 d. net.

"An admirable specimen of the new type of business instruction book. In 500 closely printed pages, with subjects arranged alphabetically, it packs away a great amount of information of the kind frequently required and not easily obtained by business men of many kinds. The fulness of the technical phraseology, with foreign equivalents, is one of the best features of the book. One may search any ordinary dictionary in vain for explanations of such phrases as 'bottomry bond,' 'hypothec,' 'quintal,' or 'fittage.' The summarised information of trade customs, of foreign practice, and of commercial law, is given with great lucidity. Altogether it is a book that can be heartily recommended."-Daily Mail.

PUBLIC MAN'S GUIDE. A Handbook for all who take an interest in questions of the day. Edited by J. A. Slater, B.A., LL.B. (Lond.). The object of this book is to enable its readers to find within a comparatively compact compass information on any subject which can possibly bear upon matters political, diplomatic, municipal, or imperial. In crown 8vo, 444 pp., cloth gilt, 3s. 6d. net.

"Comprehensive and concise are the two adjectives which best describe the "Public Man's Guide,' to which might be added indispensable."-Westminster Gazette. 
LECTURES ON BRITISH COMMERCE, including Finance, Insurance, Business and Industry. By the RT. HON. FREDERICK Huth Jackson, G. Armitage-Smith, M.A., D.Litt., Robert Bruce, C.B., Sir Douglas Owen, W. E. Barling, J. J. Bisgood, B.A., Allax Greeninell, F.G.S., Janes Graham. With a Preface by the Hox. IV. Pexiber Reeves. In demy 8 ro, cloth gilt, 295 pp., 7s. 6d. net.

Contents.-The Bank of England-The British System of Taxation-The London Postal Service-London as a Port-The Machinery of Marine Insurance-British Shipping-Fire Assurance, Life Assurance-Industrial Life Assurance, Personal Accident and Sickness Insurance, Workmen's Compensation Assurance, Motor-Car Insurance, Burglary Assurance, etc.-The Economic Position of the Coal lndustry of the United Kingdom-The Woollen Industry.

CLUBS AND THEIR MANAGEMENT. By Francis W. Pixley, F.C.A., of the Middle Temple, Barrister-at-Law. In demy 8vo, cloth gilt, 240 pp., 7s. 6d. net.

The author of this book, who for some twelve years was on the committee of one of the leading London Clubs, is a past President of the Institute of Chartered Accountants, and Auditor of a number of Club and Hotel Accounts. It is believed that the work will appeal not only to members of Club Committees and Secretaries, but to Members of Clubs in England, in our oversea Dominions, and in America. It has nothing to do with the history of Clubs but with their practical management, and contains in detail the duties of every official of a Club from the Members of the Committee to the Hall Porter. Forms of accounts, specimen rules and by-laws, and a vast amount of general information help to complete the volume.

THE CHAIRMAN'S MANUAL. Being a guide to the management of meetings in general, and of meetings of local authorities, with separate and complete treatment of the meetings of public companies. By Gurdon Palin, of Gray's Inn, Barrister-atLaw, and ERNest Martin, F.C.I.S. In crown 8vo, cloth gilt, 192 pp., 2s. 6d. net.

"We only wish that it were a sine qua non that no chairman should be allowed to occupy that position unless he could show that he had carefully perused this little book. We strongly urge all our readers to obtain a copy."-Accountant's Journal.

INSURANCE. A Practical Exposition for the Student and Business Man. By T. E. Yourg, B.A., F.R.A.S., ex-President of the Institute of Actuaries. With a Practical Section on Workmen's Compensation Insurance, by W. R. Strorg, F.I.A.; and the National Insurance Scheme, by Vyvyax Marr, F.F.A., F.I.A. Third Edition, Revised and Enlarged. In demy 8ro, cloth gilt, 423 pp. 7s. 6d. net.

" Not only the principles and methods of the ordinary office work in its various departments is explained, but practical questions which arise in the conduct of the business are elucidated. But though the work was prepared with a special view to the classes named, there are few professional insurance men who would not find it a valuable work of reference."-Insurance Monitor. 
INSURANCE OFFICE ORGANISATION, MANAGEMENT, AND ACCOUNTS. By T. E. Young, B.A., F.R.A.S., and RICHARD Masters, A.C.A. Second Edition, Revised. In demy 8vo, cloth gilt, 150 pp., 3s. 6 d. net.

"Here we have a work that does thoroughly fulfil its purpose as a guide to organisation, management, and method of account-keeping in commercial undertakings. ... We have no hesitation in saying that the GuIDE provided by Mr. Young and Mr. Masters is not only thoroughly practical, but is a storehouse of wise counsel, whose value to the business man generally, no less than to the insurance specialist, cannot easily be exaggerated."-Insurance Journal.

\section{OFFICE ORGANISATION AND MANAGEMENT. Including}

Secretarial Work. By LAwrence R. Dicksee, M.Com., F.C.A., and H. E. Blais, Late Tramways Manager, County Borough of West Ham. In demy 8ro, cloth gilt, 306 pp., 5s. net.

" We have scarcelv ever seen an office manual so complete and reliable as this one. The chapters on office management are compact with useful information, the ripe fruit of experience."-Manchester City News.

"An enormous amount of useful information is comprised in the 300 pages of which the work consists."-Accountant.

COUNTING HOUSE AND FACTORY ORGANISATION. A Practical Manual of Modern Methods applied to the Counting House and Factory. By J. Gilmour Williamson, Holder of Business Diploma of the Heriot-Watt College, Edinburgh, etc. In demy 8vo, cloth gilt, 182 pp., 5s. net.

"The volume deals exhaustively with the subject from all aspects, in some seventeen chapters, and discusses the work of the various departments of a business house from a practical standpoint. Theories are rightly eschewed. The work will undoubt. edly receive a welcome from manufacturers who are aiming at efficiency, and who are anxious to inaugurate system or reorganise on reliable and tried lines, and there are doubtless not a few who are on the look out for a comprehensive volume containitig practical hints."-Hardware Trade Journal.

\section{MUNICIPAL OFFICE ORGANISATION AND MANAGEMENT.}

A Comprehensive Manual of Information and Direction on matters connected with the work of Officials of Municipalities. Edited by William Bateson, A.C.A., F.S.A.A., Borough Treasurer for the County Borough of Blackpool. With contributions by eminent authorities on Municipal Work and Practice. In crown 4to, half-leather gilt, with about 250 diagrams and forms, 503 pages. 25s. net.

"This original publication is certain to receive a deserved welcome from the municjpal world. Here we have the multitudinous operations of municipal work explained in a practical way for practical unen; the law coded in as simple a way as possible, and the manner in which it is carried out illustrated by text, diagrams, and official forms. Naturally, the book teems with new ideas and fresh methods for performing the work of the different departments, and this feature alone will appeal to town clerks, engineers, surveyors, managers and accountants on the look out for points and ideas."-Municipal Journal. 
SHIPPING OFFICE ORGANISATION, MANAGEMENT, AND ACCOUNTS. A comprehensive Guide to the innumerable details connected with the Shipping Trade. By ALFred Calvert. In demy 8vo, cloth gilt, $203 \mathrm{pp}$., with numerous forms, $5 \mathrm{~s}$. net.

"This is the most practical handbook on the subject that we have seen. It is in the presentation line by line, in any part of the book, of the subject-matter treated. that the author shows his complete and intimate knowledge of the practice of the shipping trade. There is nothing dead or too theoretic about Mr. Calvert's book, and his method of explanation is eminently clear and forcible. We can confidently recommend the work. The book fully answers and makes good its title."Manchester Guardian.

SOLICITOR'S OFFICE ORGANISATION, MANAGEMENT, AND ACCOUNTS. By E. A. COPE and H. IV. H. Robins. In demy $8 \mathrm{vo}$, cloth gilt, with numerous forms, 5 s. net.

"The volume is rendered complete by the publication of numerous forms and diagrams, and the authors are to be congratulated on the thoroughness with which they have performed their task. We have no doubt whatever that the book will be extremely useful to the parties for whom it is intended." - Birmingham Chamber of Commerce Journal.

GROCERY BUSINESS ORGANISATION AND MANAGEMENT. By C. L. T. BEEchING, Organising Secretary of the Institute of Certificated Grocers. With Chapters on Buying a Business, Grocers' Office Work and Book-keeping, and a Model set of Grocers' Accounts. By J. Arthur SMart. In demy 8vo, cloth gilt, about $160 \mathrm{pp}$, with illustrations, $5 \mathrm{~s}$. net.

"The authors can speak with authority of the things of which they write, and they give us of their best. The book has twenty chaptcrs, the topics of which extend from 'buving a business' to 'trading results.' Mr. Smart deals fully with the grocer's office work and book-keeping, and gives an admirable set of grocer's accounts . . the work is well done throughout . . . it will be read with profit and pleasure." Grocer.

DRAPERY BUSINESS ORGANISATION AND MANAGEMENT. By J. ERnest Bayley. In demy 8vo, cloth gilt, 300 pp., 5s. net.

"The author has evidently spared no pains to make his work interesting, and in this he has so well succeeded that it can be read with advantage by both beginners and experts in the dry goods trade."-Financial Times.

BANK ORGANISATION, MANAGEMENT, AND ACCOUNTS. By J. F. DAvis, D.Lit.. M.A.. LL.B. (Lond.). Lesturer in Banking and Finance at the City of London College, In demy 8vo, cloth gilt, with forms, $5 \mathrm{~s}$. net.

"It is concisely and clearly written, and the many examples of rulings of books and specimens of vouchers and forms in use form admirable illustrations to the text. The work should fulfil a useful purpose in providing the general survey of banking which has hitherto been lacking."-Financial Times. 
STOCKBROKER'S OFFICE ORGANISATION, MANAGEMENT AND ACCOUNTS. By Julius E. DAY, Manager to an Inside Firm of Stockbrokers on the London Stock Exchange. In demy 8vo, cloth gilt, 243 pp., 7s. 6d. net.

"Without doubt there is a distinct need for this book, for it deals lucidly with many puzzling points of interest to the investor ... The author is to be congratulated upon his achievement in grappling so successfully with a difficult task, for the book will prove an asset of considerable value to the beginner, and a work of undeniable interest to "The man in ThrogmortonStreet." "-Joint Stock Companies' Joumal.

COLLIERY OFFICE ORGANISATION AND ACCOUNTS. By J. W. Innes, F.C.A. (Swithinbank Innes \& Co., Chartered Accountants), and T. Colin Campbell, F.C.I., for many years Managing Clerk to a large Colliery Company, and now a principal Book-keeper at one of the largest Collieries in England. In demy 8vo, cloth gilt. 5s. net.

"This is a very useful book. It provides a manual for officials in a colliery office as well as affording many hints to those engaged as merchants and factors in the merchanting and distribution of coal. The work is certainly one which should find a place on the bookshelves of all those who are engaged in colliery working." - Iron and Coal Trades Review.

MONEY, EXCHANGE, AND BANKING, in their Practical, Theoretical, and Legal Aspects. A complete Manual for Bank Officials, Business Men, and Students of Commerce. By H. T. EAston, of the Union of London and Smith's Bank, Ltd., Associate of the Institute of Bankers. Second Edition, Revised. In demy $8 \mathrm{vo}$, cloth gilt, 312 pp., $5 \mathrm{~s}$. net.

"Mr. Easton's book can be commended to every one desiring guidance and instruction in the mysteries of money and exchange, and the theory and practice of banking."-Truth.

DICTIONARY OF BANKING. A Complete Encyclopaedia of Banking Law and Practice. By W. Thomson, Bank Inspector. With a section on the Irish Land Laws in their relation to Banking, by Lloyd Christian, Secretary to the Institute of Bankers in Ireland. In crown 4to, half-leather gilt, 563 pp., 21s. net.

" Since the publication some years ago of Sir Inglis Palgrave's famous 'Dictionary of 'Political Economy' we have been favoured with no work of reference so useful to bankers as the one which has just beer compiled by Mr. Thomson. Mr. Thomson bas succeeded in his object of compiling a work which shall be of use both to the banking student and to the practical banker who requires information in a hurry."Bankers' Magazine.

PRACTICAL BANKING. Including Currency. A Guide to Modern Banking Practice and the Principles of Currency. By J. F. G. Bagshaw, Associate of the Institute of Bankers, and C. F. HanNaford, Associate of the Institute of Bankers, Examiner in Banking and Currency to the London Chamber of Commerce. In demy 8 vo, cloth gilt, 333 pp., 5s. net.

"This work is intended as a guide to modern banking practice and the principles of currency, and should be of great value to students of banking affairs. At the same time the information supplied is so well arranged that the book will prove of great service to bank officials for matters of reference."-Bankers' Magazine. 
BILLS, CHEQUES, AND NOTES. A Handbook for Business Men and Lawyers. Together with the Bills of Exchange Act, 1882, and the Bills of Exchange (Crossed Cheques) Act, 1906. By J. A. Slater, B.A., LL.B. (Lond.), Barrister-at-Law. In demy 8vo, cloth gilt, 206 pp., 2s. 6d. net.

GUIDE FOR THE COMPANY SECRETARY. A Practical Manual and Work of Reference for the Company Secretary. By Arthur Coles, F.C.I.S. Second Edition, Enlarged and thoroughly Revised. In demy 8vo, cloth gilt, 432 pp., with 75 facsimile forms, and the full text of the Companies Acts, 1908 and 1913, and the Companies Clauses Act, 1845. 5s. net.

"The title is sufficiently explanatory of the contents, but the book constitutes a manual for reference by secretaries of joint stock companies. The work seems to include every branch of secretarial duty, and to be excellently well done." - Money Market Review.

COMPANY ACCOUNTS. By the same Author. (See page 9.)

THE COMPANY SECRETARY'S VADE MECUM. Edited by Philip Tovey, F.C.I.S. A Manual of information on matters relating to Limited Liability Companies, for Directors, Secretaries, etc. Second edition, enlarged and revised. In foolscap Sro, cloth, 247 pp., 2 s. net.

SECRETARY'S HANDBOOK. A Practical Guide to the Work and Duties in connection with the Position of Secretary to a Member of Parliament, a Country Gentleman with a landed estate, a Charitable Institution, with a section devoted to the work of a Lady Secretary and a chapter dealing with Secretarial work in general. Edited by H. E. BLAIN. In demy 8vo, cloth gilt, 168 pp., 3s. 6d. net.

BALANCE SHEETS. How to Read and Understand Them. A Complete Guide for Investors, Business Men, Commercial Students, etc. By Philip Tovey, F.C.I.S. With 26 inset balance sheets. In foolscap 8vo, cloth, 1s. net.

PROSPECTUSES : HOW TO READ AND UNDERSTAND THEM. By the same Author. In demy 8vo, cloth gilt, 1s. 6d. net.

THE TRANSFER OF STOCKS, SHARES, AND OTHER MARKETABLE SECURITIES. A manual of the law and practice. By F. D. HEAD, B.A. (Oxon). Late Classical Exhibitioner of Queen's College, of Lincoln's Inn, Barrister-at-Law. Second edition, revised and enlarged. In demy $8 v o$, cloth gilt, 220 pp., 5s. net.

"The practising secretary is to be congratulated on the addition to his working library of this excellent text-book on one of the most complicated and difficult subjects with which he has to deal. Admirable alike in design and execution, this exposition of the law and the practice relating to the transfer of securities in joint stock companies is a complete and reliable handbonk on transfers, to which the secretary may turn with confidence in the expectation of linding all the difficulties of the subject dealt with, and not slurred over in the far tno usual manner."-The Secretary. 


\section{DICTIONARY OF SECRETARIAL LAW AND PRACTICE.}

A Comprehensive Encyclopaedia of Information and Direction on all matters connected with the work of a Company Secretary. Fully illustrated with the necessary forms and documents. With Sections on special branches of Secretarial Work. Edited by PhilıP Tovey, F.C.I.S. With contributions by nearly 40 eminent authorities on Company Law and Secretarial Practice, including: G. N. Barnes, M.P.; F. Gore-Browne, K.C., M.A.; A. Crew, F.C.I.S. ; J. P. Earnshaw, F.C.I.S. ; M. Webster Jenkinson, F.C.A.; F. W. Pixley, F.C.A. In one handsome volume, half leather gilt, gilt top, 774 pp., 25s. net.

This work makes a very wide appeal It explains in detail the duties and liabilities of a Secretary from the inception of a Company until the completion of its winding up, should such a course be necessary. Each stage in the history of a Limited Company, whether it be private or public, is fully dealt with; every important decision in Company Law has been embodied in the text; and for the benefit of the close student a synopsis of the leading cases is given in a large number of instances. Promoters and Directors will find in the pages of this work much valuable and interesting information. Careful and accurate expositions of their legal position are given, and their duties and liabilities are fully defined. Accountants, Financiers, Shareholders, Managers, and Students of Commerce, and, indeed, all who are directly or indirectly interested in Limited Companies, may consult the Dictionary with confidence on all matters appertaining to Company Law and Administration. Other important branches of the profession have not been overlonked; and adequate treatment bas been given to the duties and responsibilities of Private Secretaries, Lady Secretaries, Secretaries to Trade Uninns. and other organisations.

WHAT IS THE VALUE OF A SHARE? Tables for readily and correctly ascertaining (1) the present value of shares; and (2) what dividends should be paid annually to justify the purchase or market price of shares. By D. W. Rossiter, Head of the Intelligence Department of the Consolidated Gold Fields of South Africa, Ltd. In demy 8vo, limp cloth, 20 pp., 2s. 6d. net.

INCOME TAX AND SUPER-TAX PRACTICE. Including Legislation consequent on the War. By IV. E. SNELLING, of the Inland Revenue Department. In demy $8 \mathrm{vo}$, cloth gilt, $450 \mathrm{pp}$., 10s. 6d. net.

The aim of this book, which is in accordance with the provisions of the Finance Act, 1914, is to provide a lucid and complete guide to the practice of income tax. It opens with concisely stated rules for the preparation and adjustment of accounts for income tax purposes. Succeeding chapters deal with the average system and the circumstances in which it may be departed from, the preparation of returns (including those of single traders, firms and companies), assessments on lands and houses, repayment claims and super-t ax returns and assessments. Then follows an exhaustive dictionary of income tax extending to over 100,000 words, arranged under 400 headings such as Advertisements, Depreciation, Employees, Foreign Traders, Gratuities, Licensed Premises, Plantations, Syndicates, Window Fittings, etc.

"Affords the clearest possible guidance through that amazing labyrinth. It deals in the most lucid way with a multitude of difficulties that constantly arise, it is excellently arranged for ready reference, and it will prove invaluable to business and professional men."-Truth. 
ADVANCED ACCOUNTS. A Manual of Advanced Book-keeping and Accountancy for Accountants, Book-keepers and Business Men. Edited by Roger N. Carter, M.Com., F.C.A., Lecturer on Accounting at the University of Manchester. In demy 8vo, cloth gilt, 988 pp., 5s. net.

"It is a marvel of value for money, is well produced, and the subject-matter, exercises with key, forms, documents and index are all that can be desired. For those preparing for any of the public examinations in advanced book-keeping and accountancy this work is of inestimable value. It should be found on the bookshelf of everyone engaged in business, and requires only to be known to command the sale it justly deserves."-Chamber of Commerce Journal.

AUDITING, ACCOUNTING AND BANKING. By FRANK DOWLER, A.C.A., and E. MARDINOR HARRIS, Associate of the Institute of Bankers. In demy $8 \mathrm{vo}$, cloth gilt, 328 pp., 5 s. net.

"An authoritative book of real practical value. Diagrams, figures and explanations make the auditing part quite clear. Also the author has referred where, necessary, to legal cases. The banking section is lucid and practical, being far clearer than in books which one remembers having studied. It should be in every business or banking library, and would be helpful as a text-book for examinations." -T.P.'s Weeklv.

THE PRINCIPLES OF AUDITING. A Practical Manual for Advanced Students and Practitioners. By F. R. M. DE Paula (of the firm of De Paula, Turner, Lake \& $C$.). ; Fellow of the Institute of Chartered Accountants; Lecturer to the Chartered. Accountant Students' Society of London. In demy 8ro, cloth gilt, 224 pp., 5s. net.

"In the space of nine chapters, and less than 190 pages, Mr. de Paula has compressed an admirably lucid, practical, and well-arranged outline of the general principle of Auditing. We know of no book of similar size which contains so clear and complete an exposition of the subject. The appended 100 questions cover the subject-matter of the volume, and enable the student to test the thoroughness of his reading. We cordially recommend this book to the notice of instructors in accounting in commercial institutes."-Commercial Institutes Staff Gazette.

ACCOUNTANCY. By F. W. Pixley, F.C.A., of the Middle Temple, Barrister-at-Law, Ex-President of the Institute of

Chartered Accountants. In demy 8vo, cloth gilt, 318 pp., 5 s. net.

" The work constitutes a very successful at tempt to treat accountancy on a scientific basis. The author gives valuable advice on the construction of books and statements of account. The work is of a practical nature, and should be of the grearest value and assistance to intending practitioners."-Money Markel Review. "A careful, practical treatise." -Times.

COST ACCOUNTS in Principle and Practice. By A. Clifford

RIDGWAY, A.C.A. In demy 8 vo, cloth gilt, with 40 specially prepared forms, 3s. 6d. net.

"This treatise deals exhaustively with its subject, and discusses the questions involved from the point of view both of principle and practice. Manufacturers especially should find it of great service."-Financial Times.

COMPANY ACCOUNTS. By ARTHUR COLES, F.C.I.S. With a Preface by Charles Comins, F.C.A. In demy 8vo, cloth gilt, 320 pp., 5 s. net.

“ We think Mr. Coles' book is one which will find favour both with practitioners and students. Its clearness and conciseness are commendable, and the author's experience has enabled him to deal with company accounts from a practical as well as a theoretical point of view."-Accountant. 
MANUFACTURING BOOK-KEEPING AND COSTS. By GEORGE Johnson, F.C.I.S. In demy 8 vo, cloth gilt, 120 pp., 3s. 6d. net.

"This is a very valuable and practical work on the accounts and books that a manufacturing establishment should keep .. The book is a very useful one ... we trust that it will receive a hearty and practical welcome."-Commercial Review.

GOLD MINE ACCOUNTS AND COSTING. A Practical Manual for Officials, Accountants, Book-keepers, etc. By G. W. TAIT (of the South African staff of a leading group of mines). In demy 8vo, cloth gilt, 93 pp., 5s. net.

"The author of this book has had many years' practical experience in account keeping on the mines in South Africa, and the method he sets out will be found of considerable use to those keeping accounts of mines of all classes and in all parts of the world."-Capitalist.

THE ACCOUNTS OF EXECUTORS, ADMINISTRATORS AND

TRUSTEES. With a Summary of the Law in so far as it relates to Accounts. By William B. Phillips, A.C.A. (Hons. Inter. and Final), A.C.I.S. In demy $8 \mathrm{vo}$, cloth gilt, 3s. 6d. net.

"The book is very readable, and contains much that is helpful. Those called upon to act as executors, particularly those dealing with estates under English iurisdiction, will find their duties set out very clearly. The various illustrations are clearly set out, and will also be found helpful both to the practitioner and the student."-Accountants' Magazine.

RAILWAY ACCOUNTS AND FINANCE. Railway Companies (Accounts and Returns) Act, 1911. By Allex E. Newhook, A.K.C., Chief Accountant to the London and South-IVestern Railway Company. In demy 8vo, cloth gilt, 148 pp., 5s. net.

"Mr. Newhook writes with inside knowledge of railways, and his exposition of the new Act should be of assistance to all connected with the administration of British railway companies."-Financier.

\section{THE HISTORY, LAW, AND PRACTICE OF THE STOCK} EXCHANGE. By A. P. Poley, B.A., of the Inner Temple and Midland Circuit, Barrister-at-Law; and F. H. Carruthers Gould, of the Stock Exchange. Second edition revised and brought up to date. In demy 8 vo, cloth gilt, $348 \mathrm{pp}$. 5 s. net.

"It is possible to hail with something more than merely passing gratitude on our part, and we trust also on the part of members of the Stock Exchange, a new edition of a work which, on its first appearance, met with a reception commensurate with its merits . . . worth double the price the Publishers ask for it."-Financier.

BANKRUPTCY, DEEDS OF ARRANGEMENT, AND BILIS OF SAlE. By IV. Valentine Ball, M.A., and G. Mills, B.A., both of Lincoln's Inn, Barristers-at-Law. In demy 8vo, cloth gilt, 364 pp., 5s. net. Third Edition, Enlarged and Revised in accordance with the Bankruptcy Act, 1914, and the Deeds of Arrangement Act, 1914.

"Mr. Ball has elucidated an abstruse subjert so clearly that the non-expert may consult with understanding and profit, but he has also kept in riew the special requirements of chartered accountants."-Financier. 
MERCANTile LaW. By J. A. Slater, B.A., Ll.B. A practical exposition for Law Students, Business Men, and Advanced Classes in Commercial Colleges and Schools. Second Edition, Revised. In demy 8 vo, cloth gilt, 448 pp., 5 s. net.

"We are not surptised that a secunu edition should have been called for. Business men will find it a book of reference which will provide them with the rules of law upon general subjects in a short and clear form, and the law student, 100, will find it of considerable assistance."-Law Times.

HANDBOOK OF LOCAL GOVERNMENT LAW. Speciaily designed for all engaged in the offices of Local Authorities in England and Wales, and for Public Men. By J. WVells Thatcher. Of the Middle Temple, Barrister-at-Law. In crown 8vo, cloth gilt, 250 pp., 3s. 6d. net.

ENCYCLOPAEDIA OF MARINE LAW. By LAWRENCE DUCKwORTH, of the Middle Temple, Barrister-at-Law. Second Edition, Revised. In demy 8vo, cloth gilt, 386 pp., 5s. net.

"The object of this volume is to place before a shipowner or anyone connected with maritime commerce, in well-digested form, the essence of the law and the full meaning of words connected therewith. The advantage of such lucid condensation of a library of books in a single volume will, we venture to believe, be appreciated by busy men of commerce."-Shipping World.

GUIDE TO THE LAW OF LICENSING. The handbook for all Licence-holders. By J. Wells Thatcher, Barrister-at-Law. In demy 8vo, cloth gilt, 200 pp., 5s. net.

This guide has been specially written for the use of licence-holders. The various subjects are treated in alphabetical order, and will be found easy for instant reference. The alphabetical arrangement of the titles will be of service, both to "The Trade," and to the trained minds of the legal profession, for it gives a short and accurate summary of each subject of the law of licensing.

RAILWAY (REBATES) CASE LAW. By Geo. B. LisSenden, Author of "Railway Trader's Guide," etc., etc. In demy 8vo, cloth gilt, 450 pp. 10s. 6 d. net.

"Mr. Lissenden has done a great service. . Any satisfactory report of these complicated cases before the Railway and Canal Commission must necessarily go into considerable detail, and this book supplies it, thereby saving the inquirer much trouble and expense hy concentrating them in one volume."-Railway Gazette.

THE LAW RELATING TO THE CHILD : Its Protection, Education, and Employment. With Introduction on the Laws of Spain, Germany, France, and Italy; and Bibliography. By Robert IV. Holland, M.A., M.Sc., LL.D., of the Middle Temple, Barrister-at-Law. In demy $8 \mathrm{vo}$, cloth gilt, 166 pp., 5 s, net.

"Dr. Holland has done much in this book to bring together the loose ends which have been creatcd by the various Acts of Parliament affecting Children's Education, Birth, Notification, School Feeding, and so on."-Law Time's.

HOUSEHOld LAW. By J. A. Slater, B.A., LL.B. (Lond.). In demy 8 vo, cloth gilt, 316 pp., 5 s. net.

"The scheme of this book is quite admirable. It covers almost every phase of a householder's existence, and continues it even to the winding up of his estate."

- Morning Post. 
COMPANIES AND COMPANY LAW. Together with the Companies (Consolidation) Act, 1908, and the Act of 1913. By A. C. Connell, LL.B. (Lond.), of the Middle Temple, Barristerat-Law. In demy 8 ro, cloth gilt, 348 pp., 5s. net.

"The volume before us will afford great assistance to all persons who are at any time brought into contact with joint stock companies. The numerous points of company law will be found to be lucidly explained, and copies of all the more important forms are set out."-Law Times.

COMPANY CASE LAW. By F. D. HeAD, B.A. (Oxon.), Late Classical Exhibitioner of Queen's College ; of Lincoln's Inn, Barrister-at-Law. In demy $8 \mathrm{vo}$, cloth gilt, 314 pp., 7s. $6 \mathrm{~d}$. net.

The book also contains an indexed copy of the Colnpanies Acts, 1908 and 1913, and the Forged Transfers Acts, 1891 and 1892.

"The book should be of considerable use to directors and all concerned in joint stock companies, as well as to students for examination in company law." - Law rimes.

THE LAW OF CARRIAGE. By J. E. R. Stephens, B.A., of the Middle Temple, Barrister-at-Law. In demy 8vo, cloth gilt, 324 pp., 5s. net.

"It deals with the subject in a clear, concise manner, and should undoubtedly appeal to those persons for whom it is intended. Practically the whole of the cases on this branch of the law are referred to in the volume."-Law Times.

\section{INCOME TAX, SUPER-TAX, AND INHABITED HOUSE DUTY}

LAW AND CASES. A Practical Exposition of the Law, for the use of Income Tax Officials, Solicitors, Accountants, etc. With an Analysis of the Schedules, Guide to Income Tax Law, and Notes on Land Tax. Including Legislation consequent on the War. By W. E. Snelling, of the Inland Revenute Department. New Edition, Enlarged and thoroughly Revised in accordance with the Finance Act of 1914. In demy 8vo, cloth gilt, 432 pp., 10s. 6d. net.

- Mr. Snelling has done his work as compiler extremely well The numerous sections are models of clearness and brevity, while in most instances they are illustrated and supported by references to the decisions of high legal authorities upon the particular points concerned."-Morning Post.

\section{THE LAW RELATING TO SECRET COMMISSIONS AND BRIBES} (CHRISTMAS BOXES, GRATUITIES, TIPS, ETC.) THE PREVENTION OF CORRUPTION ACT, I906. By ALBERT CREw, of Gray's Inn, and the South Eastern Circuit, Barristerat-Law ; Lee Prizeman of Gray's Inn ; author of " A Synopsis of Mercantile Law," "Company Law," etc. In demy 8vo, cloth gilt. 5s, net.

"It is an admirable summary of the law before and after the passing of the Prevention of Corruption Act, 1906 , with an excellent analysis of the Act and full reference to cases. It is a very good handbook of its kind. The exposition is clear and refercnce is easy." - Westminster Gazctte. 
THE LAW OF REPAIRS AND DILAPIDATIONS. By T. CATO

WORSFOLD, M.A., LL.D. In crown 8vo, cloth gilt, 3s. 6 d. net.

"Within less than a hundred pages he gives a very clear statement of the law, not only as between landlord and tenant, but also in the case of ecclesiastical dilapidations and of repairs to settled property; and Chapter VII contains a useful outline of the transference of the rights and liabilities in regard to repair to successors in title of the lessor and lessee. . . . The book is concise and practical." Solicitor's Journal.

THE LAW OF EVIDENCE. By W. Nembhard Hibbert, LL.D. (Lond.), Barrister-at-Law of the Middle Temple. Second edition revised. In crown 8vo, clotll gilt, 126 pp., 3s. 6d. net.

"Mr. Hibbert, having had many years' experience in preparing students for legal examinations, is well qualified to write such a book as this. . . In five concise chapters he gives the elementary knowledge necessary, at the sane time referring his readers to the important works on the subject."--Iaw' Times.

THE LAW OF PROCEDURE. By the same Author. In crown 8vo., cloth gilt, 122 pp., 5s, net.

The object of this work is to present in as concise and simple a form as possible a complete treatment of the subject, including the details of the various Courts and their jurisdiction. While the work is primarily intended for law students at the Universities, the Inns of Court, and the Law Society, it will also prove of use to the practitioner.

THE WORLD'S COMMERCIAL PRODUCTS. A descriptive account of the Economic Plants of the World and of their Commercial Uses. By W. G. Freeman, B.Sc., F.L.S., Superintendent, Colonial Economic Collections, Imperial Institute, London, and S. E. Chandler, D.Sc., F.L.S., Assistant, Colonial Economic Collections, Imperial Institute, London. With contributions by numerous Specialists. In demy 4 to, cloth gilt, 400 pp., 420 illustrations from photographs and 12 coloured plates and maps, 10s. 6d. net.

DICTIONARY OF THE WORLD'S COMMERCIAL PRODUCTS. With Equivalents in French, German, and Spanish. Second Edition, Revised. In demy 8vo, cloth gilt, 164 pp., 2s. 6d.

\section{A NEW DICTIONARY OF THE PORTUGUESE AND ENGLISH} LANGUAGES. Based on a manuscript of Julius CORNET, by H. Michaelis. In two Parts. First Part: Portuguese-English. Second Part : English-Portuguese. Colloquial, commercial, and industrial terms have been plentifully introduced throughout the book and irregularities in the formation of the plural and in the conjugation of verbs have been carefully noted. Second Edition. Two volumes, each 15 s. net. 


\section{ABRIDGED DICTIONARY OF THE PORTUGUESE AND ENGLISH LANGUAGES. Including Technical Expressions of Commerce and Industry, of Science and Arts. By H. Michaelis. In crown $8 \mathrm{vo}$, cloth, 15 s. net. \\ The present Dictionary is an abridgment of the author's larger Portuguese and English Dictionary, its whole construction and principal features being the same as those of the larger work. In two Parts. I. Portuguese-English. English- Portuguese. Both Parts in one vol.}

\section{DICTIONARY OF COMMERCIAL CORRESPONDENCE IN FRENCH, GERMAN, SPANISH, AND ITALIAN. Second Revised, and cheaper Edition. In demy 8vo, cloth, 502 pp., 5s. net. \\ "Nine hundred columns are occupied by the dictionary, and in an appendix of more than fifty pages we have specimen letters dealing with the most important phases of commercial life. They are practical models which can easily be adapted. Care has been taken throughout to give the student the essentials of a good style of commercial correspondence in a clear and helpful fashion, and as a work of reference the volume is invaluable."-Manchester Courier.}

\section{SPANISH-ENGLISH AND ENGLISH-SPANISH COMMERCIAL} DICTIONARY of the words and terms used in commercial correspondence which are not given in the dictionaries in ordinary use; compound phrases, idiomatic and technical expressions, etc. By G. R. Macdoxald, Society of Arts' First Prizeman and Silver Medallist for Spanish, etc.; Lecturer in Spanish at the Municipal School of Commerce, Manchester. In crown Svo, cloth gilt, 652 pp., 7s. 6d. net.

CONSULAR REQUIREMENTS FOR EXPORTERS AND SHIPPERS TO ALL PARTS OF THE WORLD. BY J. S. Nowery. In crown 8vo, cloth. With exact copies of all forms of Consular Invoices. 2s. 6d. net.

THE THEORY AND PRACTICE OF ADVERTISING. By WALTER Dill ScotT, Ph.D. In large crown 8vo, cloth, with 61 illustrations, $240 \mathrm{pp} ., 6 \mathrm{~s}$. net.

The Author of this work has made advertising the study of his life and is acknowledged as one of the greatest authorities on the subject in the United States.

THE PSYCHOLOGY OF ADVERTISING. A Simple Exposition of the Principles of Psychology and their Relation to Successful Advertising. By the same Author. In large crown 8vo, cloth, with 67 illustrations, $282 \mathrm{pp}$., 6 s. net.

In this book, Professor Dill Scott does not merely state principles and theorize upon them-he furnishes characteristic examples and appropriate illustrations in explanation and support of his views.

THE PRINCIPLES OF PRACTICAL PUBLICITY. "The Art of Advertising." By Truman A. De IVEese. In large crown 8vo, cloth, with 43 full-page illustrations, 266 pp., 7s. 6d. net.

The book will be found a comprehensive and practical treatise covering the subject in all its branches, showing the successful adaptation of advertising to all lines of business. 
ADVERTISING AS A BUSINESS FORCE. A Compilation of Experience Records. By P. T. Cherington, Instructor in Commercial Organisation in the Graduate School of Business Administration, Harvard University. In demy 8vo, cloth gilt, 586 pp., 7s. 6d. net.

“ Prof. Cherington's book is incomparably the best and most authoritative work on the general subject of advertising that has yet been issued. Here, at last, we have a book that represents advertising in the way its most advanced exponents see it, that illustrates it with instances drawn from the field of actual occurrences." "Printers' Ink" (U.S.A.).

THE PRINCIPLES OF ADVERTISING ARRANGEMENT. By F. A. PARsons, President of the New York School of Fine and Applied Art. Size 7 in. by $10 \frac{1}{4}$ in., cloth, 128 pp., with many illustrations. 6s. net.

" We can cordially recommend all concerned with the creative side of advertising to read this book, which is in many respects invaluable."-Adrcrtiscr's Wcckly.

ADS AND SALES. A study of Advertising and Selling from the standpoint of the new principles of Scientific Management. By Herbert N. Casson. In demy 8vo, cloth, 6s. net.

" This is the most fascinating book on advertising since the appearance of Professor W. D. Scott's 'Theory and Practice of Advertising.' Philosophy and anecdote are cleverly interwoven.... the Author has analysed no less than 8,000 advertisements and divided them into twenty-five different classes."-Advertising.

PRACTICAL SALESMANSHIP. A treatise on the Art of Selling Goods. By N. C. Fowler, Jnr. Assisted by twenty-nine Expert Salesmen, Sales managers, and prominent business men In crown $8 \mathrm{vo}$, cloth, $337 \mathrm{pp} ., 3 \mathrm{~s}$. $6 \mathrm{~d}$. net.

COMMERCIAL TRAVELLING. A Guide to the Profession for present and prospective Salesmen "on the road." By ALBERT E. Bull. In crown 8 vo, cloth gilt, 2 s. 6 d. net.

SYSTEMATIC INDEXING. By J. KAISER. In royal 8vo, cloth gilt, with 32 illustrations and 12 coloured plates. 12s. $6 \mathrm{~d}$. net.

" Every bit of his book is worth reading; he not only shows what should be done, but why it should be done, and the reason that some other method should not be adopted. He gives very frequent illustrations to amplify his text, and a careful perusal of his views will enable the ordinary business man to quickly seize upon the essentials in useful indexing."-Liverpool Journal of Commerce.

TELEGRAPH CIPHERS. By A. W. E. Crosfield, Assoc. Municipal School of Commerce, Manchester. Size, 12 in. by 12 in., cloth, 21s. net.

A condensed vocabulary of 101 Million pronounceable artificial words all of ten letters, and with a difference of at least two letters between each half-word of five letters. 


\section{THE "COLE " CODE, OR CODE DICTIONARY. Size $7 \frac{1}{2}$ in. by} 10 in., 272 pp., cloth. 15s. net.

This book contains a simple, safe, and economical method of cabling verbatim commercial, technical, and social messages, complete and up to date, with unlimited facilities for extensions to suit any kind of business, including cabling from books, catalogues, price lists, etc. There are also two extra vocabularies of $10,000,000$ words each, arranged in alphabetical and numerical order.

ECONOMIC GEOGRAPHY. By J. McFarlane, M.A., M.Com., Lecturer in Geography in the University of Manchester. In demy 8 ro, cloth gilt, 568 pp., with 18 illustrations, 7s. 6d. net.

"Every portion of the habitable globe is dealt with systematically and thoroughly, and the result is not only a text-book of the highest educational value, but a most interesting and instructive volume, which will appeal to the ordinary reader in search of reliable information about the world he lives in, as well as to the teacher and student. It is no exaggeration to say that it is the most important work on Economic Geography that has yet been published."-Aberdeen Daily Journal.

\section{OUTLINES OF THE ECONOMIC HISTORY OF ENGLAND.}

Study in Social Development. By H. O. Meredith, M.A., M.Com., Fellow of King's College, Cambridge; Professor of Economics, Queen's University, Belfast. In demy 8vo, cloth gilt, 376 pp., 5 s. net.

"Beginning with the Economic development of Britain during the Roman occupation, the work traces the progress made down to the present day, in the course of which Mr. Meredith discusses such interesting subjects as the genesis of capitalism, money and taxation, the growth of trade and industry, the trade union movement. the law and the wage-earning classes, finance and national welfare, etc. To the student and busy man it affords an excellent introduction to the study of one of the most complex questions of the day."-Chamber of Commerce Journal.

INDUSTRIAL TRAFFIC MANAGEMENT. By GEO. B. LISSENDEN, Author of "Railway (Rebates) Case Law," etc., etc. With a Foreword by Charles E. Musgrave, Secretary, London Chamber of Commerce. In demy 8vo, cloth gilt, 260 pp., 7s. 6d. net.

This new work by Mr. George. B. Lissenden, who is a well-known authority on the subject, is a thoroughly practical guide, and deals fully and comprehensively with the subject in all its many branches. No one who has to deal in any way with the conveyance of goods by rail, canal, road, or coastwise, will fail to obtain a thorough grasp of the subject of industrial traffic management if he carefully follows the directions contained in Mr. Lissenden's book.

\section{THE HISTORY AND ECONOMICS OF TRANSPORT. By}

Adam W. KIRKaldy, M.A., B.Litt., Oxford; M.Com., Birmingham; Professor of Finance in the University of Birmingham; and AlFRed Dudley Evans, Secretary of the Birmingham Exchange. In demy 8 vo, cloth gilt, 348 pp., 7s. 6 d. net.

This important volume is of very great interest and value to all whose daily a ffairs bring them into contact with the problems of transport. The book deals, by way of introduction, with methods of transport and their development. Attention is then given in Part I to the Railway in the United Kingdon and Abroad. Part II deals with Railway and Canal Economics. In the final section of the work, Shipping and Ocean Transport problems are discussed, and a very suggestive chapter on the Economics of Marine Fuel is included. Fifteen most useful appendices and a full index complete a work which is a most exhaustive and reliable publication on this important econnice subject. 



\section{University of California \\ SOUTHERN REGIONAL LIBRARY FACILITY \\ 305 De Neve Drive - Parking Lot 17 - Box 951388 \\ LOS ANGELES, CALIFORNIA 90095-1388}

Return this material to the library from which it was borrowed.

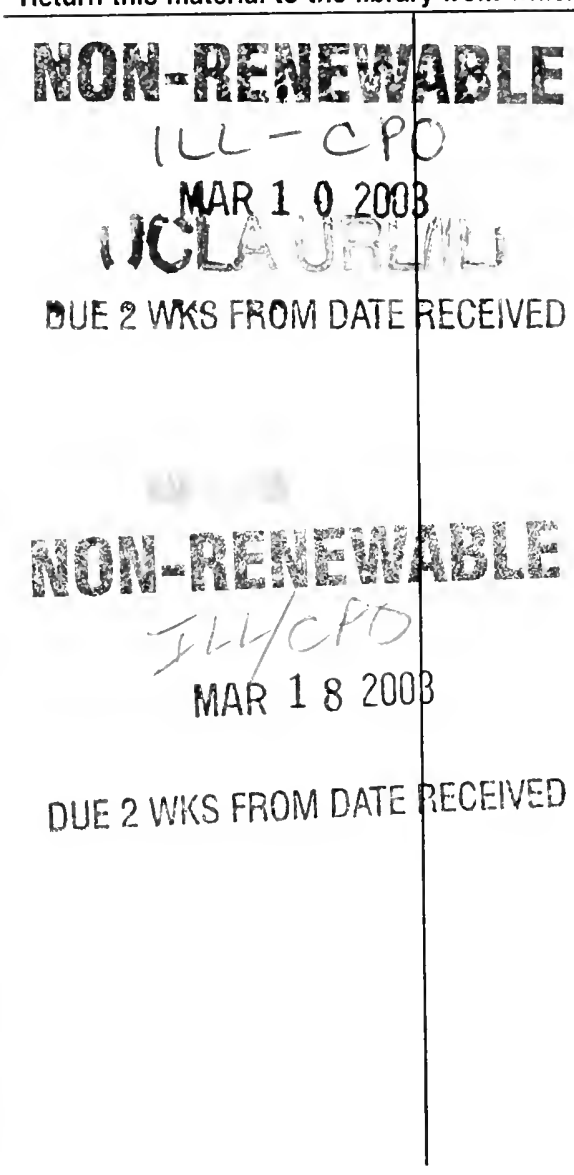


3851 Spalding -

S73f Foreign

exchange.

HG

3851

S73f 
